Please do not destroy or throw away this publication. If you have no further use for it write to the Geological Survey at Washington and ask for a frank to return it

UNITED STATES DEPARTMENT OF THE INTERIOR

Harold L. Ickes, Secretary

GDOLOGICAL SURVEY

W. C. Mendenhall, Director

Water-Supply Paper 773-E

\title{
THE NEW YORK STATE FLOOD \\ OF JULY 1935
}

BY

HOLLISTER JOHNSON

Prepared in cooperation with the Water Power and Control Commission of the Conservation Department and the Department of

Public Works, State of New York

Contributions to the hydrology of the United States, 1936

(Pages 233-268)

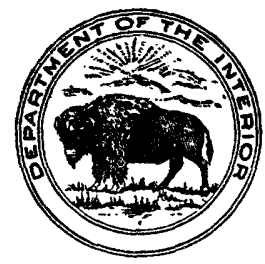

UNITED STATES

GOVERNMENT PRINTING OFFICE

WASHINGTON : 1936

For sale by the Superintendent of Documents, Washington, D. C. - - - - - - - Price 15 cents 



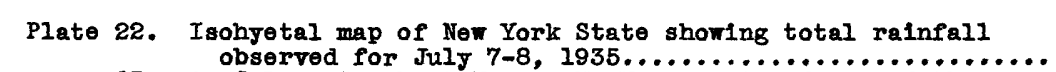

23. A, Salmon Creok at Myers, $\mathbb{K}_{\text {. }} \mathrm{Y}_{\text {. }}$ showing force of the flood waters; $B$, Inundation from Chenango River,

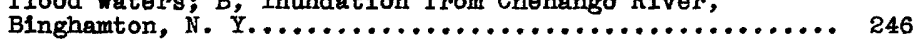

24. Slope-area reach on Gien Creek near Townsend, N. $_{\ldots} \ldots \ldots \ldots$

25. Slope-area reach on Glen Creek near Watkins Glen, $\mathrm{N}$. $\mathrm{Y} . \ldots$

26. Map, profile, and sections of slope-area reach on Glen

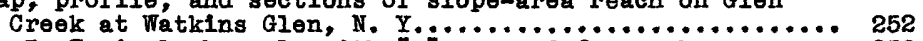

27. $A, B$, Typical channels with $n_{n}$ as sumed for each.........

28. A, B, Typical channels with " $n^{n}$ assumed for each...........

29. Map of Ner York State showing location of flood

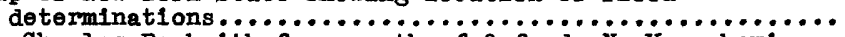

30. A, Charles Beckith farm south of oxford, $N_{\text {. }}{ }_{\text {. }}$, showing typical damage by stones and gravel transported by small streams; $B$, Stone House farm, near Nomich, N. $Y_{.}$, showing typical debris carried by smali streams..........

31. A, Washout of roadbed, Lehigh Valley Railroad; B, New York Central Rallroad at Watklns Glen, N. Y., showing high bridge over Glen Creek destroyed during the flood.......

32. A, Erie Rallroad at Hormell, N. Y., showing roundhouse and equipment buried under flood maters; B, Lackawanna Railroad near Bath, $N$. $Y_{.}$, showing typical flood conditions.

33. A, Taughannock Falls State Park, N. Y., showing destruction of road due to inadequacy of bridge to carry flood waters; $B$, Destruction wrought by flood along Taughan-

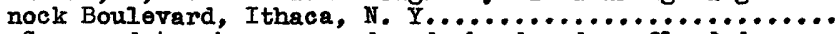

34. A, Cars and tracks marooned and abandoned on fiooded 3 .

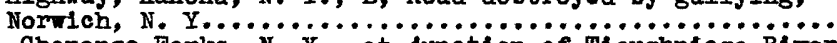

35. A, Chenango Forks, $\mathrm{N}$. $\mathrm{Y}_{\text {, }}$ at junction of Tioughnioga $\mathrm{River}$ and Chenango River, showing Inadequacy of bridge over Tioughnioga River to carry flood waters; B, Inadequacy of Seneca Street Bridge over Canacadea Creek, Hornell, N. $Y$., to carry flood debris...................... 
Plate 36. A, O'Day house on Front Street, Binghamton, N. Y., toppling into the flood waters of Chenango River;

37. A, Inundation of homes and buildings, Horneli,,$\ldots \ldots \ldots$ $B$, Telephone pole driven through side wall and ceiling into the second floor of a home on River street, Hornell, $N, \mathrm{Y} . \ldots \ldots \ldots \ldots \ldots \ldots \ldots \ldots \ldots \ldots \ldots \ldots \ldots \ldots \ldots \ldots . \ldots \ldots$

$\underline{\text { Page }}$ , Inoculation of residents against typhoid fever, Horneli, N. Y.; B, Hazardous situation from which threo people providentially escaped, Smithville Flats, N. Y......... 264

Figure 20. Hydrographs of discharge at points in the Susquehanna River and Chemung River Basins, $N$. Y.............. 247

21. Hydrographs of discharge at points in the Lake ontario, Delawure River, Esopus Creek, and Schoharie Creek

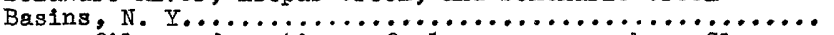

22. Map, profile, and sections of siope-area reach on Gien

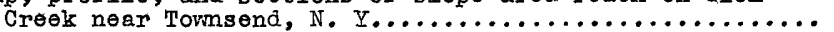


By Hollister Johnson

\section{INTRODUCTION}

A vivid impression of the tragic flood that swept over southern and central New York July 7 and 8, 1935, is furnished in the following quotation from the Albany Evening News for December 26, 1935, in which the outstanding news items of the year were summarized:

Floods leading Finpire state news during 1935

As headlines that flashed across front pages in 1935 recede into memory ith the passing year, one New York state news story stands out above all others--the disastrous July flood in the Southern Tier. Greatest news event of the jear, it also was one of the biggest stories in' Empire State history.

On Sunday, July 7 , sullen clouds hovered motionless above a populace mindful only of vacation plans and escape from oppressive heat. Without warning came torrents of rain--sheets of flowing water down grassy hillsides.

Governor Lehman began a tour of the flood zone the following Thursday. The water had receded and he found:

Dead, 43; homeless, hundreds; estimated damage, $\$ 25,000,000$; devastated, a farm belt 200 miles long, from Hornell to the Catskill Mountains, 50 to 75 miles wide, from Pennsylvania border to the Mohawk Valley.

State and local health officials quickly controlled a mosquito plague in the wake of the flood; prevented a dreaded outbreak of disease. Trying to undo the damage presented a problem that st1li remains for 1936 to solve--rich farm lands in Southern Tier counties buried under rock and gravel, highways ruined, homes destroyed.

The Geological Survey has no means of checking the accuracy of the item of estimated damage, but it is evident that this and the other recorded results mark this flood as a major disaster. Such a disaster can probably never be completely prevented, but by appropriate control and protective measures the resulting losses can be greatly reduced. This report records information about the very unusual precipitation and the consequent flood discharges, which were the most intense in the history of the state. The record of rates of flood discharge actually attained should furnish a basis for more intelligently determining the magnitude of floods to be guarded against, both in the region in which these floods 
occurred and in other regions where the information may be applicable, and thus tend to reduce flood losses.

A flood-control survey of the flood areas in southern and central New York has been made under the direction of the Corps of Engineers, J. S. Army, and it is expected that their findings and recommendations on the problem of flood control in these areas will be presented soon for the consideration of Congress.

\section{ACKNOWLEDGMENTS}

This report was prepared as a part of the regular stream-gaging work in New York, which is conducted under the direction of Arthur W. Harrington, district engineer, Albany, N. Y., and in cooperation with the Water Power and Control Comission of the Conservation Department, Lithgow Osborne, chalrman, and Friend P. W1111ams, secretary, and the Department of Public Works, Frederick Stuart Greene, superintendent.

The writer was in immediate charge of the collection of field data, office computations, and the preparation of this report and was assisted by the members of the district office of the United States Geological Survey at Albany. The final preparation of the data for the report was made with the advice and guidance of $R$. W. Davenport, chief of the division of water utilization.

Fleld assistants were furnished by the Flood Control Survey, Corps of Engineers, U. S. Army, Capt. Lester W. Rhodes, in charge, and the New York State Department of Public Works, Hormell division, W. 0. Dempster, division engineer.

The chapter on the causes of the storm was written by C. I. Mitchell, principal meteorologist, United States Weather Bureau, Washington, D. C.

The discussion of the general features of the storm was written by John C. Fisher, meteorologist, United States Weather Bureau, Ithaca. The section on storms and floods in the Susquehanna River Basin in the vicinity of Binghamton was abstracted from an unpublished article by T. E. Reed, meteorologist in charge, and H. K. Gold, observer, United States Weather Bureau, Binghamton.

Wherever speclal data have been used, individual ackowledgments are given at appropriate places in the report. 


\section{RAINFAII}

\section{Causes}

By C. L. Mitchell

The heavy rains were due, not to any single cause, but to a combination of causes. At 8 p.m. July 3 a well-defined disturbance was movIng eastward over the Hudson Bay region, and an 1ll-defined, slow-moving disturbance over the Rocky Mountain region and the Plains States. At the same time a mass of polar alr had begun to move southward over northern Canada. During the next 24 hours the northern disturbance had moved rapidly east-southeastward to the lower St. Lawrence Valley, the western disturbance had assumed more definite form and was central over South Dakota, and the polar continental air had overspread the Hudson Bay region. By the morning of July 5 the center of the northeastern disturbance was over the Gulf of St. Lawrence and the Dakota disturbance was over Minnesota and extreme western Ontario, moving northeastward. However, 1ts further advance in that direction was blocked by a wedge of the polar continental air that had by this time pushed southeastward over James Bay and northern Ontario. With the center of the northerm highpressure area still west of Hudson Bay, the disturbance was not merely blocked in its northeastward movement but was carried along by the general drift of the upper air toward the east-southeast until the mornIng of July 7, when the center was near Buffalo, N. Y. Meanwhile the front of the polar continental afr mass, which had reached northern New England and extreme northern New York by the evening of the 5th, pushed southward and southwestward, and at $8 \mathrm{p.m}$. of the 7 th this cold front extended from a point a short distance south of New Haven, Conn., northwestward to Lake Ontario, through or very close to the area over which excessive rain was then falling and continued to fall through the night. For the second time the disturbance was blocked, and it made no further eastward progress; but its center drifted slowly southward during the next 24 hours and merged with another disturbance that moved northeastward from Georgla to the New Jersey coast, where it was centered the evening of July 8 . Owing to this umusual meteorologic situation a mass of warm and very molst tropical maritime air moved north-northwestward over eastern and central New York, while at the same time a mass of 
polar continental alr was moving southeastward over the Lake region and 1ts front had reached eastern Lake Erle by $8 \mathrm{p.m.} \mathrm{of} \mathrm{the} 7 \mathrm{th}$. The 1nevitable result was that for a period of many hours, by the physical processes of convergence and forced convection, the continuous stream of tropical marltime air was lifted rapidly; and heavy and prolonged rainfall occurred over a considerable area, of which Cortland appeared to be the center. Wherever the tropical marltime alr mass was forced to rise over elevated areas the rainfall was naturaliy even heavier than over other sections where the wind was not up-slope.

\section{General features}

By John C. F1sher

Past records show that the maximum 1-, 2-, and 3-day rainfalls for stations in south-central New York have been rather evenly divided between those caused by general fall storms and those caused by sumer thunderstorms.

During the period July 6 to 9, 1935, heavy thunderstorms occurred over an area extending from northern steuben County eastward to northern Delaware County, and previous records for 24-, 48-, and 72-hour precipitation were exceeded at all stations.

The records of the Weather Bureau station at Ithaca Indicate that two thunderstorms were observed on the 6 th, seven on the 7 th, and two on the 8th. Commonly but one heary thunderstorm passes over a given locality during a rain perlod; occasionally a second storm follows closely the course of the first, before mun-off bas taken place, and then local damage frequently occurs. But when a succession of storms continues for many hours, then great destruction is a foregone conclusion.

As indicated by the isohyetal map, the distribution of rainfall was unusually uniform for thunderstorm precipltation, but naturally there was considerable variation in amount. Observations throughout this area Indicate that although a few sections escaped serious damage, in others the rainfall was undoubtedly much heavier than recorded by any of the standard gages.

The only tipping-bucket rain gage in the area of maximum rainfall is located at Ithaca. The record of this gage, which shows the time of fall of each 0.01 inch, is therefore of considerable interest. 
Previous records of severe thunderstorms show greater intensities for all periods from 5 minutes to 2 hours; if this record is indicative of conditions throughout the area, the rainfalls were not of the type commonly characterized as "cloudbursts"; in other words, although the amount of precipitation falling in 24 hours, 48 hours, and 72 hours exceeded all previous records, the rate of fall was at no time unprecedented.

Comparison of greatest recorded precipitation, in inches, for 24-, 48-, and 72-hour periods, at stations in south-central New York (Prepared by U. S. Weather Bureau, Ithaca, N. Y.)

\begin{tabular}{l|c|c|c|r|r|r|r}
\hline & \multirow{2}{*}{$\begin{array}{c}\text { Length } \\
\text { of } \\
\text { record }\end{array}$} & \multicolumn{2}{|c|}{24 -hour } & \multicolumn{2}{c|}{48 -hour } & \multicolumn{2}{c}{72 -hour } \\
\cline { 3 - 8 } Station & (jears) & 1935 & Previous & 1935 & Previous & 1935 & Previous \\
\hline Ithaca & 77 & 7.90 & 4.70 & 9.25 & 5.88 & 9.50 & 5.96 \\
Cortland & 57 & 7.67 & 5.80 & 10.58 & 6.47 & 11.15 & 7.82 \\
Norwich & 29 & 6.10 & 4.04 & 9.07 & 4.94 & 9.56 & 5.25 \\
Delhi & 22 & 8.52 & 5.71 & 8.68 & 6.44 & 9.43 & 6.49 \\
Haskinville & 36 & 3.35 & 2.80 & 6.70 & 3.61 & 6.76 & 4.25 \\
Oneonta & 41 & 5.24 & 5.09 & 6.71 & 5.18 & 6.94 & 5.26 \\
Burdett & 3 & 8.50 & - & 10.50 & - & 11.10 & - \\
Ovid & 3 & 7.61 & - & 9.84 & - & 10.61 & - \\
Hammondsport & 3 & 6.10 & - & 8.00 & - & 8.47 & - \\
\hline
\end{tabular}

\section{Rainfall records}

The daily weather maps of the United States Weather Bureau are avallable for those who may wish to study carefully the development and progress of the July storm. In this report rainfall is the only meteorologic feature of the storm that will be presented. The information contained herein has been compiled from sources that are believed to be reliable, and it is assembled as a means of preserving a record of this outstanding storm.

No offlcial records were made of the greatest and most intense rainfall that occurred. The heaviest rainfall was apparently centered along an approximately east-west line extending from a point near Homell, in Steuben County, to a point near Delhi, in Delaware County. There were also heavy rains in other more or less isolated sections of the State, as In the Mohawk Valley; near Chaumont, Jefferson County; near Glens Falls; and in certain portions of the Catskill Mountains. 
Records of precipitation have been obtained from the United States Weather Bureau and other indicated sources and are shown in the table of "Daily and maximum 2-day rainfall, in inches." The figures are the amounts as reported by the observers and are not strictly comparable, as the times of the observations at the various stations were not simultaneous. The amount as recorded usually represents the rainfall for the 24-hour period preceding the time of observation. Rainfall measured in the morning may be recorded under the date of measurement or under the date of the preceding day. Rainfall occurring during the daylight hours will probably be recorded under the date of occurrence at a station where observations are made in the late afternoon but may be recorded under the date of occurrence or under the date of the following day at a station where observations are made in the early morning.

The records at the stations having automatic rain gages indicate that most of the precipitation that caused the flood occurred during a 24-hour period commencing generally in the late aftermoon of July 7 . Because of variations in the methods of the observers in recording their measurements, and the fact that ine period of the storm covered parts of two observation periods, it is belleved that the recorded maximum 2-day rainfall represents very closely the rainfall which generally caused the flood and a large part of which probably occurred within a perlod of about 24 hours. The isohyetal map on plate 22, prepared by John 0 . F1sher, meteorolog1st, United States Weather Bureau, Ithaca, shows the total rainfall recorded under the dates of July 7 and 8 at stations reporting to the United States Weather Bureau at Ithaca. Supplemental measurements of the rainfall made after the storm indicate that a much heavier precipltation than that shown on the map probably occurred over a large area. 


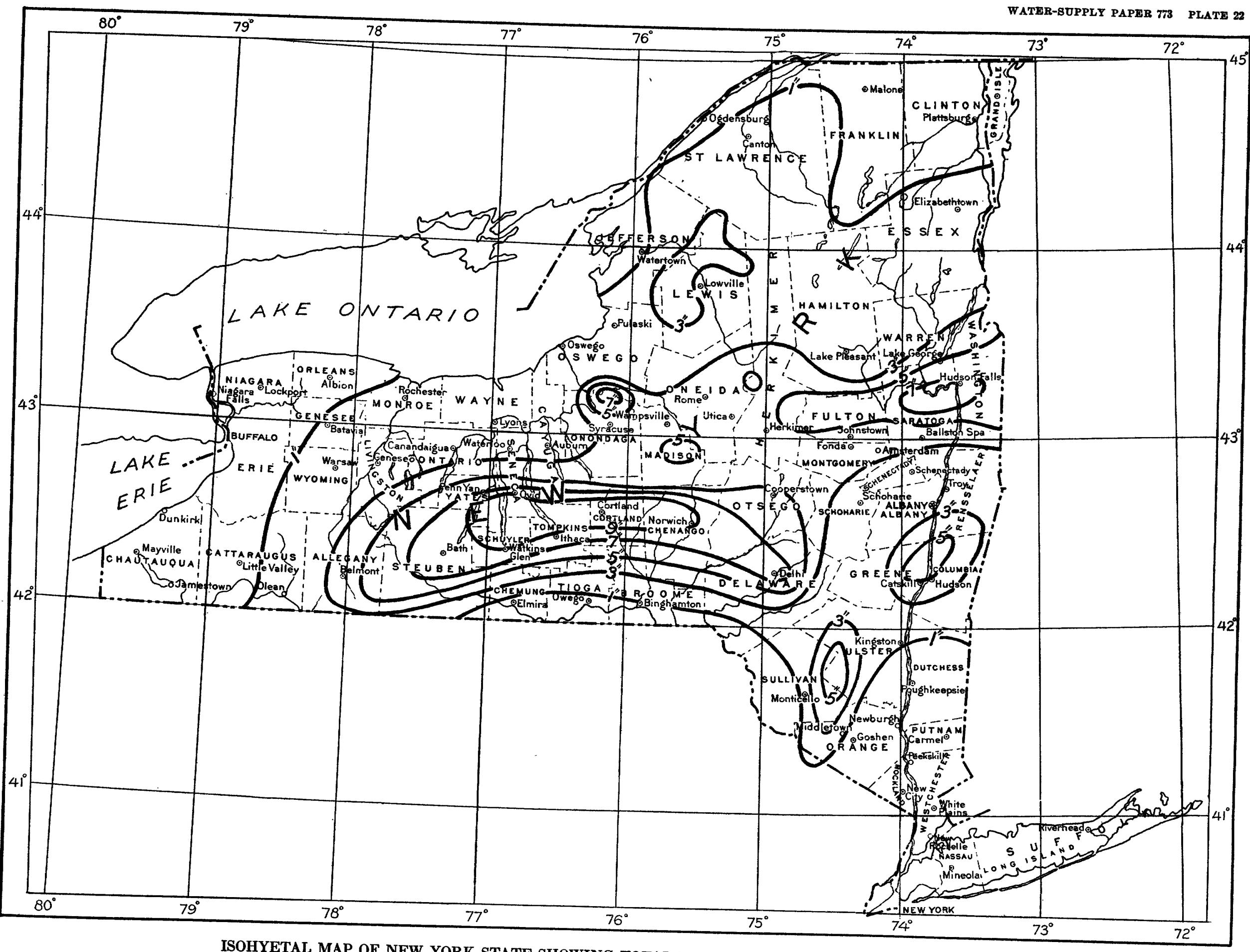

ISOHYETAL MAP OF NEW YORK STATE SHOWING TOTAL RAINFALL OBSERVED FOR JULY 7-8, 1935. 
Daily and maximum 2-day rainfal1, in inches

\begin{tabular}{|c|c|c|c|c|c|c|c|}
\hline \multirow{2}{*}{ Station } & \multirow{2}{*}{ County } & \multicolumn{5}{|c|}{ July } & \multirow{2}{*}{$\int_{2-\mathrm{day}}$} \\
\hline & & 6 & 7 & 8 & 9 & 10 & \\
\hline \multicolumn{8}{|l|}{ Western Plateau } \\
\hline $\begin{array}{l}\text { Alfred } \\
\text { Allegany State Park } \\
\text { Andover } \\
\text { Angelica } \\
\text { Arnot (a) } \\
\text { Caneadea Dam } \\
\text { Elmira } \\
\text { Franklinville } \\
\text { Haskinville } \\
\text { Lost Nation Brook (b) } \\
\text { Olean } \\
\text { Sclo } \\
\text { Woodhull }\end{array}$ & $\begin{array}{l}\text { Allegany } \\
\text { Cattaraugus } \\
\text { Allegany } \\
\text { Allegany } \\
\text { Schuyler } \\
\text { Allegany } \\
\text { Chemung } \\
\text { Cattaraugus } \\
\text { Steuben } \\
\text { Allegany } \\
\text { Cattaraugus } \\
\text { Allegany } \\
\text { Steuben }\end{array}$ & $\begin{array}{l}- \\
0.02 \\
.26 \\
= \\
.30 \\
.06 \\
= \\
= \\
=\end{array}$ & $\begin{array}{r}0.16 \\
.80 \\
3.38 \\
.72 \\
.40 \\
.24 \\
.10 \\
.97 \\
. \\
1.19 \\
.10 \\
.42\end{array}$ & $\begin{array}{r}5.58 \\
.11 \\
2.69 \\
3.39 \\
1.98 \\
.87 \\
.56 \\
.33 \\
6.70 \\
.08 \\
1.93 \\
3.85 \\
1.55\end{array}$ & $\begin{array}{r}0.24 \\
- \\
.28 \\
1.69 \\
1.14 \\
.75 \\
1.00 \\
.10 \\
. \\
.28 \\
.09 \\
.69 \\
.38\end{array}$ & $\begin{array}{l}0.66 \\
- \\
.51 \\
. \\
.47 \\
.07 \\
.11 \\
.28 \\
.95 \\
.02 \\
.24 \\
. \\
.11\end{array}$ & $\begin{array}{l}5.82 \\
.91 \\
6.07 \\
5.08 \\
3.12 \\
1.62 \\
1.56 \\
1.30 \\
6.70 \\
1.28 \\
2.02 \\
4.54 \\
1.97\end{array}$ \\
\hline \multicolumn{8}{|l|}{ Great Lakes } \\
\hline $\begin{array}{l}\text { Brockport } \\
\text { Buffalo } \\
\text { Fredonia } \\
\text { Herrings } \\
\text { Jamestown } \\
\text { Lewiston } \\
\text { Linden (c) } \\
\text { Lockport } \\
\text { Oswego } \\
\text { Rochester } \\
\text { South Wales } \\
\text { Stafford } \\
\text { Watertown }\end{array}$ & $\begin{array}{l}\text { Monroe } \\
\text { Erie } \\
\text { Chautauqua } \\
\text { Jefferson } \\
\text { Chautauqua } \\
\text { N1agara } \\
\text { Genesee } \\
\text { N1agara } \\
\text { Oswego } \\
\text { Monroe } \\
\text { Erie } \\
\text { Genesee } \\
\text { Jefferson }\end{array}$ & $\begin{array}{l}\bar{T} \\
. \\
.40 \\
\overline{-} \\
- \\
.31 \\
.13 \\
- \\
.47\end{array}$ & $\begin{array}{c}.17 \\
- \\
- \\
1.70 \\
- \\
.20 \\
1.25 \\
.38 \\
.55 \\
2.13 \\
.35 \\
.73 \\
.84\end{array}$ & $\begin{array}{l}.04 \\
.28 \\
.09 \\
.12 \\
.33 \\
.02 \\
1.08 \\
.12 \\
.63 \\
.08 \\
.01 \\
.01 \\
.09\end{array}$ & $\begin{array}{l}- \\
- \\
.35 \\
T \\
T \\
.02 \\
.58 \\
.08 \\
.08 \\
.15\end{array}$ & $\begin{array}{l}\overline{-} \\
= \\
.01 \\
= \\
= \\
= \\
= \\
- \\
.24\end{array}$ & $\begin{array}{r}.21 \\
.28 \\
.09 \\
2.10 \\
.33 \\
.22 \\
2.33 \\
.50 \\
1.21 \\
2.34 \\
.35 \\
1.64 \\
1.31\end{array}$ \\
\hline \multicolumn{8}{|l|}{ Central Lakes } \\
\hline $\begin{array}{l}\text { Aubum } \\
\text { Avon } \\
\text { Baldwinsville (c) } \\
\text { Brewerton (c) } \\
\text { Bristol Springs (d) } \\
\text { Burdett (d) } \\
\text { Canastota (d) } \\
\text { Cayuga (c) } \\
\text { Cleveland (c) } \\
\text { Clyde (c) } \\
\text { Dansville } \\
\text { Fulton (c) } \\
\text { Geneva } \\
\text { Hammondsport (d) } \\
\text { Hemlock } \\
\text { Ithaca } \\
\text { Letchworth Park } \\
\text { Locke (d) } \\
\text { Macedon (c) } \\
\text { Mays Point (c) } \\
\text { Newark (c) } \\
\text { New London (c) } \\
\text { Ovid (d) } \\
\text { Penn Yan } \\
\text { Shortsville } \\
\text { Skaneateles } \\
\text { Syracuse } \\
\text { Waterloo (c) } \\
\text { W1lilamstom (d) }\end{array}$ & $\begin{array}{l}\text { Cayuga } \\
\text { Livings ton } \\
\text { Onondaga } \\
\text { Onondaga } \\
\text { Ontario } \\
\text { Schujler } \\
\text { Madison } \\
\text { Cayuga } \\
\text { Oswego } \\
\text { Wayne } \\
\text { Livingston } \\
\text { Oswego } \\
\text { Ontario } \\
\text { Steuben } \\
\text { Livingston } \\
\text { Tompkins } \\
\text { Wyoming } \\
\text { Cayuga } \\
\text { Wayne } \\
\text { Seneca } \\
\text { Wayne } \\
\text { Oneida } \\
\text { Seneca } \\
\text { Yates } \\
\text { Ontario } \\
\text { Onondaga } \\
\text { Onondaga } \\
\text { Seneca } \\
\text { Oswego }\end{array}$ & 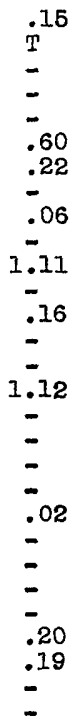 & $\begin{array}{r}.44 \\
.25 \\
.12 \\
.21 \\
1.29 \\
2.00 \\
1.79 \\
.08 \\
2.30 \\
.14 \\
1.00 \\
.09 \\
.82 \\
1.90 \\
.75 \\
3.62 \\
.25 \\
1.23 \\
2.30 \\
.16 \\
.98 \\
.60 \\
2.23 \\
1.25 \\
2.00 \\
.84 \\
2.05 \\
.25 \\
.27\end{array}$ & $\begin{array}{r}.90 \\
.05 \\
2.90 \\
6.82 \\
3.70 \\
8.50 \\
1.14 \\
.98 \\
.48 \\
1.18 \\
3.69 \\
2.80 \\
1.41 \\
6.10 \\
.38 \\
4.60 \\
.51 \\
3.47 \\
.70 \\
.87 \\
1.09 \\
3.05 \\
7.61 \\
4.08 \\
.64 \\
.63 \\
1.25 \\
1.54 \\
1.73\end{array}$ & $\begin{array}{r}.29 \\
.15 \\
.35 \\
.46 \\
1.20 \\
.60 \\
.42 \\
1.23 \\
.12 \\
.74 \\
.68 \\
.15 \\
.07 \\
.47 \\
.07 \\
.26 \\
1.30 \\
.78 \\
.7 \\
.70 \\
.20 \\
1.42 \\
.77 \\
- \\
2.18 \\
1.36 \\
.13 \\
.85 \\
.29\end{array}$ & $\begin{array}{l}.01 \\
1.87 \\
.07 \\
.06 \\
.04 \\
.05 \\
.02 \\
.22 \\
.76 \\
.12 \\
.22 \\
.28 \\
.02 \\
.04 \\
.15 \\
.60 \\
.04 \\
.26 \\
.01 \\
.20 \\
.23 \\
.10 \\
.03 \\
.01 \\
T \\
.04 \\
.09\end{array}$ & $\begin{array}{r}1.34 \\
2.02 \\
3.25 \\
7.28 \\
4.99 \\
10.50 \\
2.93 \\
2.21 \\
2.78 \\
1.92 \\
4.69 \\
2.95 \\
2.23 \\
8.00 \\
1.13 \\
8.22 \\
1.81 \\
4.70 \\
3.00 \\
1.57 \\
2.07 \\
4.47 \\
9.84 \\
5.33 \\
2.82 \\
1.99 \\
3.30 \\
2.39 \\
2.02\end{array}$ \\
\hline
\end{tabular}

a Record furnished by $U$. S. Soll Conservation Service.

$b$ Record furnished by U. S. Geological Survey.

c Record furnished by New York State Department of Publ1c Works.

d Record furnished by Oswego River Watershed Co. 
Daily and maximum 2-day rainfall, in inches--Continued

\begin{tabular}{|c|c|c|c|c|c|c|c|}
\hline \multirow{2}{*}{ Station } & \multirow{2}{*}{ County } & \multicolumn{5}{|c|}{ July } & \multirow{2}{*}{$\begin{array}{l}\text { aximun } \\
\text { D-day }\end{array}$} \\
\hline & & 6 & 7 & 8 & 9 & 10 & \\
\hline 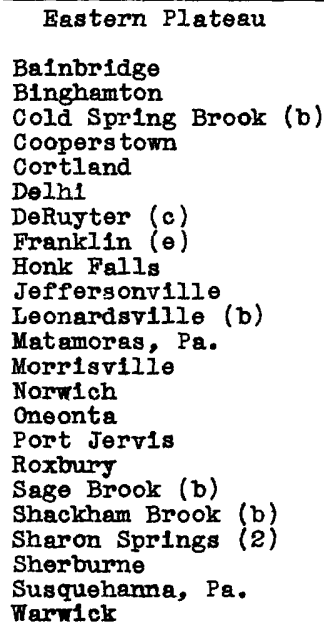 & $\begin{array}{l}\text { Chenango } \\
\text { Broome } \\
\text { Delaware } \\
\text { Otsego } \\
\text { Cortland } \\
\text { Delaware } \\
\text { Madison } \\
\text { Delawrer } \\
\text { Ulster } \\
\text { Sullivan } \\
\text { Madison } \\
\text { P1ke } \\
\text { Madison } \\
\text { Chenango } \\
\text { Otsego } \\
\text { Orange } \\
\text { Delaware } \\
\text { Chenango } \\
\text { Cortland } \\
\text { Schohario } \\
\text { Chenango } \\
\text { Susquehgnn }\end{array}$ & $\begin{array}{l}0.27 \\
.07 \\
- \\
T \\
\bar{T} \\
= \\
= \\
.02 \\
.11 \\
.25 \\
.09 \\
.31 \\
1.39 \\
.22 \\
- \\
=\end{array}$ & $\begin{array}{r}- \\
0.07 \\
1.48 \\
.84 \\
1.70 \\
- \\
.98 \\
.69 \\
5.10 \\
.04 \\
.69 \\
- \\
3.04 \\
2.97 \\
1.47 \\
.40 \\
.87 \\
2.12 \\
2.25 \\
2.50 \\
.32 \\
- \\
.11\end{array}$ & $\begin{array}{l}4.10 \\
1.02 \\
1.70 \\
4.49 \\
7.67 \\
8.52 \\
2.25 \\
6.50 \\
1.00 \\
.53 \\
2.05 \\
.08 \\
2.50 \\
6.10 \\
5.24 \\
2.29 \\
1.85 \\
4.55 \\
2.10 \\
1.65 \\
3.56 \\
.58 \\
-\end{array}$ & $\begin{array}{r}1.25 \\
.31 \\
.57 \\
.13 \\
1.78 \\
.16 \\
.86 \\
1.27 \\
.31 \\
.86 \\
1.31 \\
2.86 \\
.17 \\
.49 \\
.23 \\
.75 \\
.34 \\
.22 \\
.46 \\
.09 \\
1.02 \\
2.22 \\
.19\end{array}$ & $\begin{array}{l}0.21 \\
.22 \\
.02 \\
1.06 \\
.39 \\
.75 \\
- \\
.37 \\
.05 \\
.42 \\
.51 \\
.28 \\
.43 \\
.11 \\
.18 \\
.06 \\
.53 \\
.09 \\
.08 \\
.74 \\
.19 \\
.40 \\
.11\end{array}$ & $\begin{array}{l}5.35 \\
1.38 \\
3.59 \\
5.33 \\
9.45 \\
8.68 \\
3.23 \\
7.77 \\
6.10 \\
1.39 \\
3.36 \\
3.14 \\
5.54 \\
9.07 \\
6.71 \\
3.04 \\
2.72 \\
6.80 \\
4.94 \\
4.15 \\
4.58 \\
2.80 \\
.30\end{array}$ \\
\hline \multicolumn{8}{|l|}{ Mohamix Valley } \\
\hline 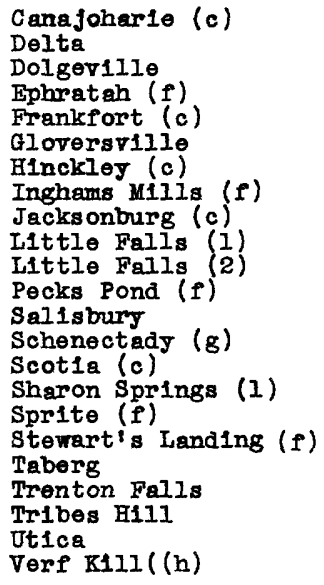 & $\begin{array}{l}\text { Montgomery } \\
\text { One1da } \\
\text { Herikimer } \\
\text { Fulton } \\
\text { Herkimer } \\
\text { Fulton } \\
\text { One1da } \\
\text { Herk1mer } \\
\text { Herk1mer } \\
\text { Herkimer } \\
\text { Herk1mer } \\
\text { Fulton } \\
\text { Herk1mer } \\
\text { Schenectady } \\
\text { Schenectady } \\
\text { Schoharie } \\
\text { Fulton } \\
\text { Fulton } \\
\text { One1da } \\
\text { One1da } \\
\text { Montgomery } \\
\text { One1da } \\
\text { Schenectady }\end{array}$ & $\begin{array}{l}= \\
= \\
= \\
= \\
= \\
= \\
= \\
= \\
= \\
.12 \\
. \\
.02 \\
.46 \\
.38\end{array}$ & $\begin{array}{r}.59 \\
.25 \\
.80 \\
.37 \\
.62 \\
1.90 \\
.74 \\
.31 \\
.21 \\
.82 \\
.21 \\
. .05 \\
2.05 \\
.49 \\
2.50 \\
3.21 \\
.53 \\
.79 \\
.01 \\
1.85 \\
.96 \\
.06 \\
1.80\end{array}$ & $\begin{array}{r}2.42 \\
3.15 \\
4.87 \\
2.76 \\
2.65 \\
2.10 \\
1.60 \\
4.23 \\
2.84 \\
3.35 \\
4.02 \\
5.99 \\
3.20 \\
2.01 \\
T \\
.96 \\
4.10 \\
5.96 \\
2.50 \\
1.45 \\
3.63\end{array}$ & $\begin{array}{r}.40 \\
2.10 \\
1.62 \\
.11 \\
.82 \\
.16 \\
.96 \\
1.58 \\
.90 \\
.20 \\
1.90 \\
.18 \\
.16 \\
.56 \\
.59 \\
.07 \\
1.37 \\
3.03 \\
.30 \\
.22 \\
.30 \\
.15 \\
.16\end{array}$ & $\begin{array}{l}- \\
.21 \\
- \\
.19 \\
.29 \\
.31 \\
.59 \\
.26 \\
.29 \\
.52 \\
.33 \\
.14 \\
.34 \\
.34 \\
.36 \\
.67 \\
.13 \\
.17 \\
.18 \\
.12 \\
.20 \\
.04 \\
.\end{array}$ & $\begin{array}{l}5 . \\
6 . \\
3 . \\
3 . \\
4 . \\
2 . \\
5 . \\
3 . \\
4 . \\
5 \\
6 . \\
5 . \\
2 . \\
2 . \\
4 . \\
5 . \\
8 . \\
2 . \\
3 . \\
4 . \\
3 . \\
2 .\end{array}$ \\
\hline \multicolumn{8}{|l|}{ Northern Plateau } \\
\hline $\begin{array}{l}\text { Beaver Falls } \\
\text { Bennettis Bridge (1) } \\
\text { B1g Moose } \\
\text { Bomaparte } \\
\text { Boonville } \\
\text { Colton } \\
\text { Copenhagen } \\
\text { Eagle Falls }\end{array}$ & $\begin{array}{l}\text { Lerils } \\
\text { Oswego } \\
\text { Herikfimer } \\
\text { Lerts } \\
\text { Oneida } \\
\text { St. Lawrence } \\
\text { Leits } \\
\text { Lew1s }\end{array}$ & $\begin{array}{l}.41 \\
.05 \\
\frac{T}{1}\end{array}$ & $\begin{array}{r}1.40 \\
.80 \\
.64 \\
.25 \\
.01 \\
4.02 \\
2.13\end{array}$ & $\begin{array}{r}1.00 \\
.61 \\
.76 \\
2.05 \\
1.85 \\
1.90 \\
717\end{array}$ & $\begin{array}{l}.16 \\
.12 \\
.36 \\
.51 \\
.55 \\
.65 \\
.07 \\
.20\end{array}$ & $\begin{array}{l}.03 \\
1.61 \\
- \\
.30 \\
.37 \\
. \\
.49\end{array}$ & $\begin{array}{l}2.01 \\
1.56 \\
2.69 \\
2.40 \\
2.55 \\
4.19 \\
3.32\end{array}$ \\
\hline
\end{tabular}

b Record furnished by U. S. Geological Survey

c Record furnished by New York State Department of Public Works.

$\theta$ Record furnished by Arthur Bennett

$f$ Record furnished by New York IIght and Power Co.

$g$ Record furnished by Sanitary Engineer, City of Schenectady, N. Y.

$h$ Record furnished by Malcolm I. Fisher, Scotia, N. Y.

1 Record furnished by Niagara-Hudson Corporation. 
Da1ly and maximum 2-day rainfall, in inches--Continued

\begin{tabular}{|c|c|c|c|c|c|c|c|}
\hline \multirow{2}{*}{ Station } & \multirow{2}{*}{ County } & \multicolumn{5}{|c|}{ Julg } & \multirow{2}{*}{${ }_{2-d a y}^{\text {Maximum }}$} \\
\hline & & 6 & 7 & 8 & 9 & 10 & \\
\hline Northern Plateau-Cont. & & & & & & & \\
\hline $\begin{array}{l}\text { Gabriels } \\
\text { Hoffmelster } \\
\text { Hope } \\
\text { Indian Lake } \\
\text { Lake Placid Club } \\
\text { Lorvilie } \\
\text { Lyons Falls } \\
\text { MeKeever } \\
\text { North Iake } \\
\text { Raquette Lake } \\
\text { Sabattis } \\
\text { South Edrards } \\
\text { Sperryville } \\
\text { St1liwater Reservolr } \\
\text { Tupper Lake } \\
\text { Wanakena }\end{array}$ & $\begin{array}{l}\text { Franklin } \\
\text { Hamilton } \\
\text { Hamilton } \\
\text { Hamilton } \\
\text { Essex } \\
\text { Leris } \\
\text { Levis } \\
\text { Herkimer } \\
\text { Herkimer } \\
\text { Hamilton } \\
\text { Hamilton } \\
\text { St. Lavrence } \\
\text { Lewis } \\
\text { Herkimer } \\
\text { Franklin } \\
\text { St. Inwence }\end{array}$ & $\begin{array}{l}\overline{-} \\
= \\
1.00 \\
.10 \\
.50 \\
= \\
.10 \\
.20 \\
1.20 \\
= \\
.61 \\
.48\end{array}$ & $\begin{array}{r}0.09 \\
2.32 \\
.58 \\
.54 \\
.52 \\
1.82 \\
1.19 \\
.58 \\
.96 \\
.50 \\
.36 \\
2.79 \\
.77 \\
1.29 \\
.80 \\
1.21\end{array}$ & $\begin{array}{r}0.14 \\
1.00 \\
2.30 \\
1.03 \\
.70 \\
.06 \\
1.81 \\
1.46 \\
1.37 \\
.70 \\
.60 \\
.01 \\
1.82 \\
.90 \\
.13 \\
.13\end{array}$ & $\begin{array}{l}0.27 \\
1.14 \\
1.09 \\
1.30 \\
.11 \\
.26 \\
.28 \\
.94 \\
.13 \\
.12 \\
.33 \\
.50 \\
.10 \\
.23 \\
.33 \\
.12\end{array}$ & $\begin{array}{c}0.11 \\
.24 \\
.18 \\
.14 \\
- \\
.06 \\
.45 \\
.45 \\
.33 \\
.18 \\
- \\
- \\
1.16 \\
.21 \\
.03 \\
.05\end{array}$ & $\begin{array}{l}0.41 \\
3.32 \\
3.39 \\
2.33 \\
1.22 \\
2.32 \\
3.00 \\
2.40 \\
2.33 \\
1.20 \\
.96 \\
3.99 \\
2.59 \\
2.19 \\
1.41 \\
1.69\end{array}$ \\
\hline \multicolumn{8}{|l|}{ Hudson Valloy } \\
\hline 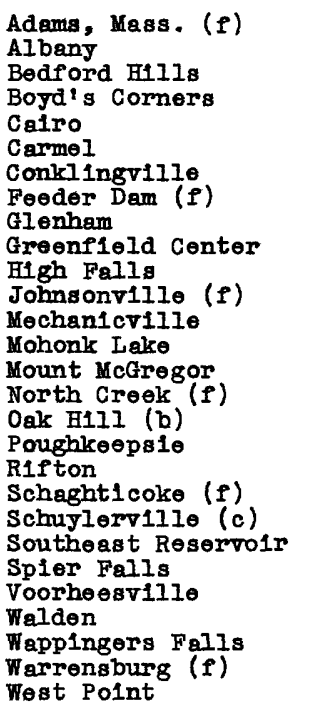 & $\begin{array}{l}\text { Berkahire } \\
\text { Albany } \\
\text { Westchester } \\
\text { Putnam } \\
\text { Greene } \\
\text { Putnam } \\
\text { Saratoga } \\
\text { Saratoge } \\
\text { Dutchess } \\
\text { Saratoga } \\
\text { Olster } \\
\text { Rensselaer } \\
\text { Saratoga } \\
\text { Ulster } \\
\text { Saratoga } \\
\text { Warren } \\
\text { Greene } \\
\text { Dutchess } \\
\text { Ulster } \\
\text { Rennsselaer } \\
\text { Saratoga } \\
\text { Putnam } \\
\text { Saratoga } \\
\text { Albany } \\
\text { Orange } \\
\text { Dutchess } \\
\text { Warren } \\
\text { Orange }\end{array}$ & 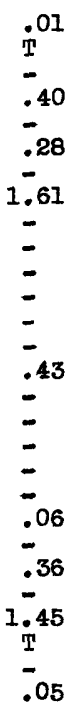 & $\begin{array}{r}1.03 \\
2.08 \\
. \\
.42 \\
2.48 \\
.18 \\
4.73 \\
1.37 \\
. \\
2.80 \\
1.95 \\
1.37 \\
.95 \\
.30 \\
4.70 \\
.98 \\
2.35 \\
.33 \\
.40 \\
1.50 \\
4.53 \\
.16 \\
5.10 \\
. \\
.06 \\
.01 \\
3.40 \\
T\end{array}$ & $\begin{array}{r}2.59 \\
.59 \\
.38 \\
.17 \\
3.52 \\
.18 \\
.70 \\
5.00 \\
.10 \\
2.00 \\
.20 \\
1.74 \\
1.89 \\
.58 \\
2.87 \\
1.00 \\
.35 \\
.25 \\
.34 \\
1.67 \\
.24 \\
.35 \\
2.95 \\
2.39 \\
.25 \\
.09 \\
3.53 \\
.24\end{array}$ & $\begin{array}{r}.05 \\
.06 \\
.32 \\
.48 \\
.28 \\
.28 \\
.15 \\
1.57 \\
.22 \\
.05 \\
.10 \\
. \\
.27 \\
.43 \\
.85 \\
1.33 \\
.95 \\
.23 \\
.10 \\
. \\
.08 \\
.25 \\
.24 \\
.55 \\
.21 \\
.36 \\
2.02 \\
.30\end{array}$ & $\begin{array}{l}.06 \\
.46 \\
.47 \\
.06 \\
.05 \\
.01 \\
. \\
.19 \\
.30 \\
.30 \\
.06 \\
.09 \\
.01 \\
.42 \\
.17 \\
.12 \\
.07 \\
.10 \\
.1 \\
.04 \\
.34 \\
.32 \\
5 \\
T \\
.15 \\
.28\end{array}$ & $\begin{array}{r}3.62 \\
2.67 \\
.79 \\
.82 \\
6.00 \\
.46 \\
5.43 \\
6.57 \\
.52 \\
4.80 \\
2.15 \\
3.11 \\
2.84 \\
1.01 \\
7.57 \\
2.33 \\
2.70 \\
.58\end{array}$ \\
\hline \multicolumn{8}{|l|}{ Atlant1c Coast } \\
\hline $\begin{array}{l}\text { Bridgehampton } \\
\text { Cutchogue } \\
\text { Flushing } \\
\text { Hicksvilie } \\
\text { Mount Vernon } \\
\text { New York City } \\
\text { Scarsdale } \\
\text { Setauket }\end{array}$ & $\begin{array}{l}\text { Suffolk } \\
\text { Suffolk } \\
\text { Queens } \\
\text { Nassau } \\
\text { Westchester } \\
\text { New York } \\
\text { Westchester } \\
\text { Suffolk }\end{array}$ & $\begin{array}{l}= \\
= \\
= \\
=\end{array}$ & $\vec{T}$ & $\begin{array}{l}.12 \\
.03 \\
.05 \\
.02\end{array}$ & $\begin{array}{r}.88 \\
1.25 \\
.36 \\
.18 \\
.48\end{array}$ & $\begin{array}{l}\mathrm{T} \\
- \\
.12 \\
.19 \\
.43 \\
.30 \\
.37 \\
-\end{array}$ & 9 \\
\hline
\end{tabular}

b Record furnished by U. S. Geological Surrey.

c Record furnished by New York State Department of Publ1c Works.

$f$ Record fumlshed by New York Light and Power Co. 
Daily and maximum 2-day rainfall, in inches--Continued

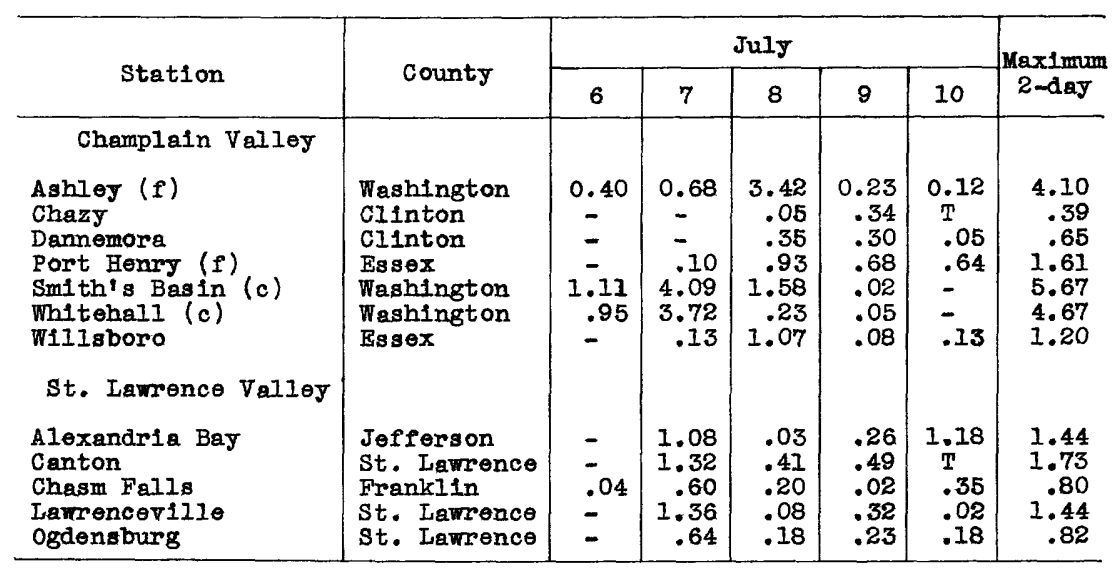

c Record furnished by New York State Department of Public Works.

$f$ Record furnished by New York Ilght and Power Co.

The table of "Hourly rainfall, in inches" shows the rainfall as recorded by automatic rain gages at nine stations in or near the main storm area. Unfortunately, none of these gages were within the area of the most intense precipitation, and therefore they did not furnish information on what actually took place in that area. That at $10 a \mathrm{st} 12$ to 14 inches of rain fell in 12 to 16 hours is indicated by the amounts of rainfali measured in open receptacles after the storm. 
Eourly rainfall, in inches

\begin{tabular}{|c|c|c|c|c|c|c|c|c|c|c|c|c|c|c|c|c|c|c|c|c|c|c|c|c|c|c|}
\hline \multirow{2}{*}{ Recording gage station } & \multirow{2}{*}{ Bounty } & \multirow{2}{*}{ Jaly } & \multicolumn{12}{|c|}{ A.w. } & \multicolumn{12}{|c|}{ P.1. } \\
\hline & & & 1 & 2 & 3 & 4 & 5 & 6 & 7 & 8 & 9 & 10 & 11 & 12 & 1 & 2 & 3 & 4 & 5 & 6 & 7 & 8 & 9 & 10 & 11 & 12 \\
\hline $\begin{array}{l}\text { Arnot, N. Y. Y. } \\
\text { V. S. Soli conservam } \\
\text { tion Service }\end{array}$ & Schurgler & $\begin{array}{l}6 \\
7 \\
8 \\
9\end{array}$ & $\left|\begin{array}{r}0.01 \\
.10 \\
.01\end{array}\right|$ & \begin{tabular}{c|}
- \\
- \\
0.21 \\
.01 \\
\end{tabular} & $\begin{array}{c}- \\
0.03 \\
.03\end{array}$ & $\begin{array}{r}0.03 \\
.06\end{array}$ & 0.03 & 0.25 & $\mid \begin{array}{c}- \\
-\overline{11} \\
0.02\end{array}$ & $\begin{array}{c}\overline{-} \\
0.10\end{array}$ & $\begin{array}{l}\bar{z} \\
\bar{z}\end{array}$ & \begin{tabular}{c|} 
\\
$\bar{z}$ \\
0.02
\end{tabular} & \begin{tabular}{|c|} 
\\
0.25 \\
.16
\end{tabular} & $\begin{array}{c}- \\
\bar{z} \\
-15 \\
-\end{array}$ & $\begin{array}{c}- \\
\bar{z} \\
0.01\end{array}$ & $=$ & $\begin{array}{c}= \\
0.02\end{array}$ & \begin{tabular}{|c|}
0.09 \\
.01 \\
.02 \\
\end{tabular} & \begin{tabular}{|c|}
0.01 \\
.61 \\
.01 \\
-
\end{tabular} & $\begin{array}{c}- \\
0.05 \\
.47 \\
.01\end{array}$ & $\begin{array}{c}-\overline{11} \\
.01\end{array}$ & $\begin{array}{r}- \\
0.17 \\
.03 \\
.03\end{array}$ & $\begin{array}{c}\bar{z} \\
\overline{0} \\
0.05\end{array}$ & $\begin{array}{c}- \\
0.19 \\
-\end{array}$ & $\begin{array}{c}0.22 \\
.18 \\
-\end{array}$ & $\begin{array}{c}0.06 \\
.02 \\
.02 \\
-\end{array}$ \\
\hline $\begin{array}{l}\text { Binghamton, N. Y. } \\
\text { J. S. Veather Bureau }\end{array}$ & Broome & $\begin{array}{l}6 \\
7 \\
8 \\
9\end{array}$ & $\begin{array}{l}- \\
.05 \\
.03\end{array}$ & $\begin{array}{l}\bar{T} \\
.01\end{array}$ & $\bar{E}$ & $\begin{array}{l}- \\
\overline{.01} \\
\mathrm{~T}\end{array}$ & $\begin{array}{l}\bar{T} \\
\bar{T}\end{array}$ & $\begin{array}{l}- \\
- \\
T \\
.01\end{array}$ & $\begin{array}{c}- \\
-0.6 \\
.01\end{array}$ & $\begin{array}{l}- \\
-.04 \\
.02\end{array}$ & $\mid \begin{array}{c}- \\
0 . \overline{18} \\
.04\end{array}$ & $\begin{array}{l}- \\
.02 \\
.03\end{array}$ & $\bar{E}$ & $\begin{array}{l}- \\
.24 \\
.02\end{array}$ & $\bar{z}$ & $\frac{-}{T}$ & $\begin{array}{l}\bar{T} \\
.01\end{array}$ & $\begin{array}{l}\bar{T} \\
T \\
.02\end{array}$ & $\mid \begin{array}{l}- \\
\mathbf{T} \\
\mathbf{T} \\
.07\end{array}$ & $\begin{array}{l}T \\
T \\
.02\end{array}$ & $\begin{array}{l}- \\
.01 \\
.07 \\
.02\end{array}$ & $\begin{array}{l}\overline{01} \\
.13 \\
T\end{array}$ & $\begin{array}{l}- \\
.09 \\
-\end{array}$ & $\begin{array}{l}- \\
.11\end{array}$ & $\begin{array}{l}T \\
.12 \\
-\end{array}$ & $\begin{array}{l}.27 \\
.05 \\
-\end{array}$ \\
\hline $\begin{array}{l}\text { Cold spring Broots } \\
\text { Ohina, II. Y. Y. } \\
\text { U. s. Geol. Survey }\end{array}$ & Delaware & $\begin{array}{l}6 \\
7 \\
8 \\
9\end{array}$ & $\begin{array}{l}- \\
\overline{.17}\end{array}$ & $\begin{array}{l}\overline{-} \\
.01\end{array}$ & $\begin{array}{l}\overline{-} \\
.03\end{array}$ & $\begin{array}{l}- \\
-39 \\
-\end{array}$ & $\begin{array}{l}- \\
\bar{z} \\
.02\end{array}$ & $\begin{array}{l}- \\
-03\end{array}$ & $\begin{array}{l}- \\
.01 \\
.02\end{array}$ & $\begin{array}{l}- \\
.10 \\
.04\end{array}$ & $\begin{array}{l}- \\
.38 \\
.05\end{array}$ & $\begin{array}{l}- \\
.02 \\
.02\end{array}$ & $\begin{array}{l}.02 \\
.06 \\
.01\end{array}$ & $\begin{array}{l}.02 \\
.12 \\
.01\end{array}$ & $\begin{array}{l}- \\
-10 \\
-\end{array}$ & $\left|\begin{array}{c}0.01 \\
.28 \\
-01 \\
.01\end{array}\right|$ & $\bar{z}$ & $\begin{array}{l}= \\
\overline{-05}\end{array}$ & $\begin{array}{l}- \\
\overline{-} \\
.02\end{array}$ & $\begin{array}{l}z \\
\overline{-04}\end{array}$ & $\begin{array}{l}\overline{-} \\
\overline{-04}\end{array}$ & $\begin{array}{l}.02 \\
.82 \\
.01 \\
-\end{array}$ & $\begin{array}{l}-\overline{38} \\
- \\
-\end{array}$ & $\begin{array}{l}- \\
.04 \\
-\end{array}$ & $\begin{array}{l}- \\
-30 \\
-\end{array}$ & $\overline{-}$ \\
\hline $\begin{array}{l}\text { Ithaoa, N. Y. } \\
\text { U. S. Weather }\end{array}$ & Tompkans & $\begin{array}{l}6 \\
7 \\
8 \\
9\end{array}$ & $\begin{array}{c}- \\
T \\
1.20 \\
.01\end{array}$ & $\begin{array}{c}- \\
1 . \overline{1} 2\end{array}$ & $\begin{array}{l}- \\
.45 \\
.01\end{array}$ & $\bar{z}$ & $\begin{array}{l}- \\
\bar{T}^{32}\end{array}$ & $\begin{array}{l}- \\
.04 \\
.03\end{array}$ & $\begin{array}{l}- \\
-01 \\
.01\end{array}$ & $\begin{array}{l}E \\
\bar{n}\end{array}$ & $\overline{-}$ & $\begin{array}{l}- \\
.15 \\
m\end{array}$ & $\begin{array}{l}- \\
.24 \\
.20\end{array}$ & $\begin{array}{l}- \\
.14\end{array}$ & $\begin{array}{l}- \\
\tilde{0} \\
\vdots\end{array}$ & $\begin{array}{l}T \\
T \\
.17 \\
: \approx 2\end{array}$ & $\begin{array}{l}.08 \\
\mathbf{T} \\
T \\
z\end{array}$ & $\begin{array}{l}.01 \\
. \overline{16} \\
\overline{2}\end{array}$ & $\begin{array}{l}-54 \\
.54 \\
. \hat{v i s}\end{array}$ & \begin{tabular}{l|}
- \\
.91 \\
.12 \\
. $\bar{u} 2$
\end{tabular} & $\begin{array}{l}\bar{T} \\
: 122 \\
. \overline{0} \overline{0}\end{array}$ & $\begin{array}{l}- \\
.23 \\
.07 \\
x\end{array}$ & $\begin{array}{l}- \\
.50 \\
.01\end{array}$ & $\begin{array}{l}.55 \\
.63 \\
- \\
T\end{array}$ & $\begin{array}{l}.41 \\
.17 \\
7\end{array}$ & $\begin{array}{l}.07 \\
.64 \\
.01\end{array}$ \\
\hline $\begin{array}{l}\text { Lost Nat1on Brook } \\
\text { Centerville, N. Y. } \\
\text { U. S. Geol. Survey }\end{array}$ & Allegany & $\begin{array}{l}6 \\
7 \\
8 \\
9\end{array}$ & $\begin{array}{l}\bar{z} \\
\overline{-}\end{array}$ & $\begin{array}{l}- \\
\overline{-01} \\
-\end{array}$ & $\begin{array}{l}z \\
z\end{array}$ & $\overline{-}$ & $\begin{array}{l}\bar{z} \\
\bar{z}\end{array}$ & - & $\bar{z}$ & $\begin{array}{l}\bar{z} \\
\overline{-}\end{array}$ & $\begin{array}{l}\bar{z} \\
\bar{z}\end{array}$ & $\begin{array}{l}- \\
- \\
.01 \\
.01\end{array}$ & $\begin{array}{l}- \\
.45 \\
.01 \\
-\end{array}$ & $\begin{array}{l}.70 \\
-\end{array}$ & $\begin{array}{l}-02 \\
- \\
-\end{array}$ & $\begin{array}{l}- \\
-02 \\
-\end{array}$ & $\begin{array}{l}\bar{z} \\
\overline{-}\end{array}$ & $\begin{array}{l}\bar{z} \\
\bar{z}\end{array}$ & $\begin{array}{l}- \\
.05 \\
-\end{array}$ & $\begin{array}{l}E \\
- \\
.13\end{array}$ & $\begin{array}{l}\bar{z} \\
\overline{-}\end{array}$ & $\begin{array}{l}\bar{z} \\
\bar{z}\end{array}$ & $\begin{array}{l}\bar{z} \\
\overline{-}\end{array}$ & $\begin{array}{l}\overline{-} \\
\overline{.14}\end{array}$ & $\bar{z}$ & $\begin{array}{l}\bar{z} \\
\overline{-}\end{array}$ \\
\hline $\begin{array}{l}\text { Roohester, } \\
\text { U. S. Weat }\end{array}$ & Monsoe & $\begin{array}{l}6 \\
7 \\
8 \\
9\end{array}$ & $\begin{array}{l}- \\
-01 \\
-\end{array}$ & $\begin{array}{l}\bar{p} \\
? \\
-\end{array}$ & $\begin{array}{l}-\bar{r} \\
.08 \\
-\end{array}$ & $\begin{array}{l}\overline{-} \\
\dot{x}^{01} \\
-\end{array}$ & $\begin{array}{l}\bar{z} \\
\overline{-}\end{array}$ & $=$ & $\begin{array}{l}\overline{-} \\
\overline{-}\end{array}$ & $\begin{array}{l}E \\
\bar{z}\end{array}$ & $\bar{z}$ & $\begin{array}{l}\bar{z} \\
\bar{y}\end{array}$ & $\begin{array}{c}\overline{-} \\
\overline{0} \\
0.07\end{array}$ & $\begin{array}{l}-.02 \\
.02 \\
.02\end{array}$ & $\begin{array}{c}- \\
2.09 \\
-\end{array}$ & $=$ & $\begin{array}{l}\bar{z} \\
\bar{z}\end{array}$ & $\bar{z}$ & $=$ & $\begin{array}{l}\bar{y} \\
\bar{y}\end{array}$ & $\begin{array}{l}\bar{z} \\
\overline{-}\end{array}$ & $\begin{array}{l}\bar{z} \\
\bar{y}\end{array}$ & $\begin{array}{l}\bar{z} \\
\overline{-}\end{array}$ & $\begin{array}{l}z \\
z\end{array}$ & $=$ & $\begin{array}{l}.13 \\
= \\
=\end{array}$ \\
\hline $\begin{array}{l}\text { Sage Brook } \\
\text { South Mrow Ber11n, N.Y. } \\
\text { O. \$. Gool. Surrey }\end{array}$ & Chenang & $\begin{array}{l}6 \\
7 \\
8 \\
9\end{array}$ & $\begin{array}{c}-.04 \\
. .01 \\
.08\end{array}$ & $\begin{array}{c}- \\
* .80 \\
-.\end{array}$ & $\frac{-}{.66}$ & $\begin{array}{l}- \\
.24\end{array}$ & $\bar{z} .26$ & $\begin{array}{l}- \\
\overline{-01}\end{array}$ & $\begin{array}{c}-01 \\
.01 \\
.04 \\
.01\end{array}$ & $\begin{array}{l}- \\
.01 \\
.02\end{array}$ & $\begin{array}{l}- \\
-26 \\
-\end{array}$ & $\begin{array}{l}- \\
.12 \\
.02\end{array}$ & $\begin{array}{l}- \\
.05 \\
-\end{array}$ & $\begin{array}{l}- \\
.05 \\
-\end{array}$ & $\begin{array}{l}z \\
.07 \\
-\end{array}$ & $\mid \begin{array}{c}- \\
* .24 \\
-\end{array}$ & $\overline{-.56}$ & $\overline{-}$ & $\begin{array}{l}\bar{Z} \\
.04\end{array}$ & $\begin{array}{l}- \\
.06 \\
-02\end{array}$ & $\begin{array}{c}- \\
. .17 \\
-03 \\
.03\end{array}$ & $\begin{array}{c}- \\
-.23 \\
-\end{array}$ & {$\left[\begin{array}{c}- \\
.23 \\
-\end{array}\right.$} & $\begin{array}{c}. .2 \\
.23 \\
.03 \\
.01\end{array}$ & $\begin{array}{c}.7 \\
.24 \\
.16\end{array}$ & $\begin{array}{r}. .31 \\
. .90 \\
.28 \\
-\end{array}$ \\
\hline $\begin{array}{l}\text { Shaockemam Brook } \\
\text { Truxton, N. Y. Y. } \\
\text { U. S. Goo1. Survey }\end{array}$ & Cortland & $\begin{array}{l}6 \\
7 \\
8 \\
9\end{array}$ & $\mid \begin{array}{c}. \\
.04 \\
.12 \\
.03\end{array}$ & $\begin{array}{r}. .03 \\
.12 \\
.03\end{array}$ & $\begin{array}{l}. .05 \\
.00 \\
.03\end{array}$ & $\begin{array}{r}. .03 \\
.08 \\
.02\end{array}$ & $\begin{array}{r}* .03 \\
.12 \\
.02 \\
\end{array}$ & $\begin{array}{r}. \\
.03 \\
.08 \\
.01\end{array}$ & $\begin{array}{r}.0 \\
.03 \\
.03 \\
.02\end{array}$ & \begin{tabular}{r|}
.01 \\
.02 \\
.02 \\
.02
\end{tabular} & $\begin{array}{l}.01 \\
- \\
.03\end{array}$ & $\begin{array}{l}\overline{-} \\
.03\end{array}$ & $\begin{array}{l}- \\
.05 \\
.04\end{array}$ & $\begin{array}{l}- \\
.24 \\
.04\end{array}$ & $\begin{array}{l}- \\
.04 \\
-\end{array}$ & $\begin{array}{l}.06 \\
.06 \\
-\end{array}$ & $\begin{array}{l}.01 \\
.04 \\
-\end{array}$ & $\begin{array}{l}.57 \\
.25 \\
.06 \\
.03\end{array}$ & $\begin{array}{r}- \\
. .16 \\
.40 \\
.02\end{array}$ & $\begin{array}{r}. . \\
.12 \\
.20 \\
.03\end{array}$ & $\begin{array}{r}* \\
.06 \\
.06 \\
.01\end{array}$ & $\begin{array}{l}. \\
. .28 \\
.10 \\
.01\end{array}$ & $\mid \begin{array}{c}-.28 \\
.06 \\
.01\end{array}$ & $\begin{array}{r}.06 \\
. .28 \\
.04 \\
.01\end{array}$ & $\left|\begin{array}{r}. .33 \\
. .28 \\
.06 \\
.01\end{array}\right|$ & $\begin{array}{r}. .34 \\
. .28 \\
.04 \\
.01\end{array}$ \\
\hline $\begin{array}{l}\text { Syracuse, N. Y. } \\
\text { J. S. Weather Bureau }\end{array}$ & Onondaga & $\begin{array}{l}6 \\
7 \\
8 \\
9\end{array}$ & $\begin{array}{l}- \\
.10 \\
.02\end{array}$ & $\begin{array}{l}- \\
.07 \\
.03\end{array}$ & $\bar{z}$ & $=$ & $\begin{array}{l}\overline{-} \\
.04\end{array}$ & $\overline{-}$ & $\overline{\bar{T}}$ & $\begin{array}{l}- \\
.02 \\
\end{array}$ & $\begin{array}{l}- \\
.01 \\
.01 \\
\bar{T}\end{array}$ & $\begin{array}{l}\bar{m} \\
\dot{p} \\
\dot{m}\end{array}$ & $=$ & $\begin{array}{l}\bar{z} \\
\overline{0} \\
-\end{array}$ & $\begin{array}{l}- \\
.03 \\
.10\end{array}$ & $\begin{array}{l}-.64 \\
T \\
T\end{array}$ & $\begin{array}{l}.25 \\
.03 \\
.03\end{array}$ & $\bar{i}^{-97}$ & $\begin{array}{l}.07 \\
.03 \\
.01\end{array}$ & $\begin{array}{l}- \\
.01 \\
.17 \\
.02\end{array}$ & $\begin{array}{l}- \\
.18 \\
.01\end{array}$ & $\begin{array}{l}- \\
+10 \\
.01\end{array}$ & $\begin{array}{l}- \\
.08 \\
.01\end{array}$ & $\begin{array}{l}T \\
? \\
.04 \\
.01\end{array}$ & $\begin{array}{l}.15 \\
.02 \\
.02\end{array}$ & $\begin{array}{l}.04 \\
.07 \\
i=7 \\
T\end{array}$ \\
\hline
\end{tabular}

* Estimatea, gage sticking. Total catch during estimated periods is correct. 
Fleld observations of results of erosion and washouts indicate that amounts of rainfall as great as those indicated in the following table, if not greater, may have occurred over a considerably larger area than is covered by these all too fer but very significant measurements.

Rainfall measured in open receptacles after the storm

(Furnished by U. S. Soll Conservetion Service, Bath, N. Y.)

\begin{tabular}{|c|c|c|c|c|}
\hline \multicolumn{3}{|c|}{ Location } & \multicolumn{2}{|c|}{ Rainfall, July 7-8, 1935} \\
\hline Latitude & Longitude & Resident's name & Inches & Time (hours) \\
\hline $\begin{array}{l}42031^{\prime} 00^{\prime \prime} \\
42018^{\prime} 30^{n} \\
42018^{\prime} 30^{\prime \prime} \\
42021^{\prime} 30^{\prime \prime} \\
42022^{\prime} 45^{\prime \prime}\end{array}$ & $\begin{array}{l}770^{\circ} 28^{\prime} 20^{\prime \prime} \\
77^{\circ} 30^{\prime} 40^{\prime \prime} \\
770^{\prime} 25^{\prime} 18^{\prime \prime} \\
77^{\circ} 29^{\prime} 20^{\prime \prime} \\
77^{\prime} 7^{\prime} 00^{\prime \prime}\end{array}$ & $\begin{array}{l}\text { J. Schultz } \\
\text { Mrs. McKinley } \\
\text { Herbert Ford } \\
\text { Mr. Wegner } \\
\text { New York State }\end{array}$ & $\begin{array}{c}7 \\
8.2 \\
12 \pm \\
8 \pm \\
9.5\end{array}$ & $\begin{array}{l}14 \\
12 \\
12 \\
36 \\
16\end{array}$ \\
\hline $\begin{array}{l}42021^{\prime} 45^{n} \\
42033^{\prime} 45^{n} \\
42031^{\prime} 30^{n} \\
42019^{\prime} 00^{\prime \prime} \\
42025^{\prime} 20^{\prime \prime}\end{array}$ & $\begin{array}{l}77018^{\prime} 45^{n} \\
77022^{\prime} 30^{n} \\
77021^{\prime} 25^{n} \\
77024^{\prime} 45^{n} \\
77034^{\prime} 00^{n}\end{array}$ & $\begin{array}{l}\text { H. W. Hobbs } \\
\text { J. F. Clelend } \\
\text { B. F. Edmonds } \\
\text { S. Dobbin } \\
\text { Haskinville Station, } \\
\text { W. G. Collins }\end{array}$ & $\begin{array}{l}6.1 \pm \\
8 \pm \\
7.0 \\
14 \pm \\
6.1\end{array}$ & $\begin{array}{l}141 \\
16 \\
16 \\
12 \\
16\end{array}$ \\
\hline $42030^{\prime} 15^{\pi}$ & $77029^{\prime} 30^{\prime \prime}$ & $\begin{array}{l}\text { Soll Conservation } \\
\text { Warehouse, Cohocton }\end{array}$ & 6.7 & 16 \\
\hline $\begin{array}{l}42038^{r} 00^{n} \\
42036^{\prime} 00^{\prime \prime} \\
42024^{\prime} 45^{n \prime} \\
42030^{\prime} 00^{\prime \prime} \\
42021^{\prime} 30^{\prime \prime} \\
42^{\circ} 18^{\prime} 15^{n \prime} \\
42017^{\prime} 30^{\prime \prime} \\
42017^{\prime} 34^{\prime \prime}\end{array}$ & 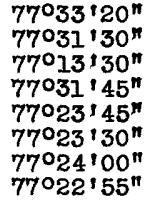 & $\begin{array}{l}\text { Mr. Bailey } \\
\text { Mr. GIbson } \\
\text { Hammondsport } \\
\text { B. Van Vlake } \\
\text { Mr. Chamberlain } \\
\text { R. Dobbins } \\
\text { T. W. Yiller } \\
\text { Ed Fenton }\end{array}$ & $\begin{array}{l}8 \\
6.5 \\
8.0 \\
9 \\
9.5 \\
12 \pm \\
11 \pm \\
14 \pm\end{array}$ & $\begin{array}{l}24 \\
24 \\
16 \\
12 \\
16 \\
16 \\
16 \\
16\end{array}$ \\
\hline
\end{tabular}

The measurements in the above table vere all made in the

vicinity of Bath. The following fer miscelleneous measurements of precipitation in open receptacles indicate that the stom was probably equally intense in other locelities.

Hector, N. Y. - "The total fall observed from 5 p.m. Saturday, July 6, to 7 a.m. Monday, July 8, was 14.23 inches. Ten inches of this amount fell during the 12-hour period ending at $7 \mathrm{a.m.} \mathrm{Mondey,} \mathrm{July} 8$. *** About a mile east of Hector and at an elevation of about 300 to 400 feet higher I found a reliable farmer who was astonished to find that more than 10 inches of rain was contained in his chicken-feed pail, which he was accustomed to set out on the ground in an open spot betreen the barn and house after feeding in the evening just before dark. This was on the morning of Monday, July 8." This quotation is from a letter by T. E. Reed, meteorologist, United states Weather Bureau, Binghamton, who was spending his racation at Hector at the time of the storm.

Watkins Glen, N. Y. - About 6 miles northwest, near Hall's Corners, a farmer left a straight-sided cream pail in an open place in his jard about noon on Sunday, July 7 , and on Mondey morning he noted. that it was filled with water up to the rivets fastening the handles on the pail. The writer measured this depth to be 7 inches, which the farmer stated was caught between noon July 7 and 9 a.m. July 8 . 
Ithaca, N. Y. - "At one place about 6 miles west and 3 miles north from Ithaca a can with straight sides showed a rainfall of approximately 9 inches for the sunday night rain previous to the peak of the flood. At a point about a mile west of the south end of Cayuta lake a farmer told me that a 10-quart pail which was empty the night before was full and overflowing the next morning. Near odessa another man had a milk bottle out which was full of water." From letter of J.P. Wells, consulting engineer, Rochester, N. Y.

Freeville, N. Y. - Albert B. Genung states that a straight-sided 5-gallon paint pail used to water his flowers was left empty in the garden on Sunday and found overflowing on Monday morning.

\section{Rochester was the only automatic rain-gage station to have}

record-breaking intensities for periods less than 2 hours. In the hour ending at $1 \mathrm{p.m}$. July 7 the gage recorded 0.91 inch in 10 minutes, 1.25 Inches in 15 minutes and 1.98 inches in 30 minutes. The maximum amounts previously recorded were 0.78 inch in 10 minutes, 0.99 inch in 15 minutes, and 1.70 inches in 30 minutes.

The following notes extracted from reports of cooperative observers of the United States Weather Bureau tell in the observers' own words the unusual intensity of this storm:

Alfred, N. Y. - J. Nelson Nomood, president Alfred Unfversity: "The terrific rain (indicated 5.58 inches) came during the night of July 7 and the morning of July 8 . *** The heaviest came between midnight and 7 o'clock in the morning, with intervals of little or no rain. Between $80^{\prime} \mathrm{clock}$ on Sunday evening and $80^{\prime} \mathrm{clock}$ on Monday morning the rain had amounted to 5.2 inches. The heaviest rains previously recorded here were in July 1920, when in the course of a regular tormado $3 \frac{1}{4}$ inches of rain came In 4 hours, and the other was in 1890, when a 24-hour rain amounted to 4.34 inches. The streams at this helght in the foothills of the Allegheny Mountains are mere creeks and most of the time have little or no water in them. They simply overflowed their banks and did terrific damage in the lower levels."

Cortland, N. Y. - Fred H. Crook: "Heaviest single shower in Cortland Monday, July 8 , at $4: 30$, brought $1 \frac{1}{2}$ inches in less than 30 minutes."

Delhi, N. Y. - H. L. Smith: "6 p.m. Sunday, July 7, unt1l $4 \mathrm{a} . \mathrm{m}$. Monday morning 8.1 inches of rain fell. It came down in torrents. I never experienced such a dowmpour in my ife."

Ovid, N. Y. - "For the week before July 6 there had been very little rainfali. Saturday night, July 6, about 8 p.m. a heavy rain beday, July 7, in the afternoon there were several thundershowers, the main parts of which went around us. Sunday night, July 7 , there were thundershowers all night. The greatest amount of rain foll between 3:00 a.m. and 7:00 a.m. of Monday. During this time about 6 inches fell. Between 3:00 a.m. and 4:00 a.m. the rain fell in virtual sheets-a cloudburst. I would estimate that during this hour about 3 inches fell."

Sharon Springs, N. Y. - W. M. Kling: "Fury of storm so great Sunday that rain dashing horizontaliy makes it certain that rainfall much greater than measurement." 3.21 inches of rainfall- was recorded between 6:30 and $7: 20$ p.m. on Sunday, July 7 . 


\section{FLOOD DISCHARGES}

General features

A series of extraordinarily severe thunderstorms during the night of July 7 and the morning of July 8, 1935, speedily brought many small streams to destructive helghts before the inhabitants could realize the seriousness of the situation in which they were caught. Consequently, many people were drowned or narrowly escaped with their lives, and there was generally no time for the protection of property, where that would have been possible.

The most intense run-off occurred along an east-west line extending from Hornell, on the Canisteo River, to Oxford, on the Chenango River, or generally along the boundary between the Susquehanna River Basin and the Finger lakes or Oswego River Basin. There were notable floods of less intensity near Chaumont, Jefferson County; in certain portions of the Mohawk Valley; on upper Schoharie Creek; on the Saw Kill near Kingston; on upper Esopus Creek; on the West Branch of the Delaware River near Delhl and Walton; and on Ouleout Creek in Delaware County.

Fortunately, the storm was confined to a comparatively narrow strip, which cut generally across the upper sources of main streams instead of extending longitudinally along any of them, as seemingly might have been possible. Had the latter occurred it is a matter of conjecture as to what greater helghts the main streams might have reached. The additIonal damage would undoubtedly have been enormous.

The precipitous hillsides characteristic of many drainage basins, the steep slopes of the small streams, the narrowness of the valleys, the Inability of the soll to absorb and store the rainfall, and the severity of the thunderstorms all contributed to the very rapid concentration and intensity of the run-off and to the severity of the destruction wrought by the small streams. Evidence of the almost incredible force of the mushing waters of these smaller streams is shown in plate $23, \mathrm{~A}$.

On the larger streams the flatter slopes and broader valleys caused the flood waters to assume less destructive velocities and to overflow the banks, thus causing less spectacular but very real loss by inundation as shown in plate $23, \mathrm{~B}$.

Figures 20 and 21 show the flood hydrographs based upon records of stage at principal gaging stations in the flood area. 


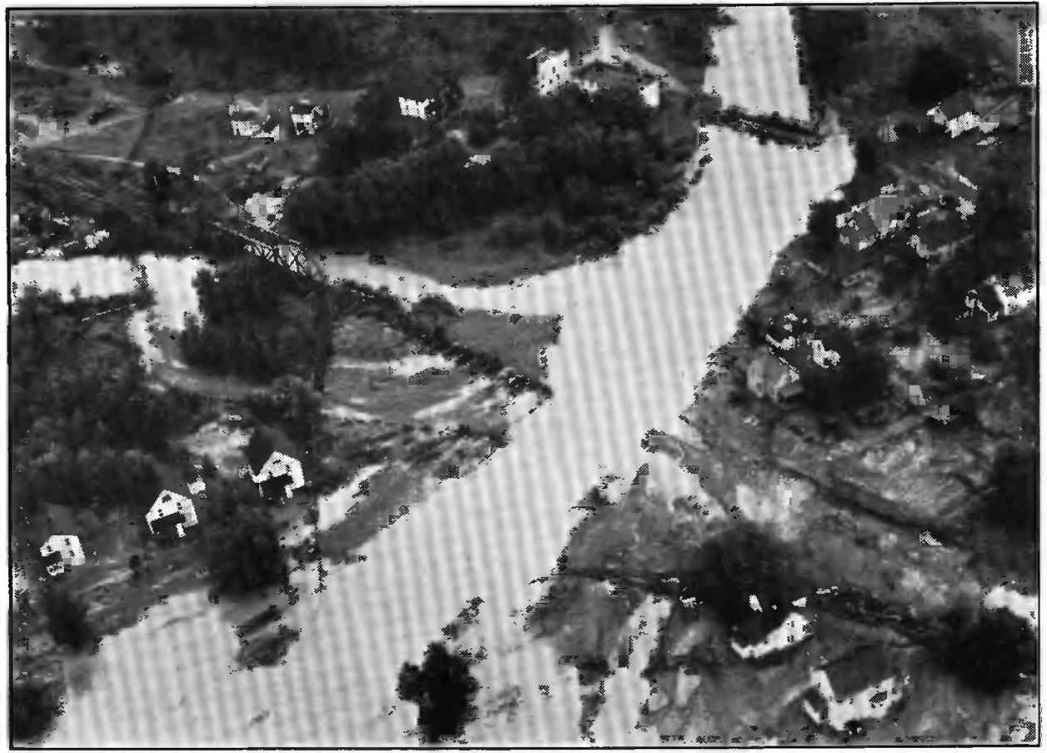

A. SALMON CREEK AT MYERS. N. Y., SHOWING FORCE OF THE FLOOD WATERS. Courtesy of "The News, New York's picture newspaper."

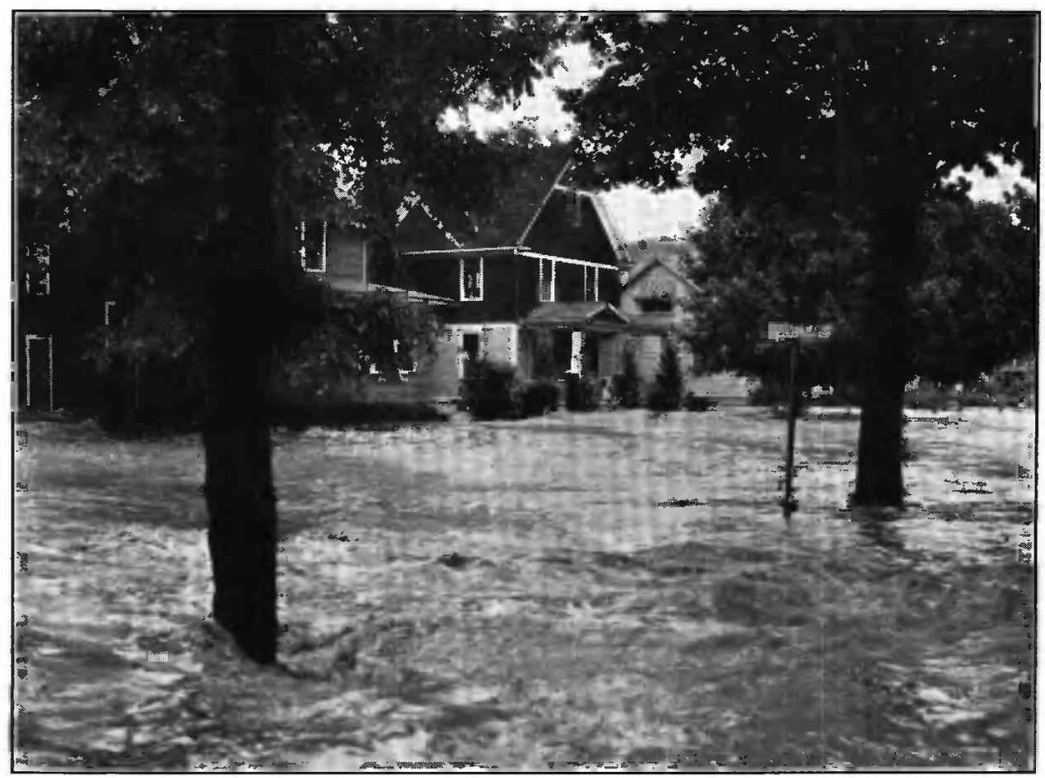

B. INUNDATION FROM CHENANGO RIVER, BINGHAMTON, N. Y. 

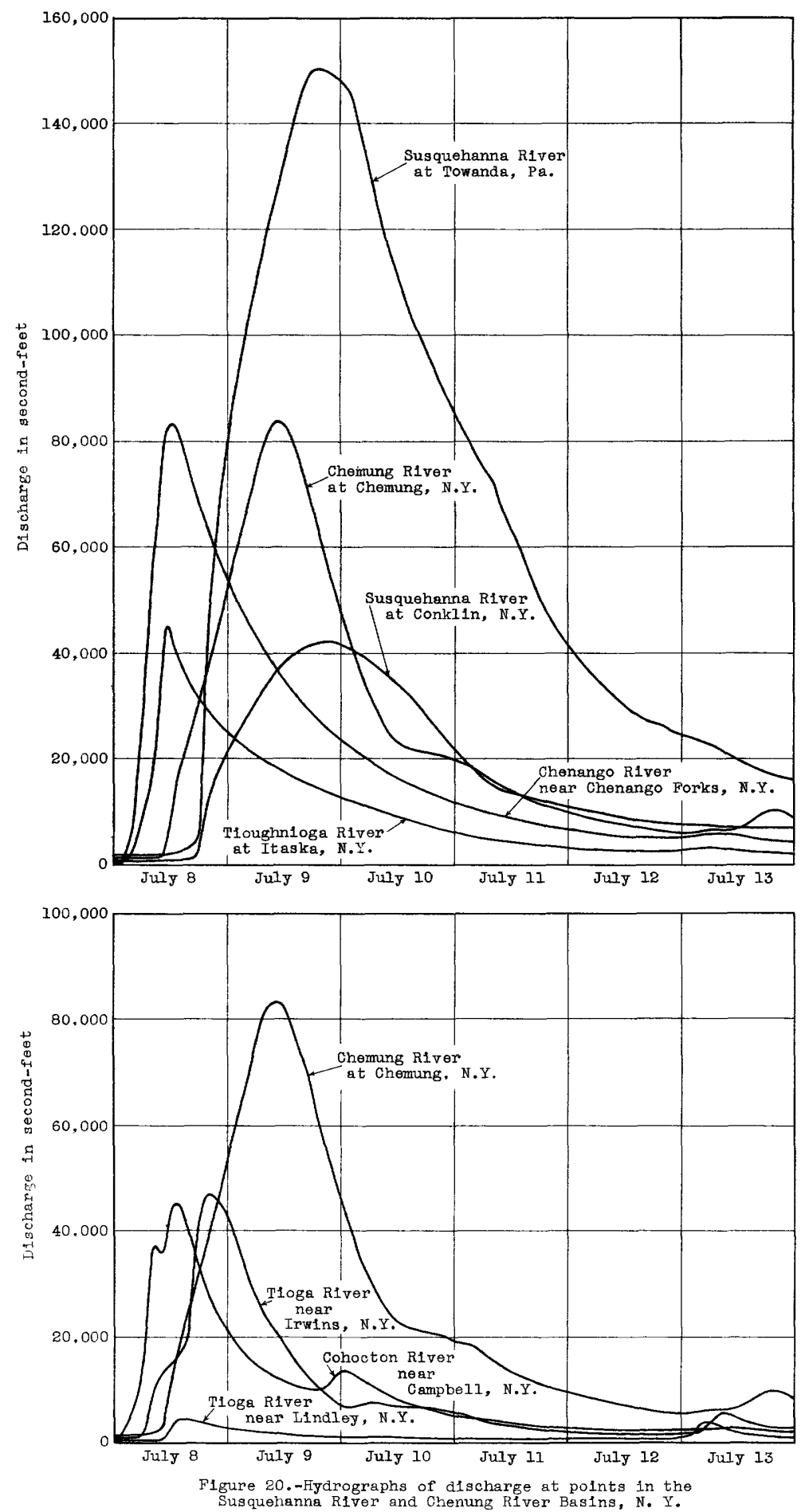


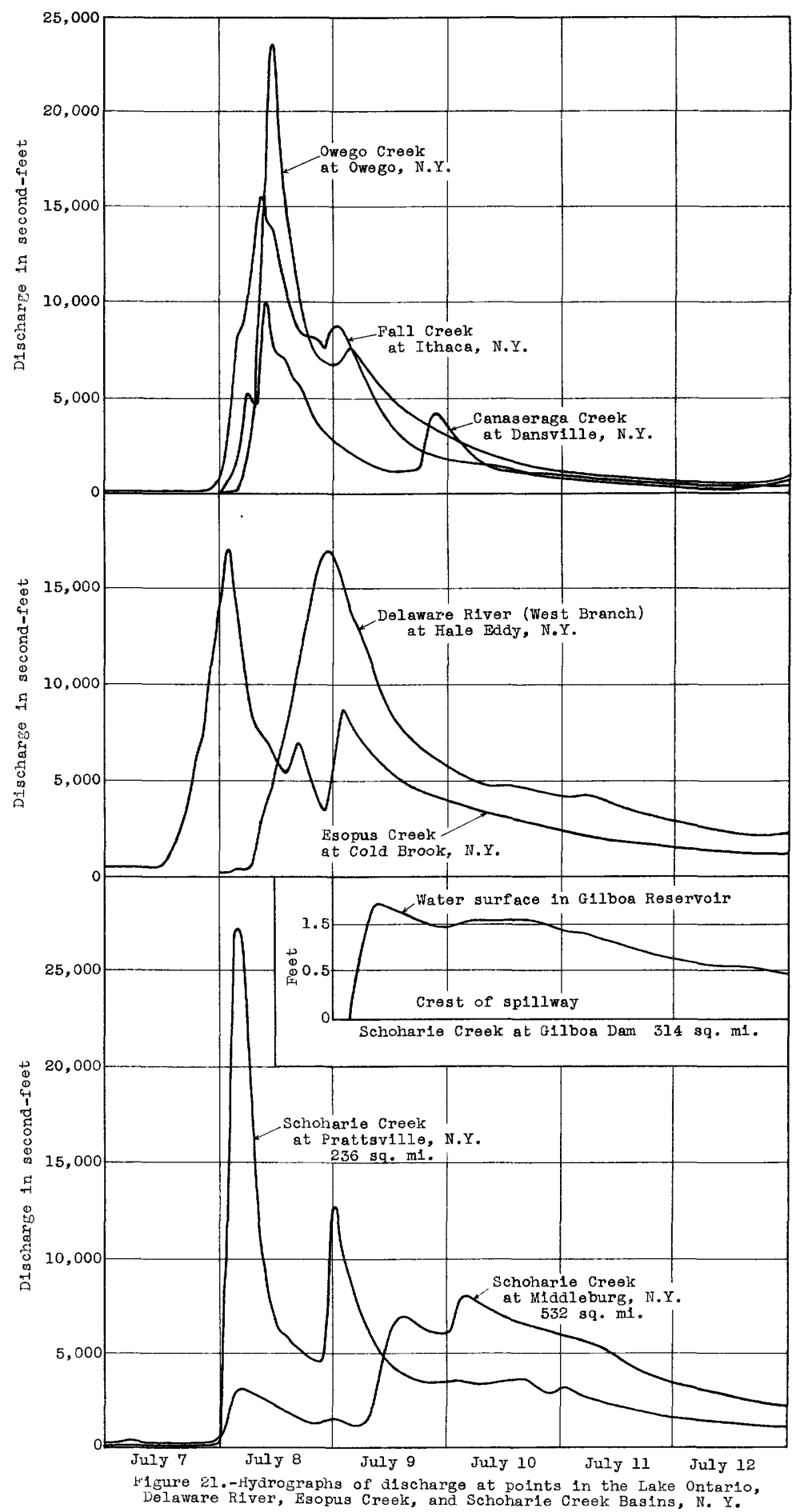


Unfortunately, within the areas of extraordinarily intense flood run-off there were no regular gaging stations at which intense discharges were recorded. Consequently, it has been necessary to obtain information of these discharges largely from special fleld surveys. The results obtained are valuable, but, no matter how palnstakingly obtained in the field and how carefully interpreted, they cannot approach in accuracy and completeness the data that might have been obtained at regularly established stream-gaging stations.

As the most intense discharges occurred largely on the smaller streams in a widespread area, it was desirable to make many determinations of the flood discharges by the best avallable methods in order to insure comprehensive information over the flood area.

\section{Fleld work}

Obstacles met in obtaining funds for the work delayed the start of the field activity until September 18. The writer, with an officiel car, was detalled from the district office of the United States Geological Survey at Albany, N. Y., to the fleld work, which was completed November 1. Fleld assistants were furnished by the Flood Control Survey, Corps of Engineers, U. S. Army, and by the New York State Department of Public Works.

A thorough reconnalssance of the flood area was first made by driving over the roads, walking up and down the streams where necessary, and selecting places on the streams at which it was believed satisfactory determinations of the flood discharge could be made from the evidence of the stages of the water surface, slopes, and other pertinent data. Sufficlent data were obtained in the fleld to allow the computation of the flood discharge by one or more methods dependent upon established hydraulic formulas and experience in their application. From these data were made 55 determinations of flood discharge--26 by the slope-area method, 22 over dams, 3 over falls, 1 through drops, and 3 through culverts.

In selecting a reach of channel at which a slope-area determination of discharge was to be made, the following factors were considered and the best possible selection made:

Stralghtness of channel.

length of reach.

Uniformity of cross section and slope.

Absence of trees, brush, and other obstructions.

Permanence of channel during flood.

Approach and get-away conditions.

Quality and quantity of high-water marks.

$566350-36-2$ 
At each site of a slope-area measurement a stadia survey was made, locating high-water marks on each bank for a considerable distance above and below the reach. Cross sections were taken across the flood channel at each end of the reach; on certain streams an additional cross section was taken near the center of the reach. Great care was exercised in the selection of the high-water marks, to insure that they represented the water surface and not an energy grade line of the stream, as indicated by the helght to which waves had washed or drift had been thrown. For this reason highwater marks on the ground, where wave action and run-up were believed to be a minimum, were generally selected in preference to high-water marks on trees and bushes as defined by debris, which may have been carried up by wave action or by the velocity of the current to a level above the prevailing water surface.

In selecting dams, fells, drops, or culverts only those were considered whose crests, profiles, and cross sections were sufficiently regular to allow their characteristics of discharge to be satisfactorily defined by formulas and coefficients whose applicability to similar structures had been determined by previous investigations. At such sites sufficlent high-water marks were taken nearby to define the head on the crests or openings. The structures were measured, and sufficient data were obtained for determining profiles and cross sections at the highest flood stage. The presence of possible backwater or submergence from below was investigated. Notes on conditions affecting the velocity of approach were made.

Photographs were generally taken at each polnt of measurement, and notes were made as to the character of the bed and banks of the channels and any other conditions that might be pertinent to a particular measurement.

Office preparation of fleld data

The data obtained in the field were plotted, and for most measurements the following sheets of data were made and checked:

1. A nup or sketch to scale, showing layout of channels, stmuctures, etc., with relative location of high-water marks.

2. A longitudinal profile showing the location of the highwater marks from which was determined the water-surface slope of the stream or the head on the structures. 
3. Cross sections of the channels and of the structures through or over which the water flowed.

4. For the slope-area measurements, sheets with the computation of the area and hydraulic radius of each section.

Assumptions and computations

The application of formalas and coefficients used in the computation of the flood flows was made with a full appreciation of the limitations of scientific knowledge of the behavior of streams under unusually extreme conditions, such as those of the July flood, and is believed to be consistent with good engineering judgment. Many of the streams undoubtedly carried enormous quantities of debris. The effect of this debris upon the applicability of the laws and formulas generally accepted as governing the flow of water is problematic. The same statement applies to the effects of sediment, entrained alr, turbulence, excessive slopes and velocities, and other factors, which occurred in a degree far outside the fleld of ordinary experiment and experience. In an unpublished manuscript Harold C. Troxe11, associate engineer, United States Geological Survey, describes the enormous debris movement that occurred during the flood of Jamary 1 , 1934, In La Cañada Valley, near Los Angeles, Calif. There the debris apparently moved downstream in a succession of waves, at velocities much slower than the water velocities, first filling up the stream channel and then being scoured out, creating unstable channel conditions that made it almost impossible to determine the discharge of water with any degree of accuracy. The field investigations in the New York flood area disclosed no evidence that the debris movements during the flood of July 1935 were generally similar to those described by Mr. Troxell. Consequently it is belleved that, through the reaches selected for the determination of flood discharge, the debris moved downstream in such a manner as to cause very little if any reduction in apparent area or water capacity of the channels. For the purposes of this report it has been assumed that the water surface of the streams was represented by the high-rater marks indicated on the banks, that the channels as surveyed had remained substantially unchanged throughout the flood, and that the flow conformed to the laws of the flow of water expressed by the formulas selected for the determination of the particular flood discharge. The results thus obtained are believed to be In the most useful form and of such value in the planning of flood- 


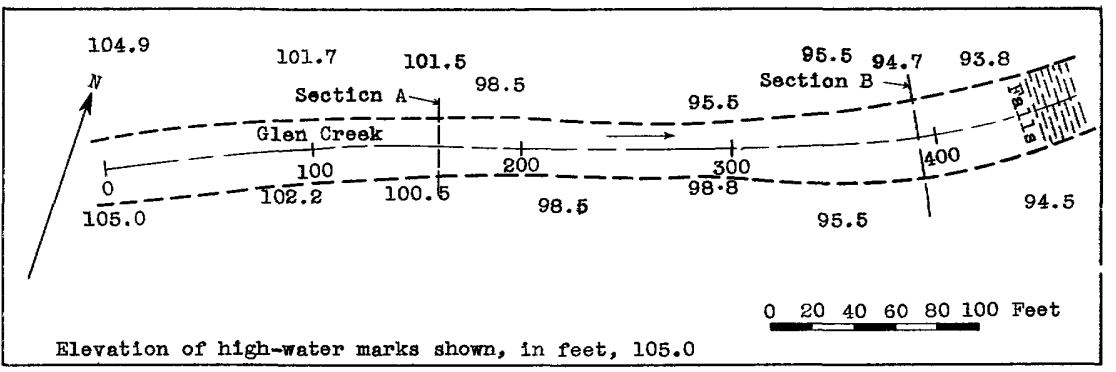
Sketch Map

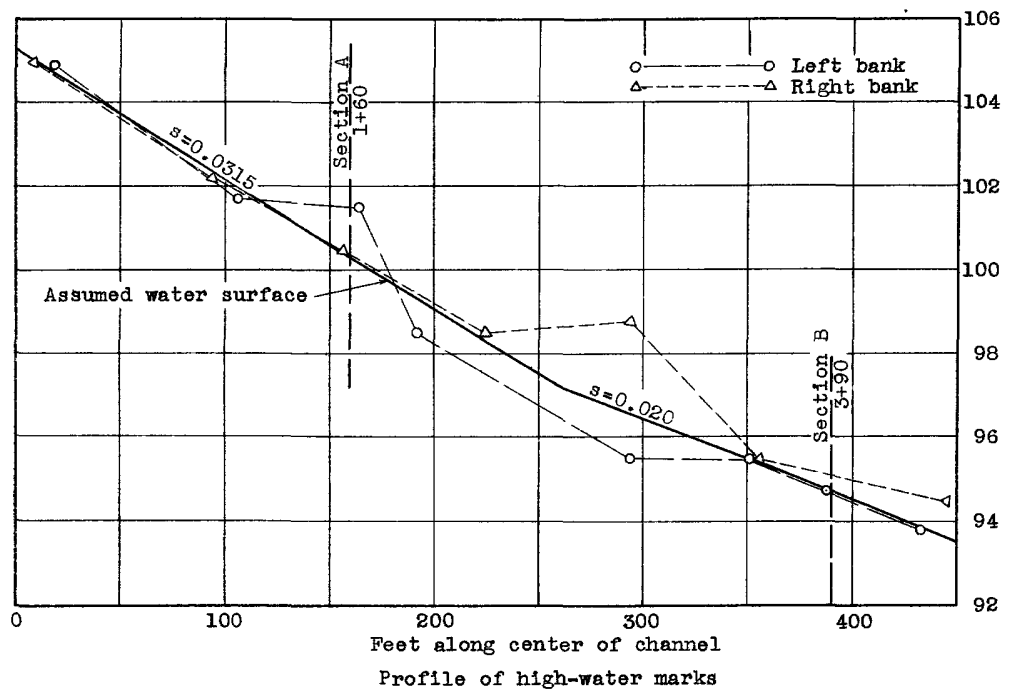

Section A

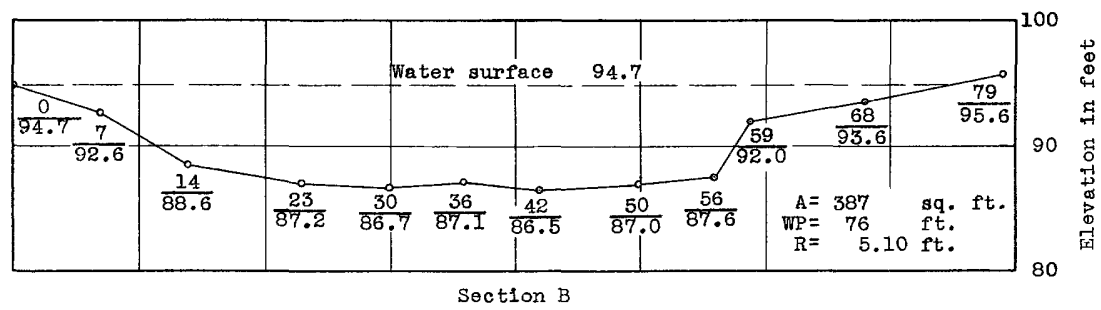

Flgure 22.-Map, profile, and sections of slope-area reach on Glen Creek near Townsend, N. Y. 


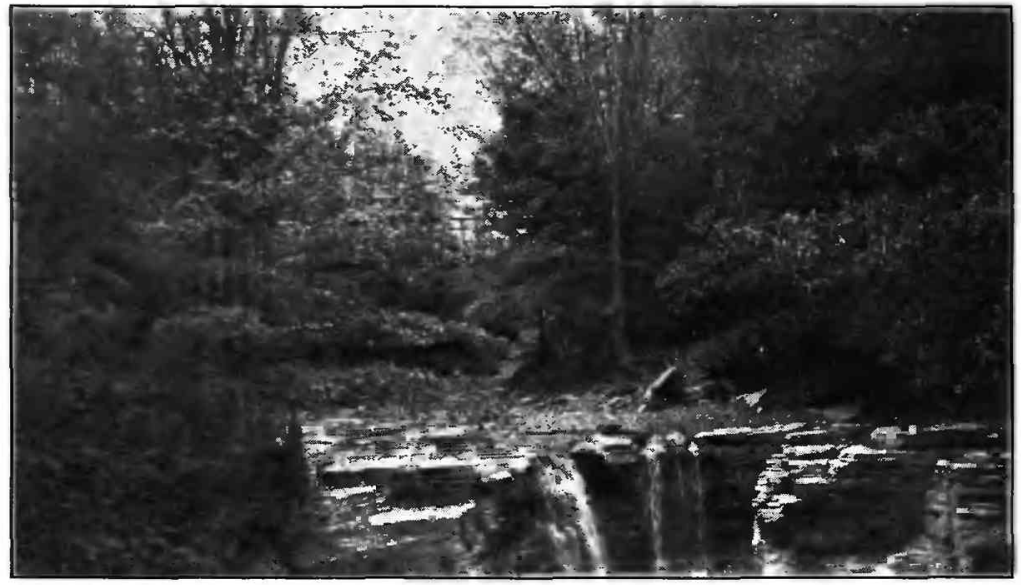

SLOPE-AREA REACH ON GLEN CREEK NEAR TOWNSEND, N. Y.

Looking upstream. Section B was taken about 50 feet above the falls, and section A was taken upstream, above the highway bridge. The bed of the creek at section A was composed chiefly of coarse gravel with a short section of ledge rock. At section $B$ the bed of the creek was flat, smooth shale. The right bank of the creek was shale of fairly regular section. The left bank was coarse stone and dirt and fairly uniform. Both banks contained brush and trees, which were generally above the high-water line. The falls shown in the picture were 8 to 10 feet high and were not submerged from below during the flood. The channel through the section has a slight curvature to the left. 


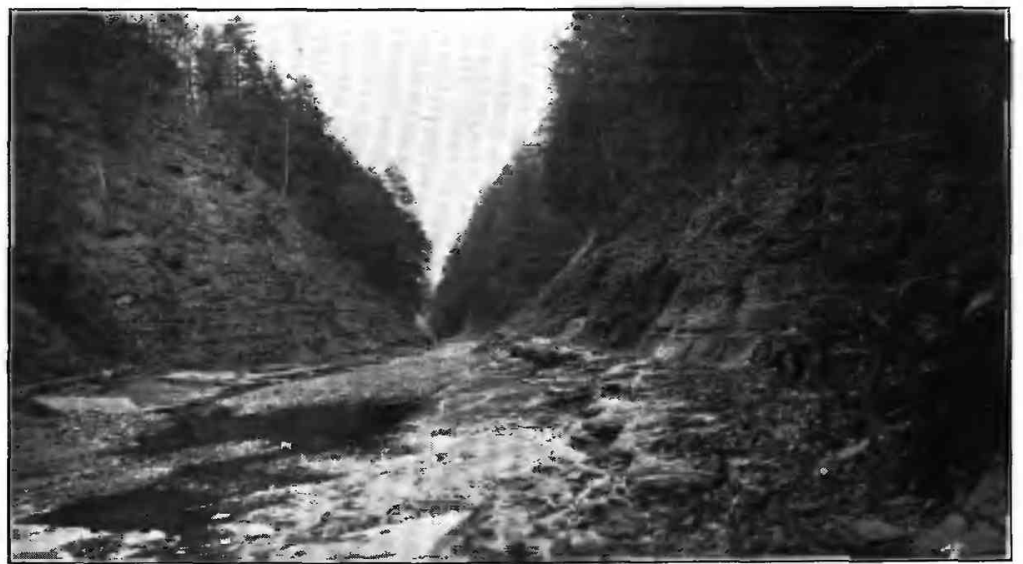

SLOPE-AREA REACH ON GLEN CREEK NEAR WATKINS GLEN, N. Y.

Looking downstream. Section A was taken in the foreground of the picture. Section $\mathbf{B}$ was taken at the bend where the man is standing. Section $C$ was taken near the end of the bare rock showing on the right bank. The bed of the creek was smooth, flat shale covered in spots by medium-sized gravel. Both banks were rock, steep, and, although rough, relatively uniform. There were no trees below the high-water line. About 75 feet below section tively uniform. There were no trees below the high-water line. About 75 feet below section
$\mathrm{C}$ there was a falls 10 to 12 feet high. There was no indication of submergence of the falls from below during the flood. 


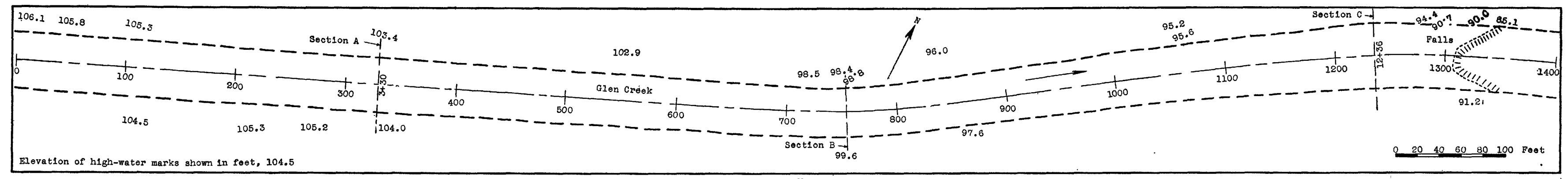

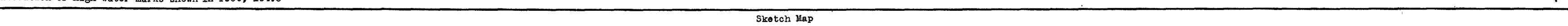
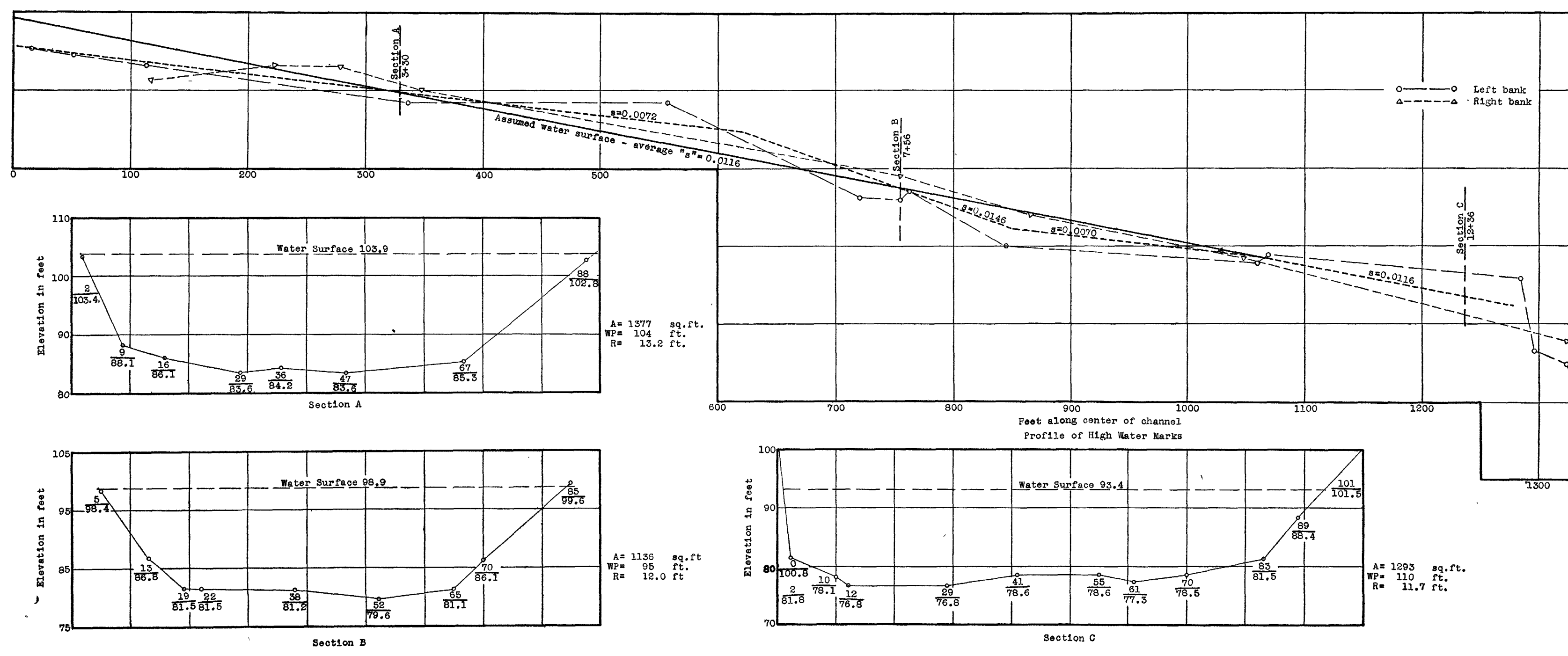

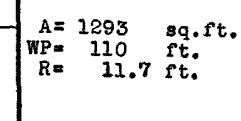

MAP, PROFILE, AND SECTIONS OF SLOPE-AREA REACH ON GLEN CREEK AT WATKINS GLEN, N. Y. 

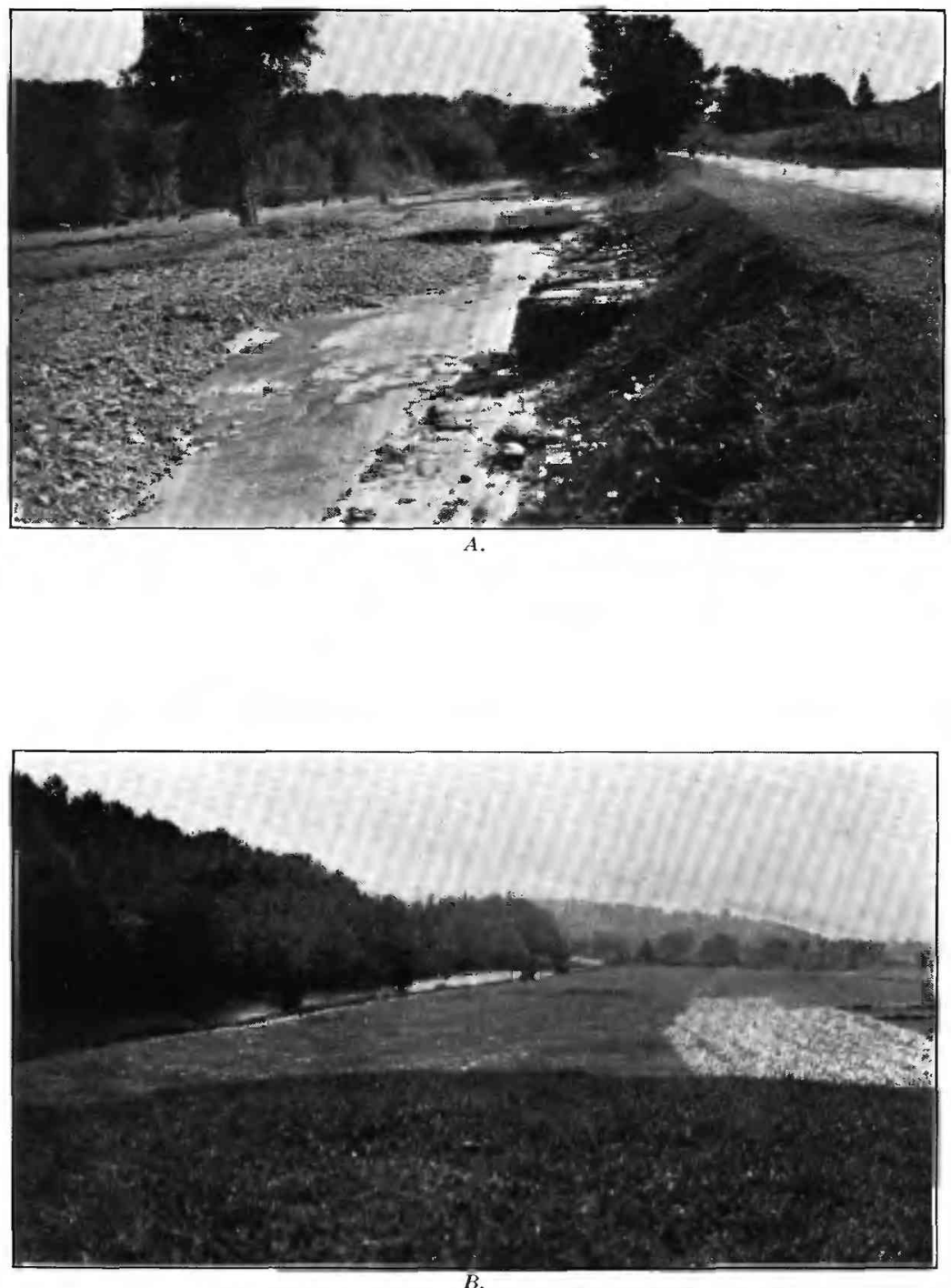

TYPICAL CHANNELS WITH " $n$ " ASSUMED FOR EACH.

In $A$ " $n$ " assumed 0.30 ; reach extended from large elm on left bank to barn on right bank. In $B$ " $n$ " assumed 0.030 for main channel and overflow on right bank, 0.100 for wooded section on left bank. 

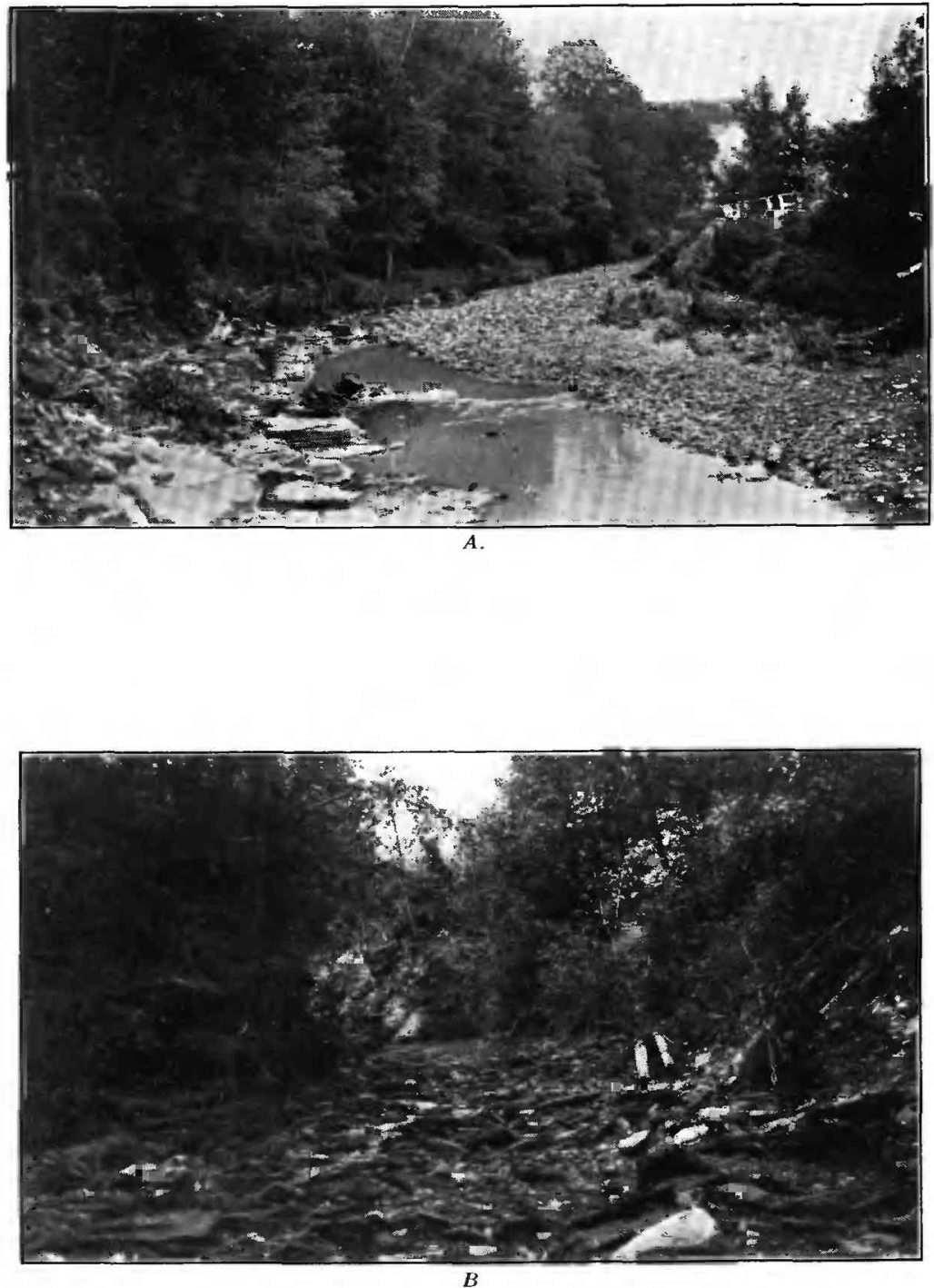

TYPICAL, CHANNELS WITH " $n$ " ASSUMED FOR EACH.

In $A$ " $n$ " assumed 0.035 for main channel, 0.100 for wooded flat shown at left of main channel. In $B$ "n" assumed 0.040 to 0.045 . 
protection measures as to rarrant their publication as the most reliable data that can be supplied. However, any user of the data is cautioned to keep in mind the method of derivation and to make such allowance therefor as may seem appropriate.

For the consideration of engineers who may wish to analyze critically the results showing outstandingly excessive rates of flow, there is shown on figure 22 and plates 24,25 , and 26 the basic information for two determinations of the flood flow of Glen Creek near Townsend and at Watkins Glen. Similar data for other determinations are on file and available to the public at the district office of the Geological Survey in Albany.

In computing the flood discharge by the slope-area method the average velocity was determined from the Manning equation

$$
\mathrm{V}=\frac{1.486}{\mathrm{n}} \mathrm{r}^{2 / 3} \mathrm{~s}^{1 / 2}
$$

in which $V=$ average velocity in the cross section

$\mathrm{n}=$ coefficient of roughness

$r=$ hydraulic radius

$s$ a surface slope

On plates 27 and 28 are shown pictures of typical channel sections with the assumed value of " $n$ ", the coefficlent of roughness, for each. The values of " $n$ " were selected and checked from the background of the Geological Survey's experience in such matters. Careful study was made of the pertinent data in a report by Ramser.* As the flow in most sections was not uniform, it was necessary to consider velocity head and to correct " $s$ " to a value representing the energy grade line. Where there was a recovery of energy head, it was assumed that the actual recovery was 50 percent of the theoretical recovery. Where the flow was confined to one channel, the correction was easily made. Where a section was considered to be composed of two or more channels with different " $n$ " and different " $r$ ", the weighted velocity head for the section was determined by an adaptation of the following equation given by O'Brien and Johnson**:

$$
\alpha=\frac{\Sigma \mathrm{V}^{3} \mathrm{da}}{\mathrm{V}_{\mathrm{m}}^{3} \mathrm{~A}}
$$

* Ramser, C. E., Flow of water in drainage channels; the results of experiments to determine the roughmess coefficient " $n$ " in Kutter's formula: U. S. Dept. Agr. Tech. Bull. 129, November 1929.

** O'Brien, M. P., and Jonnson, J. F., Velocity head corrections for hydraulic flow: Eng. News-Record, August 16, 1935. 
in which $\alpha=$ ratio of meighted velocity head to velocity head determined from the average velocity in the entire section.

$V=$ average velocity in any channel into which the entire section may be subdivided. $\mathrm{da}=$ area of any channel into which the entire section may be subdivided. $\Sigma V^{3} d a=$ summation of the product of $v^{3}$ and da for the channels into which the entire section may be subdivided.

$V_{m}=$ average velocity in the entire section.

$A=$ area of the entire section.

The flow over dams was computed by the formula

$$
\mathrm{Q}=\mathrm{CLH}^{3 / 2}\left(\mathrm{I}+0.56 \frac{\mathrm{H}^{2}}{\mathrm{~d}^{2}}\right)
$$

in which $C=$ coefficient depending largely on the shape of the crest. Values of $\mathrm{C}$ were selected from data in Horton, R. $\mathrm{E}$., Weir experiments, coefficients, and formulas, $2 \mathrm{~d}$ ed. J. S. Geol. Survey Water-Supply Paper 200, 1907.

$I=$ length, in feet, of the crest.

$H=$ head, in feet, on the crest of the dam.

$d=$ depth, in feet, of the approach channel.

Where necessary, allowance was made for submergence of the crest by water below the dam.

The flow over highway embankments was considered analogous to that over dams, and values for the coefficient $C$ were selected from experimental data by Yarnell and Nagler.*

The flow over falls was computed by the following formula**:

$$
Q=5.67 \text { LE } 1.5
$$

The results from this method were not very satisfactory. The steep slopes of the mater surface in the channels above the falls caused velocities greater than the critical velocity at the falls section and thus made the fall section ineffective as a control.

\footnotetext{
* Yarnel1, D. L., and Nagler, F. A., Flow of flood mater over railmay and highway embankments: Public Roads, April 1930.

* King, H. W., Handbook of hydraulics, 2d ed., p. 333, 1929.
} 


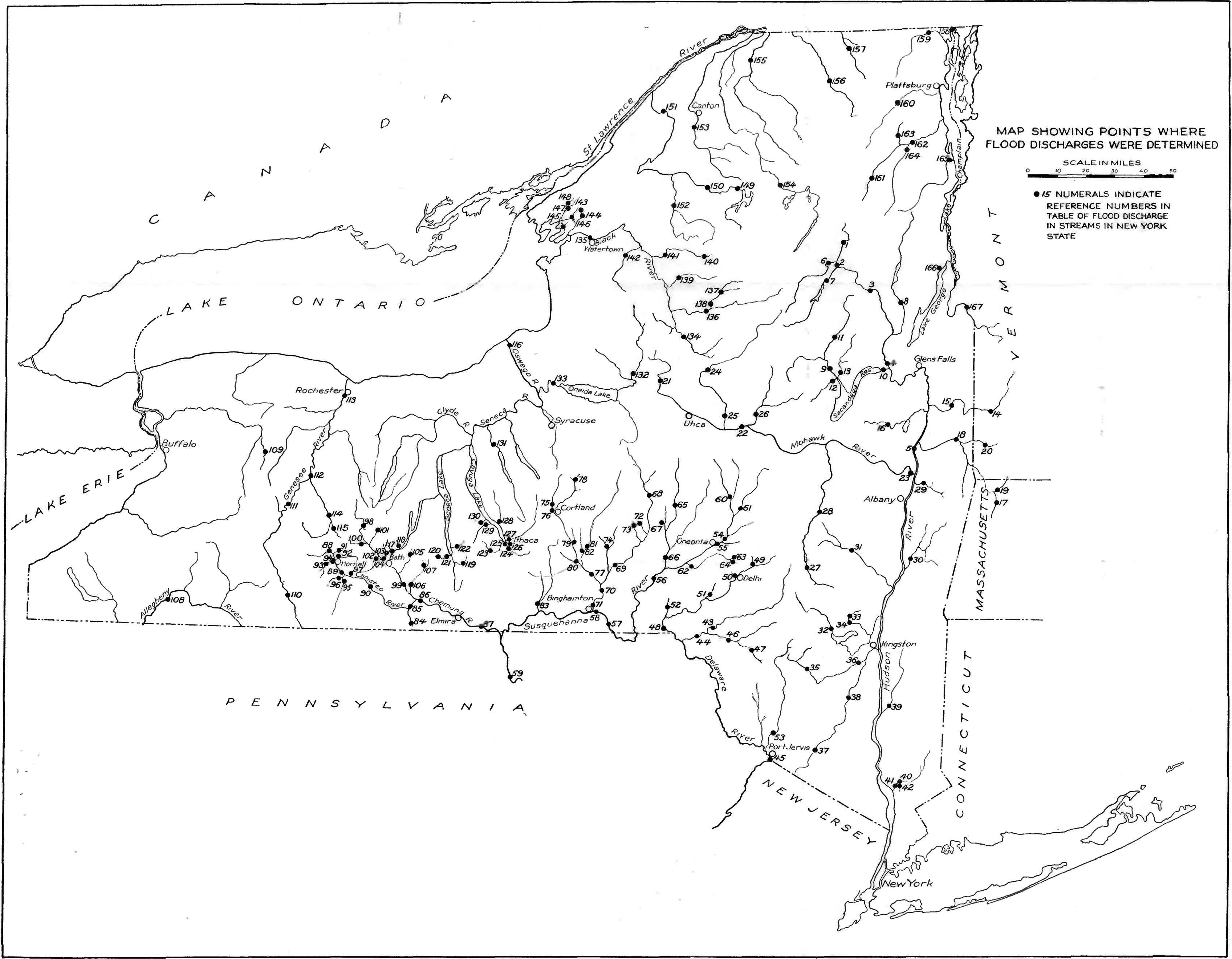


The flow through drops was computed by the following formula*:

$$
Q=3.62 \mathrm{LH} 1.47\left(1+0.44 \frac{\mathrm{a}^{2}}{\mathrm{~A}^{2}}\right)
$$

In which $a=$ cross-sectional area of the drop or notch.

$A=$ cross-sectional area of the approach channel.

The flow through culverts was computed by assuming that the available head was used in overcoming frictional losses in the culvert and in creating velocity.

All notes, photographs, plans, profiles, cross sections, and computations have been bound and are being kept as a permanent record.

Flood-discharge records

The table "Flood discharges of the streams in New York State" shows the results of the determination of the flood flows at the gaging stations and other points on streams. Previous maximum recorded floods are included, for comparison. The locations of the points at which these flood determinations were made are shown on plate 29 and may be ident1fled by the corresponding number in the table. Many determinations are shown for streams that did not reach their previously recorded flood flows in July, in order to compare the unprecedented flood flows occurring at that time with the flood flows previously recorded throughout the state.

The time of occurrence of the maximum discharges is not shown for many of the determinations. Most people were too busy seeking safety or trying to protect their property to record the time of the occurrence except roughly as the night of July 7 or the morning of July 8 .

*King, H. W., Handbook of hydraulics, lst ed., p. 143, 1918. 
Flood discherges of streams in New York State

\begin{tabular}{|c|c|c|c|c|c|c|c|c|c|c|c|}
\hline \multirow{3}{*}{$\begin{array}{l}\text { No. } \\
\text { on } \\
\text { map }\end{array}$} & \multirow{3}{*}{ Stream } & \multirow{3}{*}{ Point of mesurement } & \multirow{3}{*}{ dounty } & \multirow{3}{*}{$\begin{array}{l}\text { Period } \\
\text { of } \\
\text { rocord }\end{array}$} & \multirow{2}{*}{\multicolumn{2}{|c|}{$\begin{array}{l}\text { Uaximum discharge } \\
\text { previously recorded }\end{array}$}} & \multirow{3}{*}{$\begin{array}{c}\text { Drainage } \\
\text { area } \\
\text { (square } \\
\text { miles) }\end{array}$} & \multicolumn{4}{|c|}{ Marimum discharge during flood of July 1936} \\
\hline & & & & & & & & \multirow[b]{2}{*}{ Time } & \multicolumn{2}{|c|}{ Second-feot } & \multirow{2}{*}{$\begin{array}{c}\text { Method } \\
\text { of } \\
\text { determination }\end{array}$} \\
\hline & & & & & Date & $\begin{array}{c}\text { Second- } \\
\text { foet }\end{array}$ & & & Total & $\begin{array}{c}\text { Per } \\
\text { sq. mi. }\end{array}$ & \\
\hline & Hudson River Basin & & & & & & & & & & \\
\hline 1 & Hadson River & Hear Nowcomb, N.Y. & Besex & 1925-1935 & $\Delta \mathrm{pr} .9,1928$ & 6,250 & 192 & July $10,4 \mathrm{am}$ & 970 & 5.0 & Rating curve \\
\hline 2 & Hadson River & Gooley, N.Y. & Bssex & $1916-1935$ & $\Delta$ pr.12,1922 & 13,900 & 419 & July $9,11 \mathrm{am}$ & 2,680 & 6.4 & Rating ourve \\
\hline 3 & Hudson Biver & Horth Creek, N.Y. & Warren & $1907-1935$ & Mar.27,1913 & 27,400 & 792 & July $9,1 \mathrm{pm}$ & 26,920 & 8.7 & Rating curve \\
\hline 4 & Hudson River & Hadley, H.Y. & Saratoge & $1921-1935$ & $\Delta \mathrm{pr} .12,1922$ & 33,100 & 1,664 & July $9,2 \mathrm{pm}$ & all, 300 & 6.9 & Rating curve \\
\hline 5 & Hads on River & Heohanfertille, X.Y. & Saratoga & $1887-1936$ & Har. 28,1913 & 220,000 & 4,500 & saly 8,11 am & 236,800 & 8.2 & Rating curve \\
\hline 6 & Cedar River & Hear Indian Lake, H.Y. & Essex & $1930-1935$ & Oct.7,1932 & 6,050 & 160 & July $9,9 \mathrm{am}$ & 1,650 & 10 & Rating curvo \\
\hline 7 & Indian RIver & Hear Indian Lake, H.Y. & Hamilton & $1900-1935$ & $\operatorname{Lar} .28,1913$ & 3,460 & 132 & Joly $13,6 \mathrm{pm}$ & 2989 & 7.5 & Rating ourve \\
\hline 8 & Sehroon RIver & Riverbank, N.Y. & Tarren & $1907-1935$ & $\operatorname{Mar} \cdot 28,1913$ & 10,400 & 527 & Jaly 11, Itoon & 1,950 & 3.7 & Rating ourve \\
\hline 9 & Sacandaga River & Hear Hope, K.Y. & Hamil ton & 1911-1935 & Har. 27,2913 & 32,000 & 491 & July 9,4am & 10,500 & 21 & Rating curve \\
\hline 10 & Sacandaga River & Conkingtille, K.Y. & Saratoga & $1932-1935$ & Dec.2,1932 & 6,700 & 1,044 & July $12,7 \mathrm{em}$ & $a 7,650$ & 7.3 & Rating curvo \\
\hline 11 & Sacandaga River (E.Br.) & Griffin, N.Y. & Hanil ton & $1933-1935$ & Apr. 17,1934 & 2,620 & 314 & Joly $9,6 \mathrm{am}$ & 3,310 & 29 & Rating curvo \\
\hline 22 & West Ston creek & Noer Horthurille, X.Y. & Hamil ton & $1933-1935$ & Aug.24, 1933 & 3,790 & 88 & July $8,4 \mathrm{am}$ & 5,060 & 58 & Bating curve \\
\hline 13 & East Stony Creek & Hear Horthrille, N.Y. & Hemiliton & $1933-1935$ & $\Delta p r .17,1934$ & 1,670 & 89 & July 8 , Ioon & 1,940 & 22 & Rating curve \\
\hline 14 & Battenk111 & Arlington, $\nabla t$. & Bennington & $1928-1935$ & Jan.10,1935 & 3,320 & 352 & July $7,12: 30 \mathrm{pm}$ & 3,710 & 24 & Rating ourve \\
\hline 15 & Battenkill & Battenville, N.Y. & Washington & $2922-1935$ & 110v. 4,1927 & 21,300 & 394 & $\operatorname{Julg} 8,3 \mathrm{pm}$ & 9,460 & 24 & Rating curre \\
\hline 16 & Rayaderosseras Creek & Hear West Milton, K.Y. & Saratoge & $1927-1935$ & Mar.16,1929 & 2,350 & 90 & July $8,6 \mathrm{am}$ & 2,730 & 30 & Ratins curvo \\
\hline 27 & Hoosic RIver & Ldams, Mass. & Berkshire & $1931-1935$ & $\operatorname{Jan} .9,1936$ & 1,110 & 46 & $J u d y 8,4 a m$ & 975 & 21 & Bating curve \\
\hline 18 & Hoosic RIVer & Hear Bagle Bridge, H.Y. & Rensselaer & $\begin{array}{l}1910-1922 \\
1923-1935\end{array}$ & Hov. 4,1927 & 29,800 & 510 & Julg $8,6 \mathrm{am}$ & 7,680 & 15 & Rating ourve \\
\hline 19 & Hoosic River (I. Br.) & Yorth Adams, Mass. & Bericshire & $1931-1935$ & Hov.19,1932 & 2,720 & 39 & July $8,4,30 \mathrm{am}$ & 1,180 & 30 & Rating curve \\
\hline 20 & Talloomsac Rlver & Jear Horth Benningtion, Vt. & Bennington & $1931-1935$ & Iov.19,1932 & 3,460 & 131 & July $7,10 \mathrm{am}$ & 3,120 & 28 & Rating curve \\
\hline
\end{tabular}




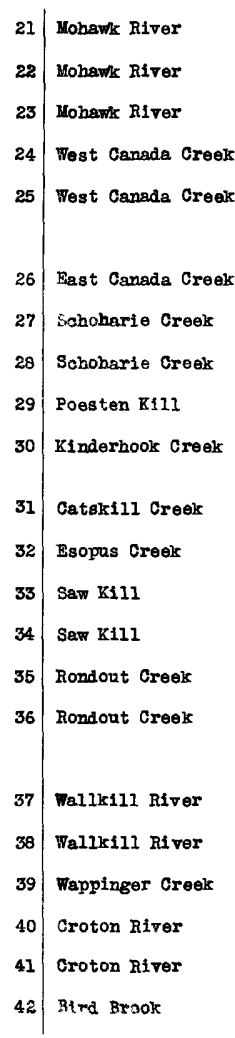

21 Mohawk River

22 Mohawk River

23 Noharke River

24 West Canada Creek

6) East Canada Creek

27 Sohoharie Creeks

28 Schoharie Creek

9 Poesten K111

Tinderhook Creak

31 Catskill Creek

32 Bsopres Creeir

33 Saw Kill

44 Saw Kil

35 Rondout Greek

Rondout Creok

37 Wallrill Rive

38 Wallkill River

39 Tappinger Creek

40 Croton River

42. Bind Brook
Below Delta Dam, K.Y.

Iear Little Falls, I.T.

Cohoes, H.Y.

Hinokley, H.Y.

Kast Bridge, I. Y.

Dolgeville, H.Y.

Prattsvilie, I.Y.

Midd lebarg, II. Y.

Mear Zroy, I.Y.

Rossman, H.Y.

Oevchill, X.Y.

Coldbrook, H.Y.

Ilear Shady, II. Y.

Iear Bearsville, I.Y.

Near Laokawack, M.Y.

Rosendale, I. Y.

Pellets Island Mounta1n, I.Y.

Gardiner, I.Y.

Ilear Wappinger Fa11s, II.Y.

Cornell Dam near Croton, H.Y.

Quaker Bridge, near Croton, M.T.

Quaker Briage, near Croton, I.Y.

\begin{tabular}{|c|c|c|}
\hline Onelda & b1919-1935 & Mar.9,1921 \\
\hline Herkimer & $1927-1935$ & Mar.15,1929 \\
\hline Albany & $1917-1935$ & Mar.16,1929 \\
\hline Oneida & 1919-1935 & $\mathrm{Apr} \cdot 12,1922$ \\
\hline Herkimer & $\begin{array}{l}\text { b1905-1910 } \\
\text { b1912-1913 } \\
\text { b1920-1935 }\end{array}$ & $\operatorname{Mar} .26,1913$ \\
\hline Herkimer & b1898-1935 & $\operatorname{Mar} .26,1913$ \\
\hline Greene & d1902-1935 & Mov.16,1926 \\
\hline Sohoharie & b1906-1935 & Pob.20,1909 \\
\hline Rensselaer & $1923-1935$ & \$or.4,1927 \\
\hline Columbla & $\begin{array}{l}1906-1914 \\
1928-1935\end{array}$ & Jan.22,1910 \\
\hline Grdene & e1910-1935 & \$ov.9,1913 \\
\hline U1ster & d)913-1935 & Ang.24,1933 \\
\hline Ulster & & \\
\hline U1st & & \\
\hline OIster & d1906-1935 & Ang.26,1928 \\
\hline Olster & $\begin{array}{l}1901-1903 \\
1906-1913 \\
1926-1935\end{array}$ & Arg: 27,1928 \\
\hline Orange & 1919-1935 & Mar.16,1920 \\
\hline OIste & $1924-1935$ & Sept.2,1927 \\
\hline Dutchess & $1928-1935$ & Mar.5,1934 \\
\hline Wes tohes ter & $1933-1935$ & $\operatorname{dax}, 5,1934$ \\
\hline ester & 1933-1935 & $2 \operatorname{sar} .5,1934$ \\
\hline Westab & $1933-1935$ & May 3,1934 \\
\hline
\end{tabular}

\begin{tabular}{|c|c|c|c|}
\hline 04,210 & 151 & July 8-9 & 84,030 \\
\hline 21,300 & 1,348 & July $8,8 \mathrm{pm}$ & a.17,200 \\
\hline 72,000 & 3,456 & July $8,11: 30 \mathrm{am}$ & 045,600 \\
\hline 10,800 & 375 & July $9,6 \mathrm{pm}$ & 25,380 \\
\hline 23,300 & 556 & Jaly $8,4: 30 \mathrm{pm}$ & alo, 300 \\
\hline 014,500 & 261 & July $8,9 \mathrm{pm}$ & 5,870 \\
\hline $\mathrm{d} 42,300$ & 236 & July 8 , & d27,200 \\
\hline c31,600 & 532 & July $10,48 m$ & as, 000 \\
\hline 7,030 & 89 & July $8,9 \mathrm{em}$ & 519 \\
\hline 11,000 & 329 & July $8,1: 30 \mathrm{pm}$ & 2,030 \\
\hline d12,300 & 98 & July $10,3: 30 a m$ & 1,220 \\
\hline d55,000 & 192 & July $8,2 \mathrm{sm}$ & d.27,100 \\
\hline & d9.5 & & d9,180 \\
\hline & di2.1 & & d9,980 \\
\hline d26,715 & 100 & Juzy 9 , 2am & $\mathrm{d} 2,120$ \\
\hline 27,300 & 386 & July $8,3: 30 \mathrm{am}$ & 12,600 \\
\hline 8,350 & 385 & Jaly $13,10 \mathrm{am}$ & 1,030 \\
\hline 12,900 & 711 & July $11,5: 30 \mathrm{am}$ & 1,130 \\
\hline 5,950 & 182 & $501 \mathrm{y} 9,5 \mathrm{pm}$ & 75 \\
\hline 4,010 & £378 & Jaly 10,3pm & al. 5 \\
\hline 3,940 & B379 & $\mathrm{Ju2} / \mathrm{g} 20,3 \mathrm{pm}$ & a: \\
\hline 14 & 0.36 & Io peake & b \\
\hline
\end{tabular}

d Record fur nished by Iew York City Board of Water Supply.

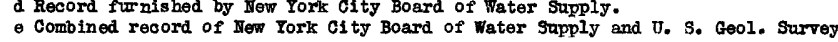

a.7, 200

45,600

10,300

5,870

200

, 000

519

1,220

7,100

9,980

, 120

2,600

, 030

130

a1.9

a3.2

Effective drainage area $0.40 \mathrm{sq} . \mathrm{mi}$
E Effective drainage area $1.74 \mathrm{sq}$. mi.

27 Rrting eurto

13

14 Rating curre

18 Rating ourve

22

ting ourve

5.8 Rating curve

6.2 Rating curre

12

Rating curve

slope-area

25 Slope-area

21 Rating ourve

33 Rating curve

2.7 Rating curve

1.6 Rating ourve

0.4 Rating ourve

4.6 Rating curve

1.9 Rating curve

0.5 Rating ouxve

h 0.19 second-foot on July 10, 3 pm 
Flood discharges of streams in Now York State--Continued

\begin{tabular}{|c|c|c|c|c|c|c|c|c|c|c|c|}
\hline \multirow{3}{*}{$\begin{array}{l}\text { No. } \\
\text { oni } \\
\text { max }\end{array}$} & \multirow{3}{*}{ Stream } & \multirow{3}{*}{ Point of measurement } & \multirow{3}{*}{ Corunty } & \multirow{3}{*}{$\begin{array}{l}\text { Period } \\
\text { of } \\
\text { record }\end{array}$} & \multirow{2}{*}{\multicolumn{2}{|c|}{$\begin{array}{c}\text { Maximum discharge } \\
\text { previously recorded }\end{array}$}} & \multirow{3}{*}{$\begin{array}{c}\text { Drainege } \\
\text { area } \\
\text { (square } \\
\text { miles) }\end{array}$} & \multicolumn{4}{|c|}{ Maximam discharge during flood of July 1935} \\
\hline & & & & & & & & \multirow[b]{2}{*}{ Time } & \multicolumn{2}{|c|}{ Second-feet } & \multirow{2}{*}{$\begin{array}{c}\text { Method } \\
\text { of } \\
\text { deternination }\end{array}$} \\
\hline & & & & & Date & $\begin{array}{c}\text { Second- } \\
\text { feet }\end{array}$ & & & Total & $\begin{array}{c}\text { Per } \\
\text { sq. mi. }\end{array}$ & \\
\hline 43 & $\begin{array}{c}\text { Delaware River Basin } \\
\text { Delaware River (E. Br.) }\end{array}$ & Harvard, ‥ T. & Delaware & $1934-1935$ & Mar. 6,1935 & 11,100 & 443 & July $8,2 \mathrm{pm}$ & 3,080 & 7.0 & Rating curve \\
\hline 44 & Delaware River (E. Br.) & Fishs Eddy, I.Y. & Delaware & $1912-1935$ & Ang. 24,1933 & 53,300 & 783 & July 8,4 pm & 3,360 & 4.3 & Rating curve \\
\hline 45 & Delaware River & Port Jervis, N.Y. & Orange & $1904-1935$ & Dot.10,1903 & 155,000 & 3,076 & July $9,2 \mathrm{pm}$ & 30,000 & 9.8 & Rating curve \\
\hline 46 & Beaver Kill & Cooks Falls, N.Y. & Delaware & $1913-1935$ & Aug.24,1933 & 17,800 & 241 & Jaly $9,8 \mathrm{am}$ & 640 & 2.6 & Rating curro \\
\hline 47 & Little Beaver Kill & Hear Livingston Hanor, N.Y. & Sollivan & 1924-1935 & Ang.26,1928 & 3,420 & 19.8 & July $8, x$ & 44 & 2.2 & Rating curvo \\
\hline 48 & Delaware River (w. Br.) & Hele Edy, Nor. & Delaware & $1912-1935$ & 0ot.10,1903 & 46,000 & 593 & Suly $8,11 \mathrm{pm}$ & 17,000 & 29 & Rating curve \\
\hline 49 & Wright Brook & Bloomville, N.?. & Delaware & & & & 11.2 & & 2,370 & 212 & Dam \\
\hline 50 & Steole Brook & Near Delht, N.Y. & Delaware & & & & 5.4 & & 2,850 & 528 & Dam \\
\hline 51 & Bast Oreak & Near Walt on, N. Y. & Delaware & & & & 23.5 & & 12,790 & 119 & Dam \\
\hline 52 & Cold Spring Brook & China, N.Y. & Delaware & & & & 1.65 & July $9,2 \mathrm{am}$ & 28 & 17 & Eating curro \\
\hline 53 & $\begin{array}{l}\text { Ievers ink River } \\
\text { Sasquehamns River Basin }\end{array}$ & Oakland Valley, N.Y. & Orange & $1928-1935$ & $\operatorname{sig} .24,1933$ & 20,000 & 222 & July 9,9am & 1,830 & 8.2 & Rating curre \\
\hline 54 & Susqueharns River & Collierstille, N.Y. & otsego & 1924-1935 & $\operatorname{Mar} .16,1929$ & 5,190 & 351 & July $9,2 \mathrm{am}$ & 23,020 & 8.6 & Rating curve \\
\hline 55 & Susquehanns River & Oneonta, … & otsego & $1907-1935$ & $\operatorname{Lar} .27,1913$ & j19.9 & & July $8,8 a m$ & $j 15.7$ & & \\
\hline 56 & Susquehanne River & Bainbridge, N. $\mathrm{Y}$. & Chenango & $1907-1935$ & $\operatorname{Mar} .29,1914$ & 921.1 & & July $8,12: 45 \mathrm{pm}$ & $j 18.7$ & & \\
\hline 57 & Susquehamna River & Conleclin, M.Y. & Broome & $1912-1935$ & Mar.28,1913 & 52,000 & 2,240 & July $9,9 \mathrm{pm}$ & 41,900 & 19 & Rating curve \\
\hline 58 & Susquehanna River & Binghamton, N.Y. & Broome & $1902-1935$ & Mar.2,1902 & jk19.74 & & July $9,3 \mathrm{am}$ & $j 17.7$ & & \\
\hline 59 & Susquehanns River & Towande, Pa. & Bradford & $1892-1935$ & $\operatorname{Lar} .17,1865$ & 188,000 & 7,797 & July 9,7 pom & 150,000 & 19 & Dating ourve \\
\hline 60 & Oaks Creak & Index, T. Y. & Otsego & 1929-1932 & $\Delta p r .12,1932$ & 1,060 & 103 & & 458 & 4.4 & Rating ourve \\
\hline 61 & Cherry Valley Creax & Near Vestrille, N.T. & Otsego & $1930-1931$ & $\Delta p r .11,1931$ & 1,780 & 81 & & 655 & 8.1 & Rating curve \\
\hline 62 & Ouleout Creak & East sianey, $\mathbf{H} . x_{0}$ & Delaware & & & & 101 & & $\$ 16,700$ & 165 & Dam \\
\hline
\end{tabular}




\begin{tabular}{|c|c|}
\hline 63 & Brook \\
\hline 64 & Brook \\
\hline 65 & Unadilla River \\
\hline 66 & Onadilla River \\
\hline 67 & Sage Brook \\
\hline 68 & Chenango River \\
\hline 69 & Chenango River \\
\hline 70 & Chenango River \\
\hline 1 & Chonango River \\
\hline 2 & Gilmore Brook \\
\hline 73 & Clear Brook \\
\hline 4 & Strongs Brook \\
\hline 5 & Tioughnioga Rivor \\
\hline 7 & Tioughnioga River \\
\hline 7 & Tioughnioga River \\
\hline 78 & Shackham Brook \\
\hline 79 & Willet Creek \\
\hline 80 & Dudley Croek \\
\hline 81 & Otselic River \\
\hline 82 & Morrill Croek \\
\hline 83 & Owego Creak \\
\hline 84 & Tioga River \\
\hline 8 & Tioga River \\
\hline$B 6$ & Chemung River \\
\hline
\end{tabular}

Near Meridale, N.Y. Hear Lored 1th, Nr.T.

Jear New Berlin, I.Y.

Rockdalo, N.Y.

Near South New Berlin, N.Y.

Sherburne, N.Y.

Greene, K.Y.

Hear Chenango Forks, N.Y.

Binghamt OZ, N. $Y$.

Near Preston, N.Y.

Preston, H.Y.

Near Smi thrille Flats, N.Y.

Homer, N.Y.

cortland, K.Y.

Itaska, $\mathrm{K} . Y$.

Noar Truxton, K.Y.

Warathon, N.Y.

Near Lislo, H.Y.

Near Upper Lisle, N.Y.

Near Opper Lisle, ․․

Hear Owego, N.Y.

Iindley, N.Y.

Hear Erwins, N.Y.

Corning, H.Y.

1 Probable flow when dam falled.

I Gage height in foet from 0 . S. Weather Buresu Records. k Equivalent gago hel ght 23.5 foet, Horch 17, 1865.

\begin{tabular}{|c|c|c|c|c|c|}
\hline Delaware & & & & 0.52 & \\
\hline Delaware & & & & 0.44 & \\
\hline Chenango & $1924-1935$ & Her. 15,1929 & 5,590 & 196 & Julg 8,5pm \\
\hline Chonango & $1929-1933$ & Dot.7,1932 & 10,400 & 518 & \\
\hline Chenango & $1932-1935$ & $\operatorname{sun} 19,1934$ & 23 & 0.69 & July 8,2pa \\
\hline Chenango & $1907-1935$ & Onknown & j11.2 & & July 8,3pm \\
\hline Chenengo & 1909-1929 & 1906 & $j 14.0$ & & Jaly 8,3pm \\
\hline Broome & $1912-1935$ & Ntar.27, 1913 & 35,500 & 1,492 & July $\theta$, soon \\
\hline Broome & $\begin{array}{r}1901-1911 \\
\text { J1933-1935 }\end{array}$ & Mar.2,1902 & m23.1 & & July 8,3pm \\
\hline Chenango & & & & 0.62 & \\
\hline Chenango & & & & 1.34 & \\
\hline Chenango & & & & 6.41 & \\
\hline Cortland & & & & 71.5 & \\
\hline Cortland & & & & 100 & \\
\hline Broome & $1929-1935$ & $\operatorname{Jan} .9,1935$ & 18,300 & 735 & July $8,11 \mathrm{am}$ \\
\hline Cortland & $1932-1935$ & $\operatorname{Mar} .31,1934$ & 57 & 3.12 & July 8,7pm \\
\hline Cortland & & & & 11.0 & \\
\hline Broomo & & & & 29.6 & \\
\hline Cortland & & & & 214 & \\
\hline Broome & & & & 20.8 & \\
\hline Tioga & $1930-1935$ & $\operatorname{Jan} .9,1935$ & 8,190 & 186 & July 8 , llam \\
\hline Steuben & $1930-1935$ & $\begin{array}{l}\text { Apr.1,1932 } \\
\text { Ang.24,1933 }\end{array}$ & 15,800 & 770 & July 8,2pm \\
\hline Steraben & $1918-1935$ & 22,1919 & 46,700 & 1,370 & July $8,8 \mathrm{pm}$ \\
\hline Steruben & $1909-1935$ & Mar. 14,1918 & Jn18.8 & & July 8,9pan \\
\hline
\end{tabular}

1 Former $\mathrm{V}$. S. Woather Bureau observer reported water 4.2 foet higher than observed during period gage was in operation.

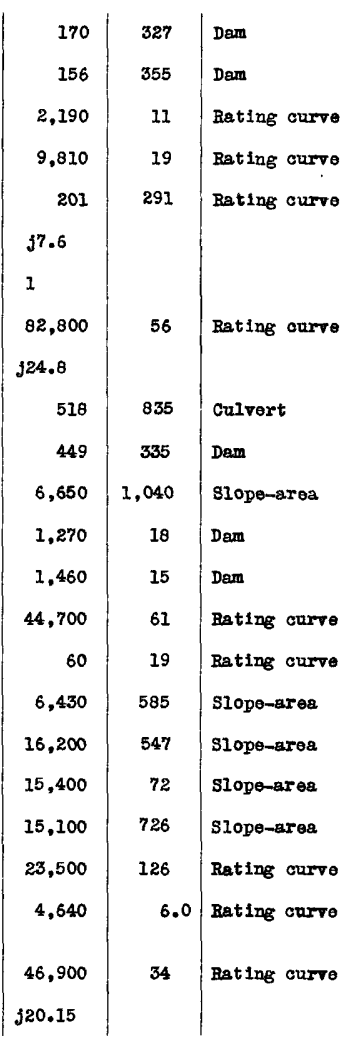

n Equivalent gage height 20.0 foet June $1,1889$. 
Food discharges of streams in New York State-Continued

\begin{tabular}{|c|c|c|c|c|c|c|c|c|c|c|c|}
\hline \multirow{3}{*}{$\begin{array}{l}\text { No. } \\
\text { on } \\
\text { map }\end{array}$} & \multirow{3}{*}{ Stream } & \multirow{3}{*}{ Point of measurement } & \multirow{3}{*}{ County } & \multirow{3}{*}{$\begin{array}{l}\text { Perlod } \\
\text { of } \\
\text { record }\end{array}$} & \multirow{2}{*}{\multicolumn{2}{|c|}{$\begin{array}{l}\text { Maximum discharge } \\
\text { previously recorded }\end{array}$}} & \multirow{3}{*}{$\begin{array}{c}\text { Drainage } \\
\text { area } \\
\text { (square } \\
\text { miles) }\end{array}$} & \multicolumn{4}{|c|}{ Maximum discharge during flood of July 1935} \\
\hline & & & & & & & & \multirow[b]{2}{*}{ Time } & \multicolumn{2}{|c|}{ Second-feet } & \multirow{2}{*}{$\begin{array}{c}\text { Yethod } \\
\text { of } \\
\text { determination }\end{array}$} \\
\hline & & & & & Date & $\begin{array}{l}\text { Second- } \\
\text { foet }\end{array}$ & & & Total & $\begin{array}{c}\text { Por } \\
\text { sq. mi. }\end{array}$ & \\
\hline & Delaware River Basin-Cont. & & & & & & & & & & \\
\hline 87 & Chemang RIver & Chemrang, I.Y. & Chemring & $1903-1935$ & Mar. 25,1918 & 67,000 & 2,530 & July 9,10 an & 83,400 & 33 & Rating curve \\
\hline 88 & Canlsteo River & Arkport, N.Y. & Steuben & & & & 30.4 & & 4,820 & 159 & Slope-area \\
\hline 89 & Canist eo River & Canisteo, N.Y. & Steuben & & 1902 & 09,570 & 185 & & 025,000 & 135 & Slope-area \\
\hline 90 & Canlsteo River & Wost Camaron, H.Y. & Steuben & $2930-1931$ & Mag 24,1931 & 4,000 & 344 & & 35,000 & 102 & Slope-area \\
\hline 91 & Carrington Creek & Fremont Genter, N.Y. & Stenben & & & & p13.6 & & p3,750 & 276 & Dam \\
\hline 92 & Big Crook & Near Horth Hornall, M.Y. & Steaben & & & & 16.5 & & 11,900 & 721 & slope-area \\
\hline 93 & Canacadea Creek & Llmond, N.Y. & Steuben & & & & 49.8 & & 22,000 & 442 & Slopemares \\
\hline 94 & Canacadea Creak & Hornoll, N.Y. & Steuben & 1924-1929 & Nov.30,1927 & 4,610 & 59.4 & & 26,600 & 448 & slope-area \\
\hline $\mathrm{sis}$ & Bennett Creelr & Near Canisteo, N.Y. & St exben & & & & 72.5 & & 012,400 & 173 & slope-area \\
\hline 98 & Purds Cregk & Near Conisteo, N.Y. & Steuben & & & & 21.2 & & 08,990 & 424 & slope-area \\
\hline 97 & Stephens Creek & Near Carson, N.Y. & St euben & & & & 7.04 & & 6,700 & 952 & Dam \\
\hline 98 & Cohocton River & Near Cohocton, N.Y. & Steuben & & & & 44.0 & & 891 & 20 & Dam \\
\hline 99 & Gchocton River & Near Campbell, N.Y. & Steuben & 1918-1935 & Deo.1,1927 & 12,900 & 472 & July $8,1 \mathrm{pm}$ & 45,400 & 96 & Rating ourve \\
\hline 100 & Ne1l Creek & Bloomerville, I.Y. & Steuben & & & & $\mathrm{q} 20.8$ & & $q 5,040$ & 242 & Slope-area \\
\hline 101 & Tenmile Creek & Above West Greok, N.Y. & Steuben & & & & $q 5.96$ & & 91,510 & 253 & slope-area \\
\hline 102 & Campbell Croek & Near Kanona, N.Y. & Steuben & & & & $\mathrm{q} 35.8$ & & $q 14,000$ & 391 & Slope-area \\
\hline 103 & Harrisburg Hollow & Near Hickory HIll, N.Y. & Steuben & & & & 2.02 & & 2,220 & 1,100 & Slope-area \\
\hline 104 & Harrisburg Hollow & Near Hlckory HIll, N.Y. & Steuben & & & & 2.49 & & 2,810 & 1,130 & 81ope-area \\
\hline 105 & Brook & Bradford, N.Y. & Steuben & & & & 1.68 & & 1,940 & 1,150 & slope-area \\
\hline 106 & Meads Creek & Fast Campbell, N.Y. & Steuben & & & & 46.1 & & 30,300 & 657 & Slopo-area \\
\hline 107 & Pine Creek & INear Monterey, N.Y. & Sohuylex & & & & 5.00 & & 3,270 & 654 & slope-area \\
\hline
\end{tabular}


Allegheny River Basin

100 Allegheny River

Strosms tributary to

Lake Ontario

109 L1ttle Tonavanda Creok

110 Geneser River

111 Genesee River

112 Genesee R1ter

113 Genesee River

114 Cansseraga Crook

115 Stony Brookx

116 0swego River

117 Softwater croek

118 Glen Brook

119 Cat1in 4111 Greok

120 Glen Creek

121 Glen Creek

122 Greok

123 Fite vile Croek

124 Six Mile Creek

125 Six Mile Creek

126 Cascadilla Creek

127 Fall Creek
Red House, N.Y.

Linden, M.Y.

Sc10, N.Y.

St. Belena, N.Y.

Jones Bridge near Yount Morris, M.Y. Livingston

Rochoster, M.Y.

Noar Densville, N.Y.

Stony Brook Glen, N.Y.

Oswego, 11.Y.

Near Cold Springs, IN.Y.

Henmonds port, $\mathbb{X} . Y$.

Odessa, H.Y.

Hear Townsend, I.Y.

Watkins Qlen, N.Y.

Burdet $t, M_{0}$ Y.

Enfield, I. $Y$.

potters Falls, noar Ithroca, I. Y.

Van Lttas Dam, Ithaca, N. Y.

East Ithaca, M.Y.

Ithace, H.Y.

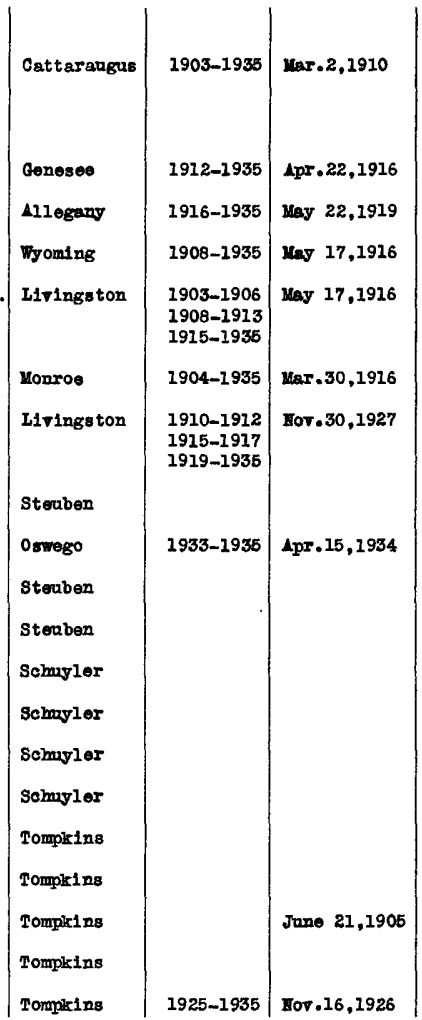

Wy

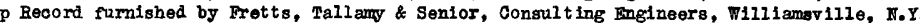

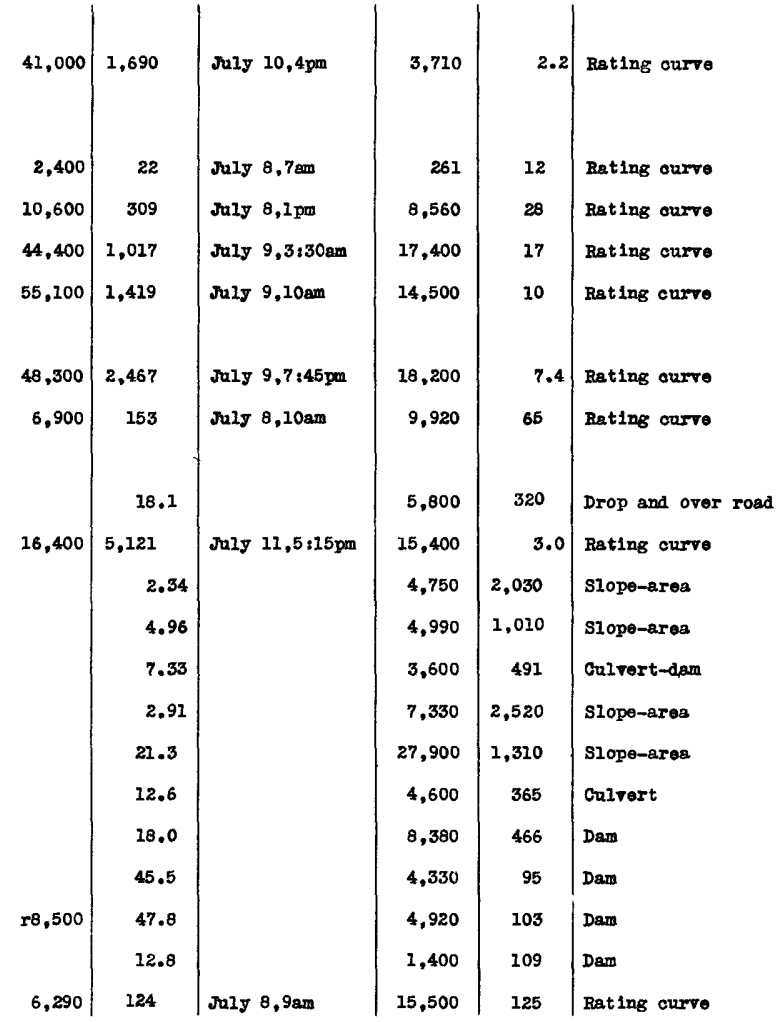


Flood discharges of streans in New York State--Continued

\begin{tabular}{|c|c|c|c|c|c|c|c|c|c|c|c|}
\hline \multirow{3}{*}{$\begin{array}{l}\text { No. } \\
\text { on } \\
\text { map }\end{array}$} & \multirow{3}{*}{ Stream } & \multirow{3}{*}{ Point of measurement } & \multirow{3}{*}{ County } & \multirow{3}{*}{$\begin{array}{l}\text { Perlod } \\
\text { of } \\
\text { record }\end{array}$} & \multirow{2}{*}{\multicolumn{2}{|c|}{$\begin{array}{l}\text { Maximum disoharge } \\
\text { previously reoorded }\end{array}$}} & \multirow{3}{*}{$\begin{array}{c}\text { Drainage } \\
\text { area } \\
\text { (square } \\
\text { miles) }\end{array}$} & \multicolumn{4}{|c|}{ Yaximum discharge during flood of Jaly 1935} \\
\hline & & & & & & & & \multirow[b]{2}{*}{ Time } & \multicolumn{2}{|c|}{ Second-feet } & \multirow{2}{*}{$\begin{array}{l}\text { Method } \\
\text { of } \\
\text { determination }\end{array}$} \\
\hline & & & & & Date & $\begin{array}{c}\text { Second- } \\
\text { feet }\end{array}$ & & & Total & $\begin{array}{c}\text { Per } \\
\text { sq. ml. }\end{array}$ & \\
\hline & $\begin{array}{l}\text { Streams tributary to } \\
\text { Lake Ontario-Gont. }\end{array}$ & & & & & & & & & & \\
\hline 128 & Selmon Creek & Myers, K.Y. & Tompkins & & & & 89.2 & & 18,500 & 207 & Slope-area \\
\hline 129 & Taughannock Creok & Near Halseyrille, К.Y. & Tompkins & & & & 56.7 & & 42,100 & 742 & Slope-area \\
\hline 130 & Trumansburg Creak & Trumans burg, N.Y. & Tompkins & & & & 11.5 & & 27,800 & 1,550 & slope-area \\
\hline 131 & Owasco Iake Outlet & Near Azburn, N.Y. & Cayuga & $1912-1935$ & $\operatorname{Mar} .29,1913$ & 2,750 & 208 & July $13,4: 30 \mathrm{pm}$ & 8800 & 3.8 & Bating curve \\
\hline 132 & Fish Creek & Taberg, K.Y. & Onelda & $1923-1935$ & oct.6,1932 & 16,500 & 189 & July $7,6: 30 \mathrm{pm}$ & 2,860 & 15 & Rating ourve \\
\hline 133 & Oneida River & Caughdenoy, N.Y. & Oswego & $1910-1935$ & Lar.30,1913 & $s 11,100$ & 1,377 & raly 11 & $8 t 2,450$ & 1.8 & Rating curve \\
\hline 134 & Black Rivor & Near Boonville, N.Y. & One1da & $1911-1935$ & Mar. 28,1913 & 10.000 & 295 & Jaly $9,2 \mathrm{pm}$ & 82.940 & 10 & Rating curve \\
\hline 135 & Blaok River & Watertown, N.Y. & Jefferson & $1920-1935$ & Apr. 9,1928 & 33,900 & 1,876 & July $11,6: 30 \mathrm{am}$ & a7,420 & 4.0 & Rating ourve \\
\hline 236 & Moose River & MoKeever, N.Y. & Oneida & $1900-1935$ & Mar. 27,1913 & 15,500 & 365 & July $9,6: 30 \mathrm{pm}$ & 1,780 & 4.9 & Rating curve \\
\hline 137 & Moose River (Mid. Br.) & Old Forge, N.Y. & Herkimer & $1911-1935$ & Mar. 23,1921 & 862 & 52 & July 9-13 & al87 & 3.6 & Rating ourve \\
\hline 238 & Moose River (Mid. Br.) & Near HoKeever, K.Y. & Herkimer & $1925-1935$ & $\Delta \mathrm{pr} .27,1926$ & 2,100 & 148 & July $10,7 \mathrm{pm}$ & 488 & 3.3 & Rating curve \\
\hline 139 & Independence River & Sperryville, N. Y. & Lew1s & $1927-1935$ & oct.6,1932 & 4,700 & 85 & Jraly $8,5 \mathrm{pm}$ & 525 & 6.2 & Rating curve \\
\hline 240 & Beaver River & Stillwater Dam, K.Y. & Herkimer & $1908-1935$ & May 3,1926 & 3,700 & 172 & July $8-9$ & 2581 & 3.4 & Rating ourve \\
\hline 141 & Beaver Rfver & Croghan, N.Y. & Lew1s & $1930-1935$ & Apr.19,1933 & 3,390 & 294 & July $9,3,30$ Am & 21,400 & 4.8 & Rating curve \\
\hline 142 & Deer R1ver & Copenhagen, K.Y. & Lewis & $1929-1935$ & Jan. 8,1930 & 4,500 & 89 & Juily $7,7 \mathrm{pm}$ & 1,200 & 14 & Rating curve \\
\hline 143 & Brook & Near Stone kills, K.Y. & Jefferson & & & & ul. 7 & July $7-8$ & u646 & 380 & Culvert and over road \\
\hline 144 & Brook & Stone Mills, K.Y. & Jefferson & & & & $u_{7.3}$ & July 7-8 & 22,460 & 337 & Culvert and over roed \\
\hline 145 & Brook & Near Guffins Bay, N.Y. & Jefferson & & & & ul.8 & July $7-8$ & u460 & 256 & Gulvert and over road \\
\hline 146 & Horse Creak & Near Depauville, N.Y. & Jefferson & & & & u4.1 & July $7-8$ & $\mathrm{ul}, 950$ & 476 & Culvert and over road \\
\hline 147 & Charmont River & Deprauville, N.Y. & Jefferson & & & & a22.7 & Joly 7-8 & $u 4,500$ & 198 & Culvert \\
\hline 148 & Brook & Near Depauville, K.Y. & Jefferson & & & & u4.7 & July 7-8 & ur, 020 & 217 & oulvert \\
\hline
\end{tabular}




\begin{tabular}{|c|c|c|c|c|c|c|c|c|c|c|c|}
\hline & $\begin{array}{l}\text { Streams tributary to } \\
\text { St. Lawrenoe Biver }\end{array}$ & & & T & & & & & & & \\
\hline 149 & Oswegatchie River (E. Br.) & Cranberry Lake, X.Y. & St. Lawrence & $1923-1935$ & $\Delta p r .1933$ & 1,620 & 144 & July $13-16$ & 2230 & 1.6 & Rating curve \\
\hline 150 & Oswegatchle River (E. Br.) & Near Oswegatohie, N.Y. & St. Lanrence & $1924-1935$ & Apr.6,1928 & 4,010 & 263 & July $7,10 \mathrm{pm}$ & 21,760 & 6.7 & Ratling ourve \\
\hline 151 & Oswegatchie River & Near Heuvel ton, I.Y. & St. Lawrence & 1916-1935 & Jan.11,1930 & 15,600 & 973 & July $11,7 \mathrm{am}$ & 4,270 & 4.4 & Rating ourve \\
\hline 152 & Oswegatchio River (w. Br.) & Near Harrisville, I.Y. & St. Lawrence & $1916-1935$ & Jan.9,1930 & 6,920 & 258 & Jurg $9,2 \mathrm{am}$ & 1,780 & 6.9 & Rating curve \\
\hline 153 & Grass River & Pyrites, N.Y. & St. Lawrence & $1924-1935$ & Yov.18,1927 & 8,300 & 335 & July $9,4 \mathrm{am}$ & 2,570 & 7.7 & Rating curve \\
\hline 154 & Raquet te River & Plercofield, X.Y. & St. Lawrence & $1908-1935$ & Apr.17,1922 & 7,580 & 722 & July $10,1 \mathrm{pm}$ & 1,330 & 1.8 & Rating curve \\
\hline 155 & St. Regis River & Brasher Center, M.Y. & St. Lawrence & $\begin{array}{l}1910-1917 \\
1919-1935\end{array}$ & Mar. 27,1914 & 16,200 & 616 & July $10,10 \mathrm{am}$ & 3,010 & 4.9 & Rating curve \\
\hline 156 & Salmon River & Chasm Falls, Y.Y. & Franklin & $1925-1935$ & Apr. 25,1926 & 2,890 & 132 & July $8,9 \mathrm{am}$ & 8156 & 1.2 & Rating curve \\
\hline 157 & Chaterugay River & Near Chat eaugay, N. Y. & Franklin & $1926-1935$ & Apr.8,1928 & 2,060 & 112 & July $8,4 \mathrm{pm}$ & a1.62 & 1.4 & Rating curve \\
\hline 158 & Richelieu River & Rouses Point, N.Y. & clinton & $1871-1935$ & Apr.2,1903 & $\operatorname{mo.60}$ & 8,277 & July 12 & $\mathrm{m3} .61$ & & \\
\hline 259 & Great Chazy River & Pesry Mills, N.Y. & clintion & $1928-1935$ & Mar.16,1929 & 5,810 & 247 & July $9,2 \mathrm{pm}$ & 182 & 0.7 & Rating ourve \\
\hline 160 & Seranac River & Sararac, N.Y. & Clinton & $1930-1936$ & $\Delta p r \cdot 17,1933$ & 5,780 & 521 & Jaly $9,2 \mathrm{am}$ & 936 & 1.8 & Rating curve \\
\hline 161 & Ausable River (W. $\mathrm{Br}$. ) & Near Yewman, N.Y. & Essex & $\begin{array}{l}1916-1917 \\
1919-1935\end{array}$ & Oct.6,1932 & 6,200 & 116 & July $9,6 \mathrm{sm}$ & 650 & 5.6 & Rating curve \\
\hline 162 & Ausable River & Hear Ausable Foriks, N.Y. & clint on & $1910-1935$ & $\operatorname{Max} \cdot 27,1913$ & 25,000 & 448 & July $9,7 \mathrm{am}$ & 3,440 & 7.7 & Rating curve \\
\hline 163 & Black Brook & Black Brook, X.Y. & Clinton & $1924-1935$ & Apr.25, 1926 & 720 & 49.4 & July $10,7: 30 \mathrm{~mm}$ & $\mathbf{8} 82$ & 1.7 & Bating ourve \\
\hline 164 & Ausable River (E. Br.) & Ausable Forks, N.Y. & Essex & $1924-1935$ & oct.1,1924 & 11,000 & 198 & July $9,6 \mathrm{am}$ & 2,980 & 15 & Rating ourve \\
\hline 165 & Borquet ziver & T111 sboro, M.Y. & Fasex & $1923-1935$ & oct.1,1924 & 11,800 & 275 & July $9,8 \mathrm{pm}$ & 1,790 & 6.5 & Rating ourve \\
\hline 266 & Iake Gecrge & Rogers Rook, N.Y. & Essex & $1913-1935$ & Apr.18,1922 & $\mathrm{mb} .07$ & & July $12-13$ & $m 4.55$ & & \\
\hline 167 & Poultney River & Below Falr Haven, $\nabla t$. & Eutland & $1928-1935$ & Nov.20,1932 & 3,870 & 187 & July $8,12 x$ & 3,030 & 16 & Bating curve \\
\hline
\end{tabular}

a Materially affected by storage or diversion.

$m$ Gage height in feet.

$t$ Does not include flow through lock.

Record furnished by Blaok River Regulating Distriat, Watertown, W. Y.

$s$ Reccrd furnished by New York State Department of Publio Works. 
The maximum intensity of discharge (presumably a momentary peak) as determined by measurements in the fleld, shom on figure 22 and plate 24, was 2,520 second-feet per square mile, from 2.91 square miles of the Glen Creek drainage basin near Townsend, N. Y., corresponding to a run-off rate of 3.90 inches per hour over the drainage basin. The runoff from 2.34 square miles of the Softrater Creek drainage basin near cold Springs, N. Y., was 2,030 second-feet per square mile, or at the rate of 3.15 inches per hour over the drainage basin. From the indications of washout damage and other evidence it seems probable that there were numerous small streams whose intensities of discharge were equal to those thus determined, if not greater. Unfortunately, suitable locations for determinations of discharge were not found on these small streams. 0ther determinations of noteworthy intensities are given in the table.

\section{Storage reservoirs}

There are few storage reservolrs within the area of the most Intense mun-off. In general, at the beginning of the storm very little capacity was available for flood storage, with the result that most of the reservoirs quickly filled; but, though not exerting their maximum possible effect, they modifled the flows considerably. On figure 21 it is shown that Gilboa Reservoir, on Schoharie Creek, absorbed practically all the flood flow and reduced the flow in the creek below the reservolr to a small portion of what it might have been. The dams at several small reservoirs and lakes in the central part of the State failed, and the value of these bodies of water as regulators of stream flok was destroyed or greatly diminished.

\section{DAMAGE}

No attempt has been made here to summarize the property losses and damages caused by the flood, as it is understood that such information is being obtained by the Flood Control Survey, Corps of Engineers, U. S. Army, and will be available in 1 ts report.

Farm lands suffered generally from gullying, from being burled under stones and gravel, and from inundation. On plate 30 is shown the character of the damage wrought by the small streams that washed tons of stones and gravel onto the farm lands. 


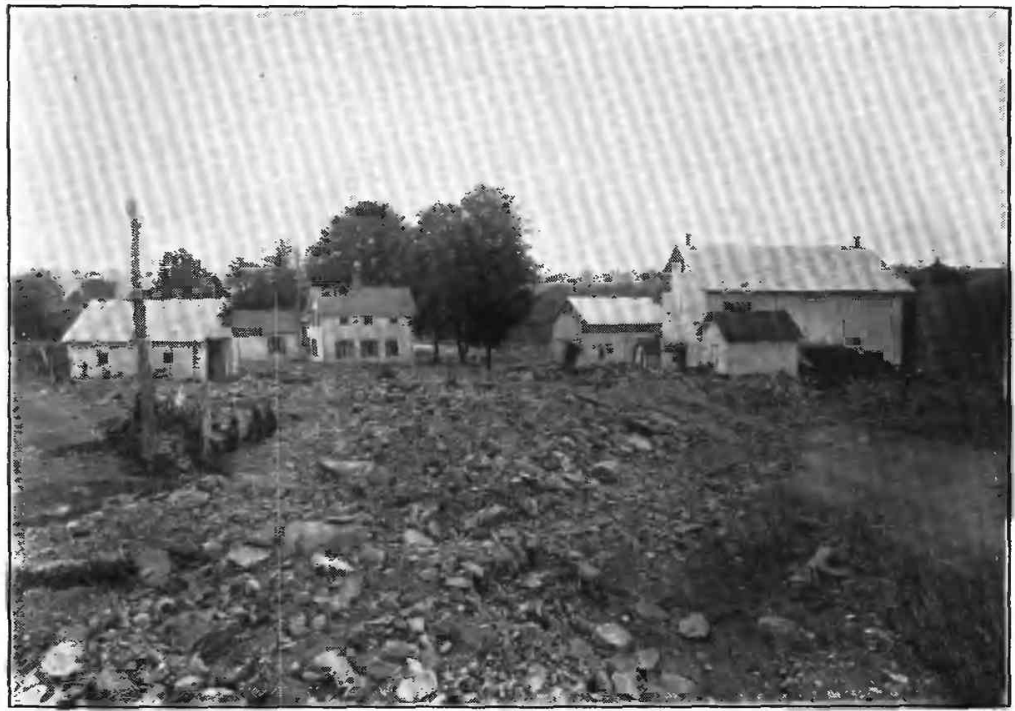

A. CHARLES BECKWITH FARM, SOUTH OF OXFORD, N. Y., SHOWING TYPICAL DAMAGE BY STONES AND GRAVEL TRANSPORTED BY SMALL STREAMS.

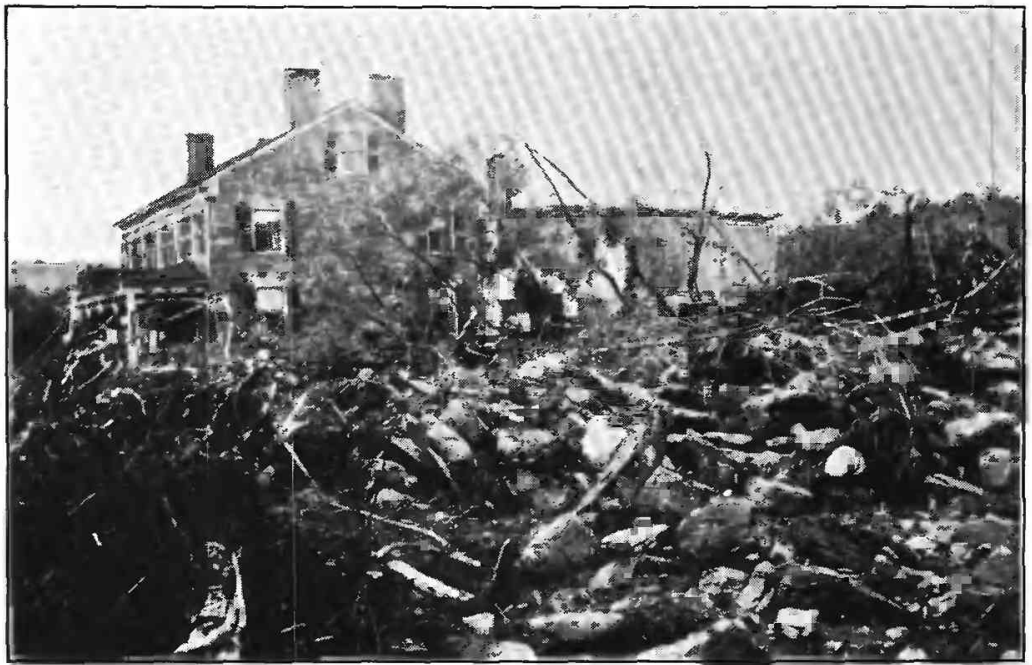

13. STONE HOUSE FARM, NEAR NORWICH, N. Y., SHOWING TYPICAL DEBRIS CARRIED BY SMALL STREAMS. 


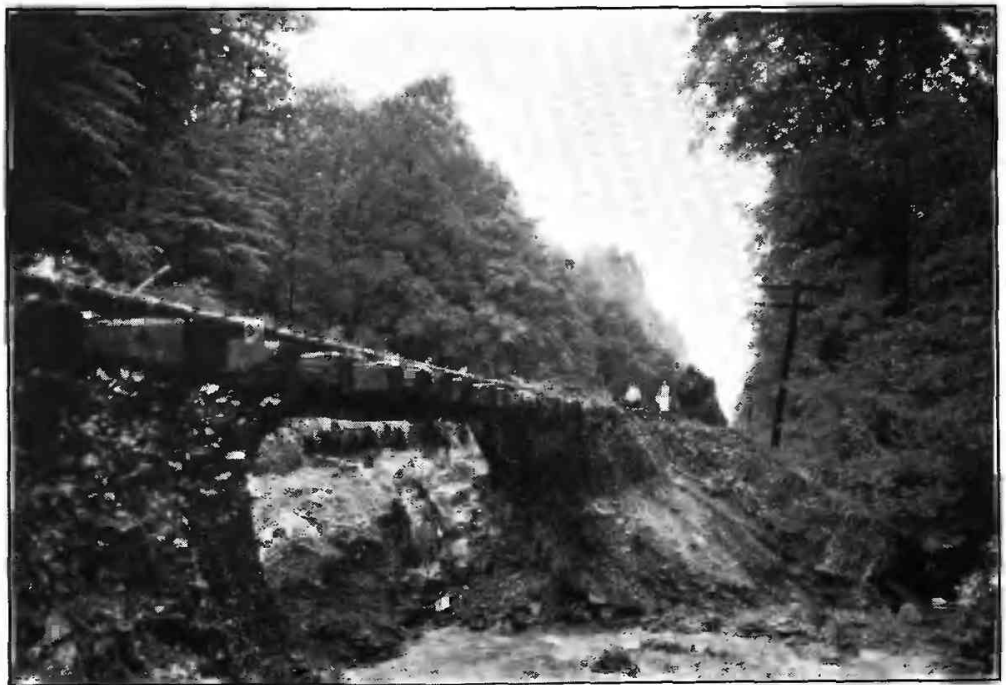

A. WASHOUT OF ROADBED, LEHIGH VALLEY RAILROAD.

The wreck of a passenger train was narrowly averted at this point.

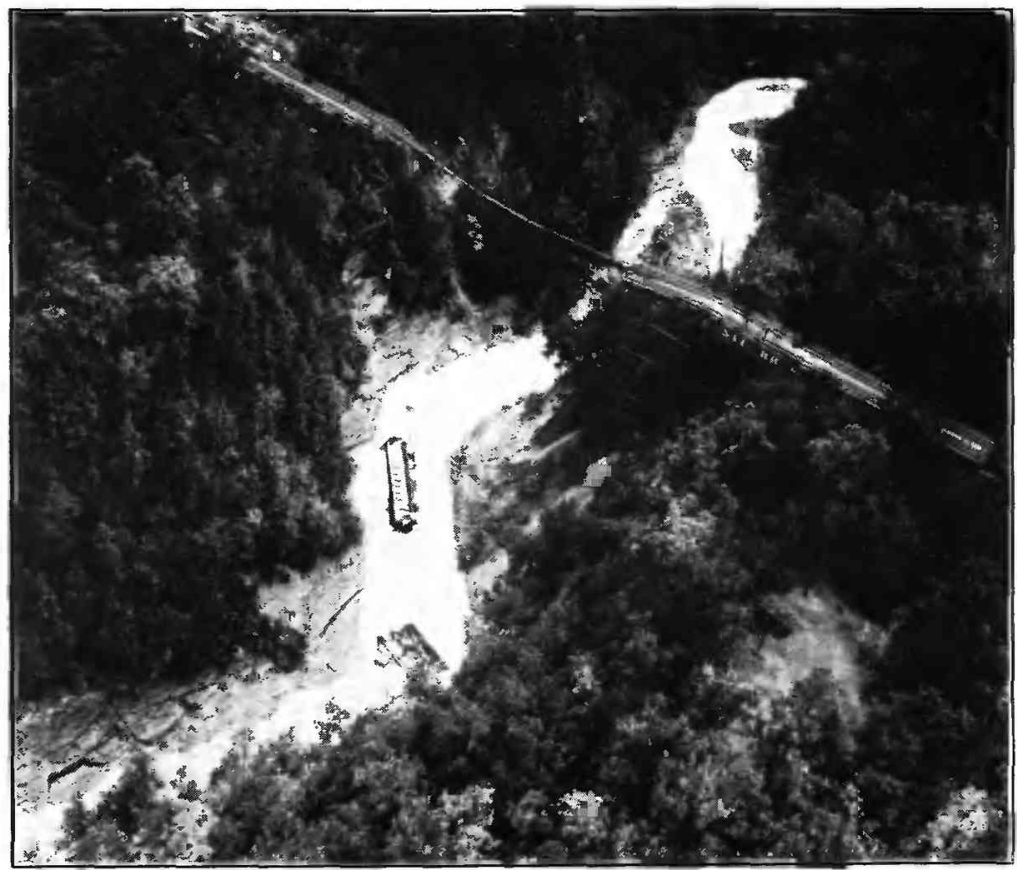

B. NEW YORK CENTRAL RAILROAD AT WATKINS GLEN, N. Y., SHOWING HIGH BPIDGE OVFR GLEN CREEK DESTROYED DURING THE FLOOD.

Courtesy of International News Photos, Inc. 


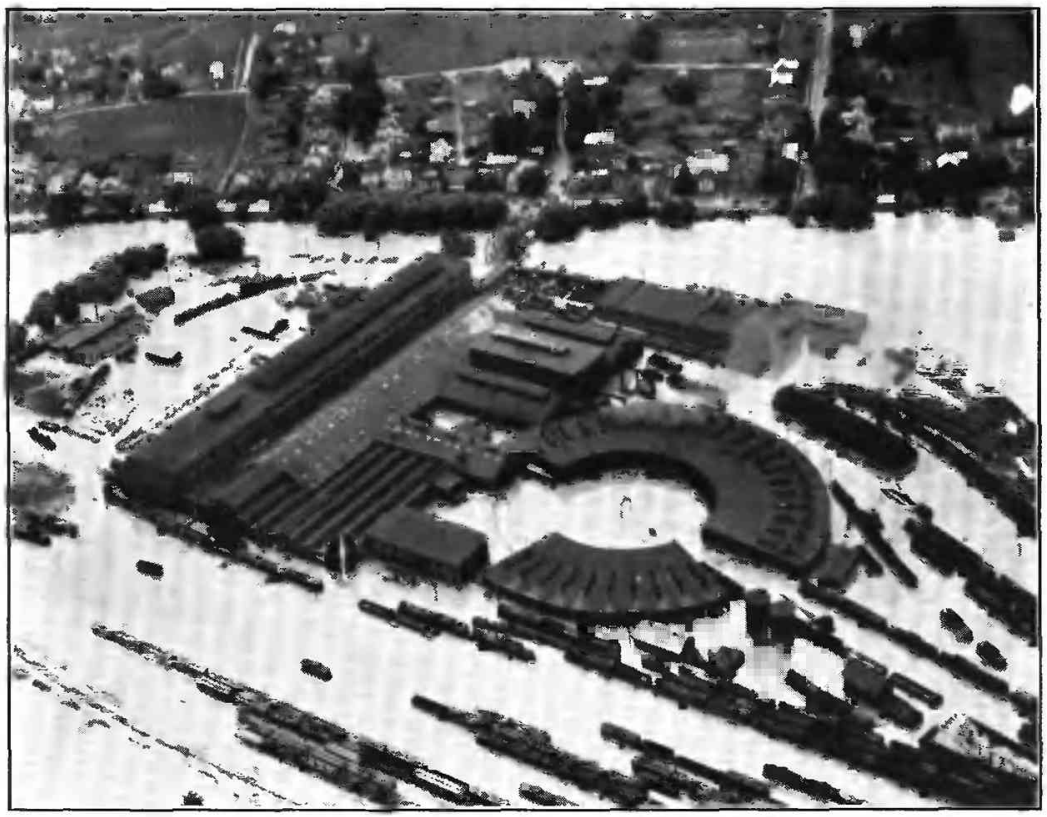

A. ERIE RAILROAD AT HORNELI., N. Y., SHOWING ROUNDHOUSE AND EQUIPMENT BURIED UNDER FLOOD WATERS

Courtesy of the Gannett Newspapers.

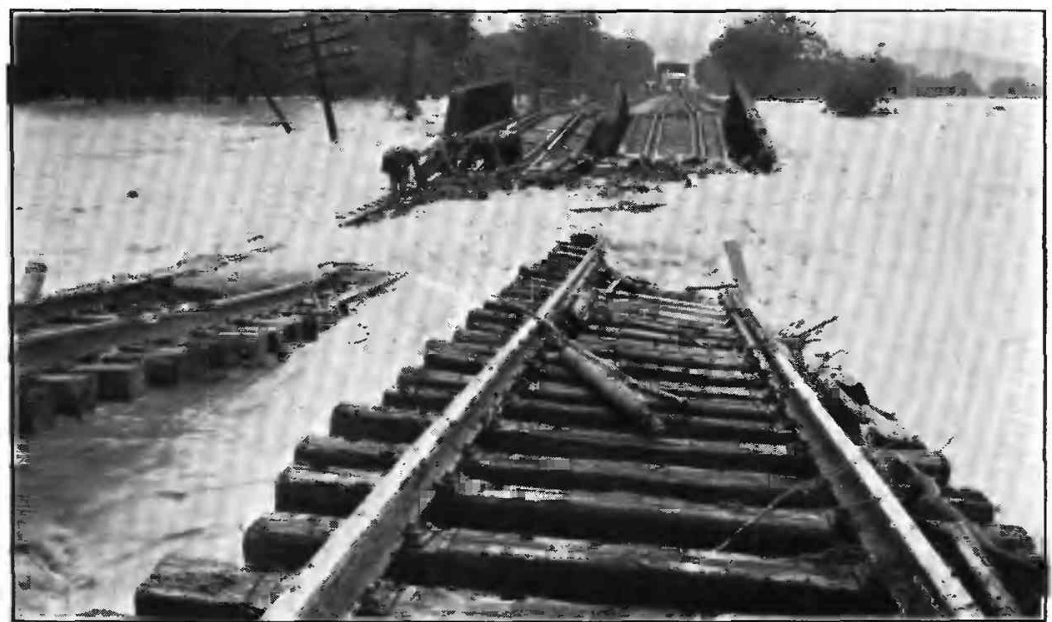

B. LACKAWANNA RAILROAD NEAR BATH, N. Y., SHOW ING TYPICAL FLOOD CONDITIONS 


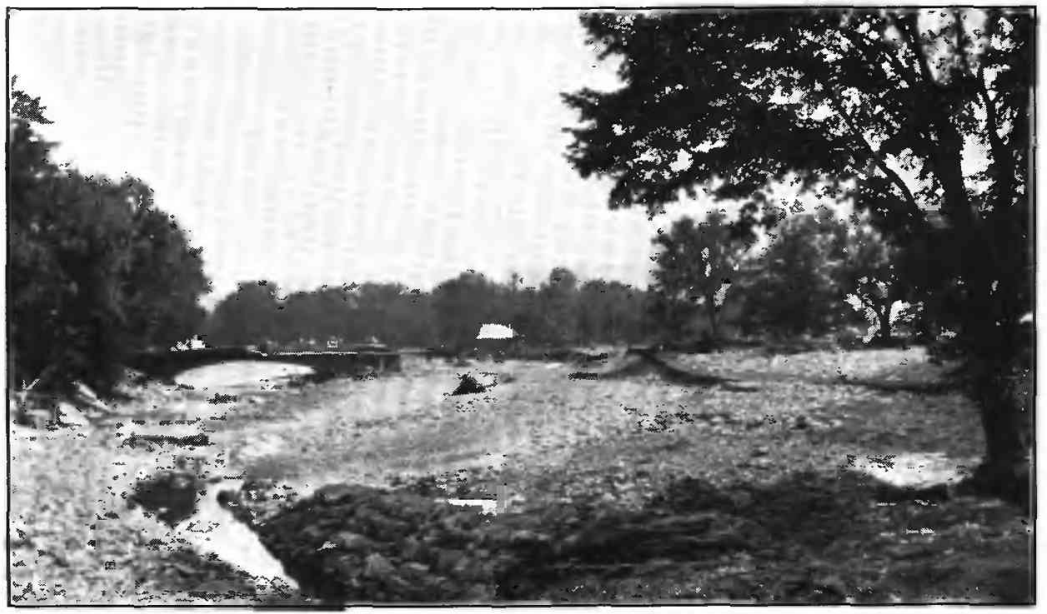

A. TAUGHANNOCK FALLS STATE PARK, N. Y., SHOWING DESTRUCTION OF ROAD DUE TO INADEQUACY OF BRIDGE TO CARRY FLOOD WATERS.

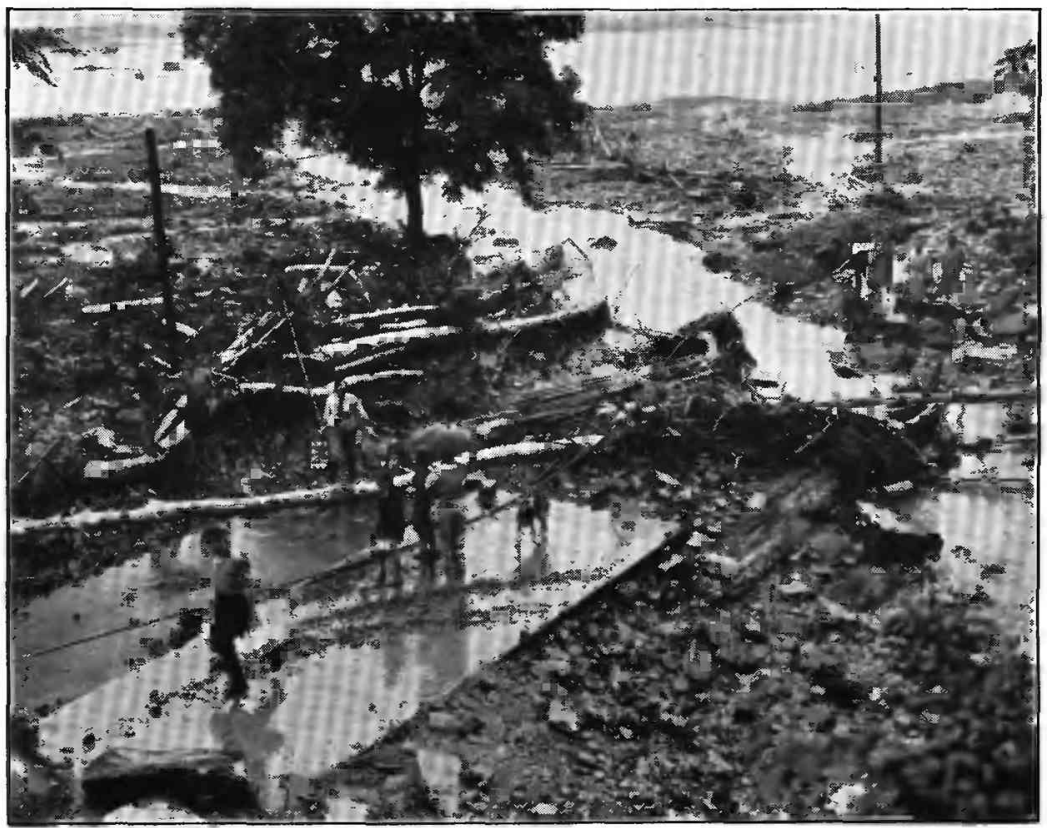

B. DESTRUCTION WROUGHT BY FLOOD ALONG TAUGHANNOCK BOULEVARD, ITHACA, N. Y.

This scene was typical of many others. 


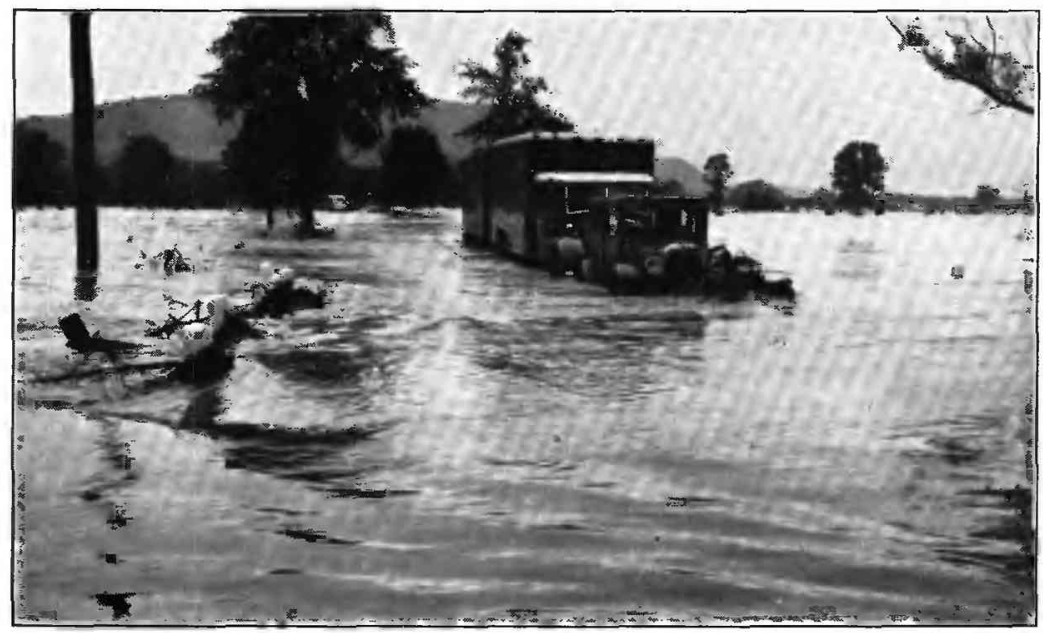

A. CARS AND TRUCKS MAROONED AND ABANDONED ON FLUODED HIGHWAY, KANONA, N. Y.

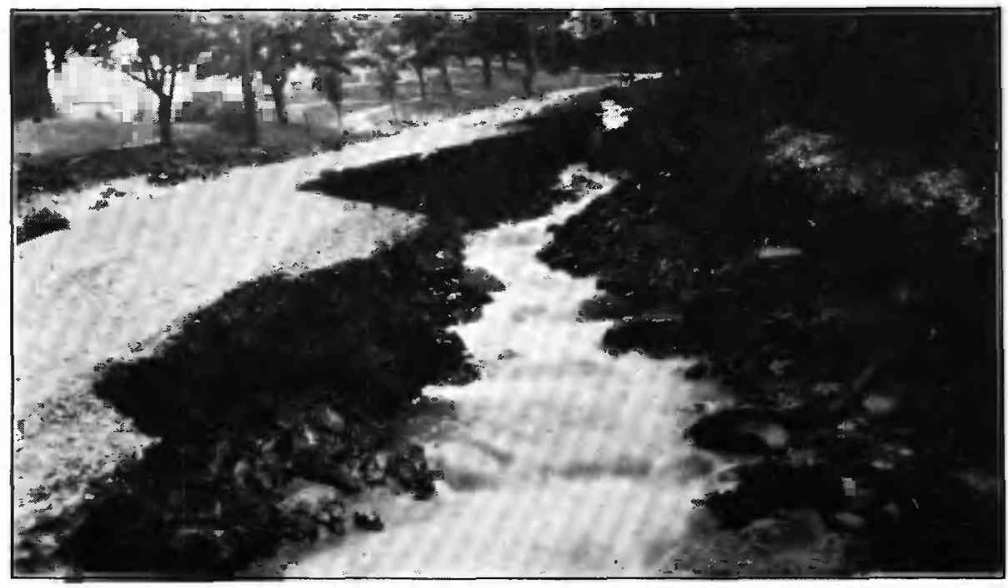

B. ROAD DFSTROYED BY GULLYING, NORWICH, N. Y. 


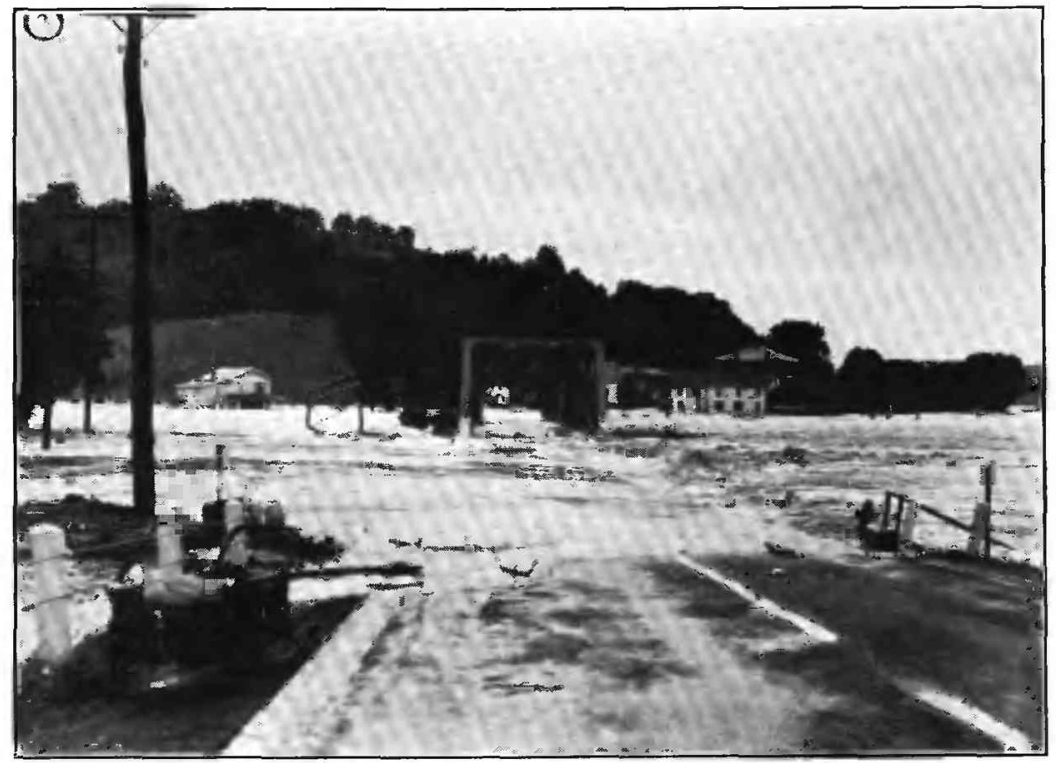

A. CHENANGO FORKS, N. Y., AT JUNCTION OF TIOUGHNIOGA AND CHENANGO RIVERS, SHOWING INADEQUACY OF BRIDGE OVER TIOUGHNIOGA RIVER TO CARRY FLOOD WATERS.

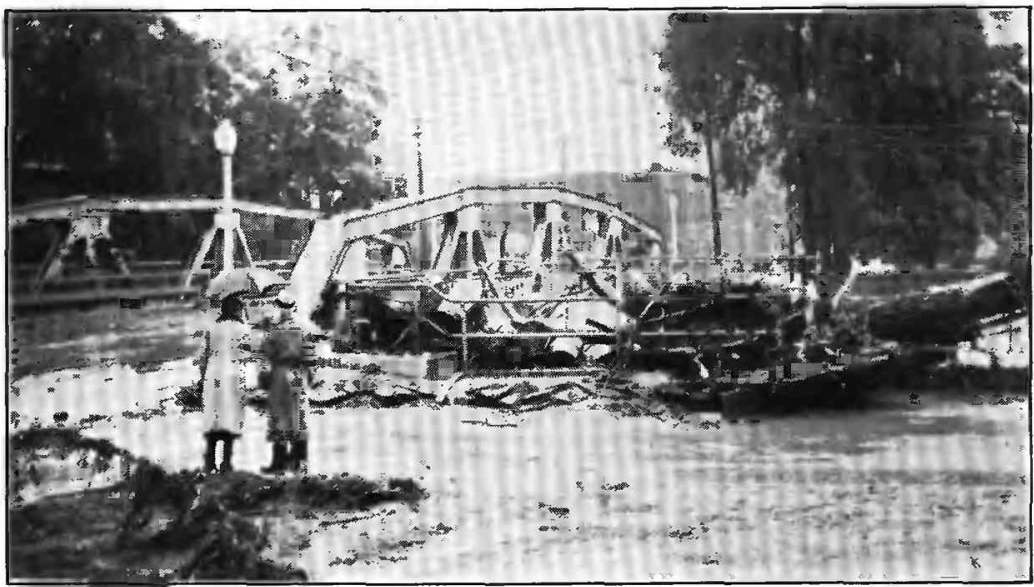

B. INADEQUACY OF SENECA STREET BRIDGE OVER CANACADEA CREEK, HORNEI.L, N. Y., TO CARRY FLOOD DEBRIS. 


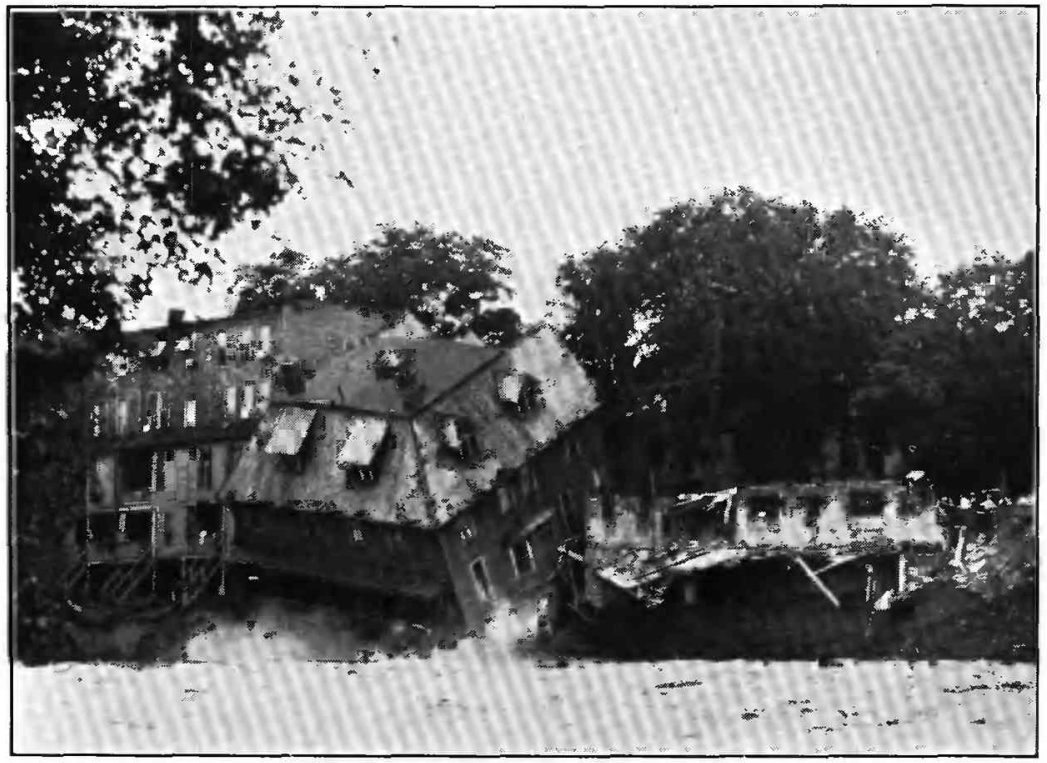

A. O'DAY HOUSE ON FRONT STREET, BINGHAMTON, N. Y., TOPPIING INTO THE FLOOD WATERS OF CHENANGO RIVER.

Courtesy of the Binghamton Press.

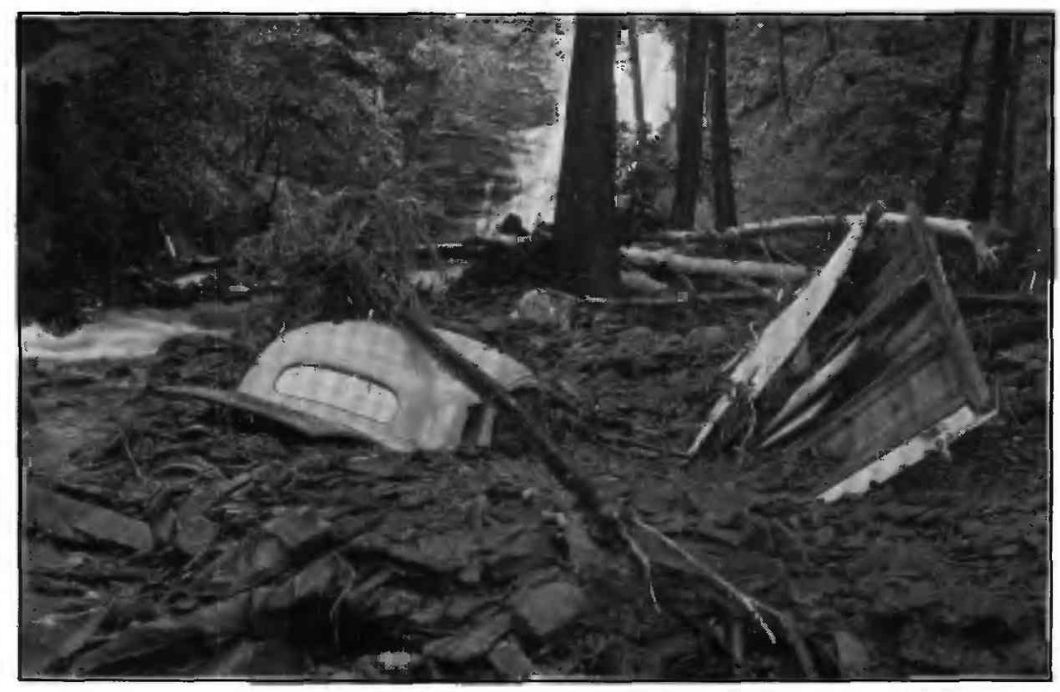

B. TYPICAL SIGHT WHEREVER THE FLOOD STRUCK. 


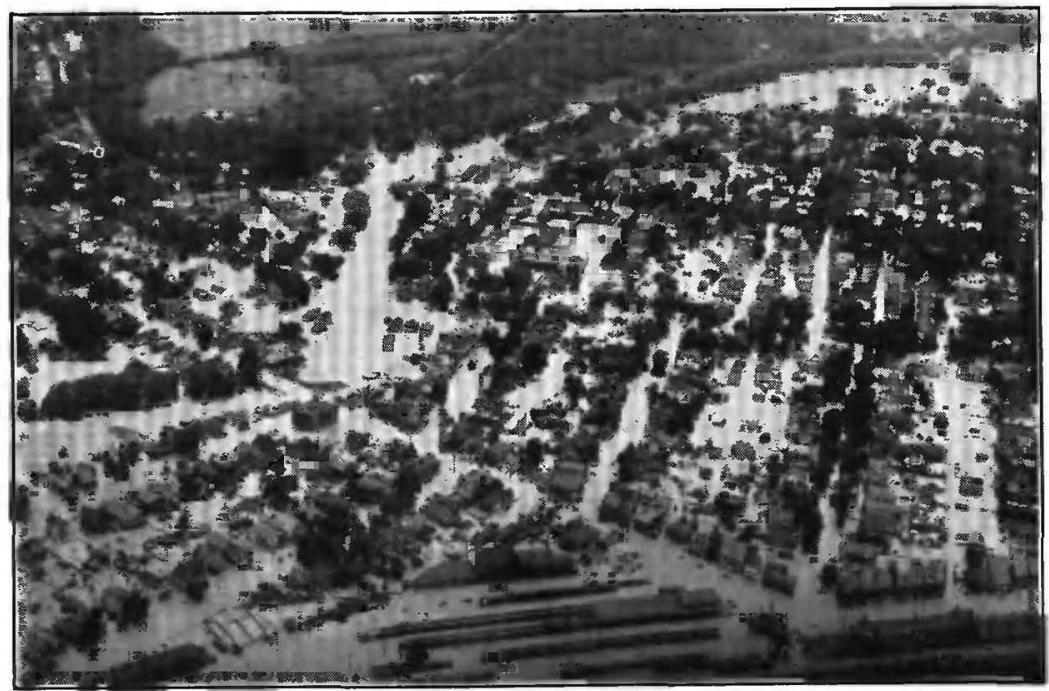

A. INUNDATION OF HOMES AND BUILDINGS, HORNELL, N. Y. Courtesy of the Gannett Newspapers.

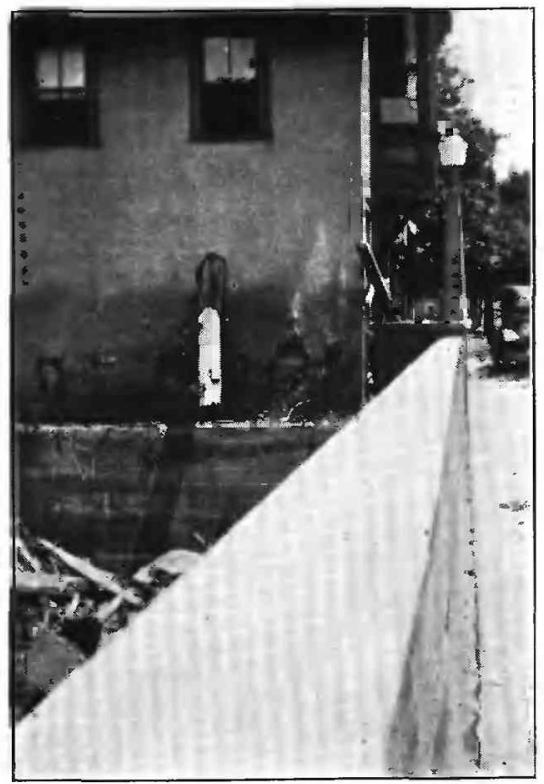

B. TELEPHONE POLE DRIYEN THROUGH SIDE WALL AND CEILING INTO THE SECOND FLOOR OF A HOME ON RIVER STREET, HORNELL, N. Y. 


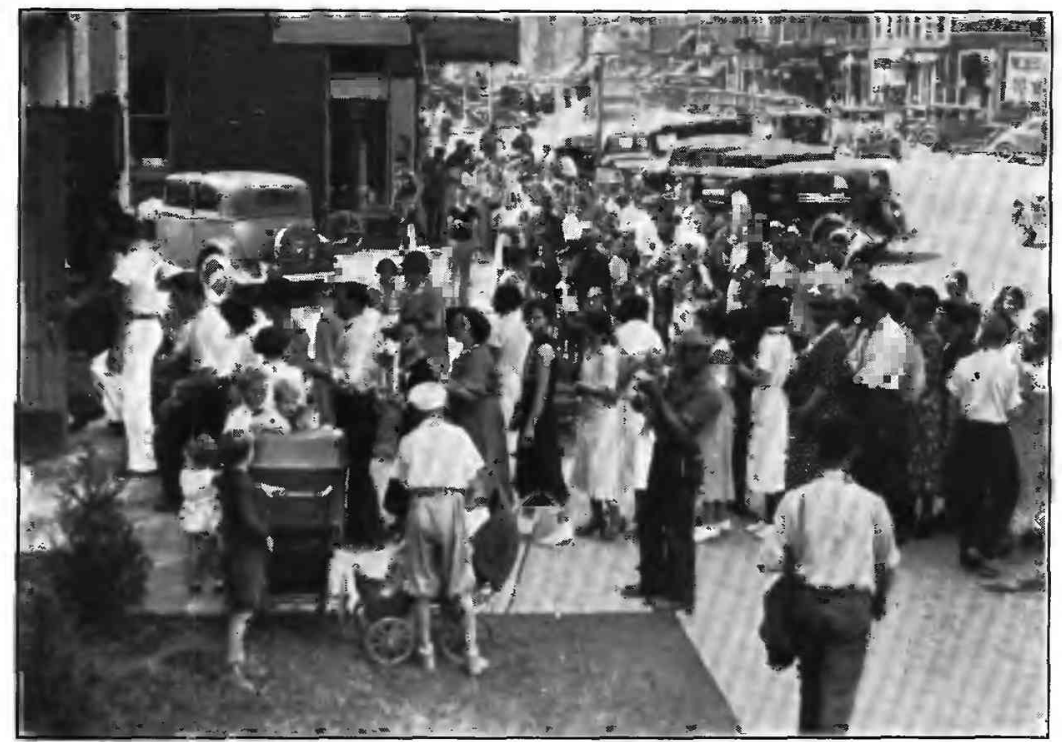

A. INOCULATION OF RESIDENTS AGAINST TYPHOID FEVER, HORNELL, N. Y. Courtesy of the Gannett Newspapers.

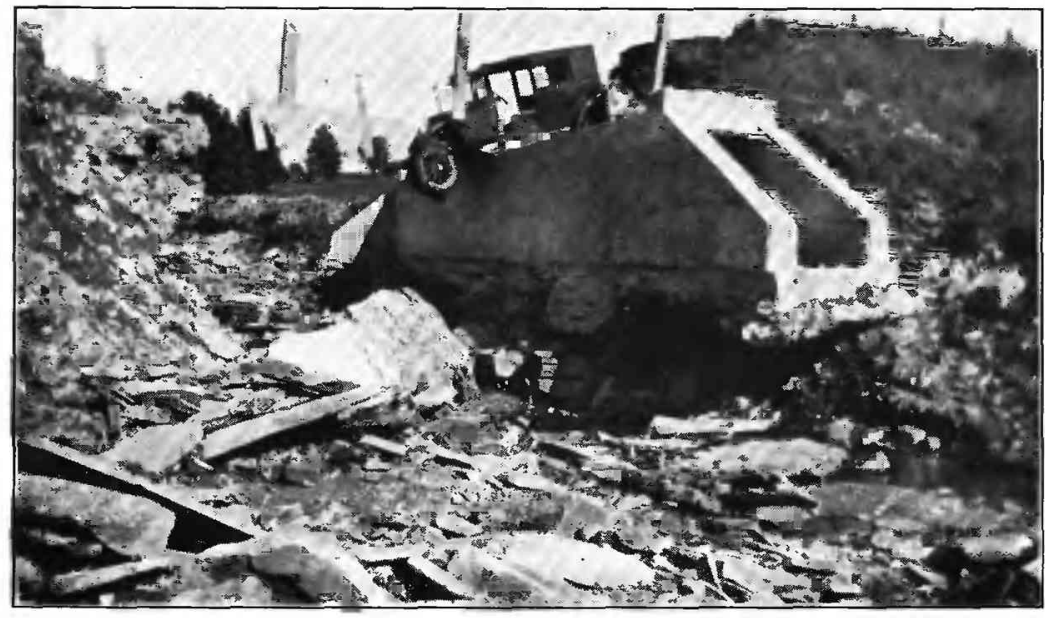

B. HAZARDOUS SITUATION FROM WHICH THREE PEOPLE PROVIDENTIALLY ESCAPED, SMITHVILLE FLATS, N. Y. 
Rallroad operations were suspended by the destruction of roadbeds and bridges and inundation of property and equipment. Plates 31 and 32 show the type of damage to the rallroads.

Miles of highways were rendered impassable by the destruction of the parements, bridges, and culverts and by the inadequacy of the structures to pass the flood waters. Plates 33 to 35 show some of the various types of damages to the highways.

Bulldings, automoblles, and private property of many kinds were destroyed, wrecked, buried, and inundated to the great loss of the owners. Plates 36 and 37 show some of the damages to private property.

A menace to health and Iffe was created by the flood. Water supplies were contaminated and destroyed. People were caught and swept away by the flood waters. Plate 38 shows one of the steps taken to safeguard health by inoculation against typhold fever and a hazardous situation from which three people providentially escaped with their lives.

\section{STORMS AND FLOODS IN THE SUSQUEHANNA RIVER BASIN}

IN THE VICINITY OF BINGHAMTON, N. Y.

Considerable information regarding historic and recent floods

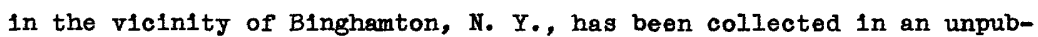
lished article, "Floods in the Binghamton district of the Susquehanna River watershed", by Thomas E. Reed, meteorologlst, and H. K. Gold, observer, United States Weather Bureau, Binghamton. The followlng notes on the storms and floods in this vicinity have been taken from thelr article:

Prior to about 1901 no systematic records were kept of the flood helghts along the rivers, and the information of storms and floods has necessarily been derived largely from newspaper accounts of the events. The following quotations are extracts from current newspaper accounts:

August, 1794. "Pumpkin freshet. So called because 1t swept through tne fields of ripening grain and over the farm lands, mining crops and carrying down hundreds of pumpkins. A famine threatened."

May 1833. "The late flood. Uncommonly destructive throughout the state." In the Chenango Valley "the smaller bridges generally gone, the banks of the streams cut up and torn away to a surprising extent, and the roads otherwise much injured. We have heard of no further loss of $11 \mathrm{fe}$. $* * *$ on the Chenango, several cattle were drowned. $* * * *$ On the Susquehann the fields of grain on the flats were much injured." Much damage was also done in Tloga County and to the Chemung Canal.

$566350-36-3$ 
May 23, 1840. "A most violent storm of rain" lasted but an hour and did considerable damage in Windsor. "Not a bridge is left between Wood's ( 5 miles from this place) and the Susquehanna at Windsor V111age."

February 3, 1842. "The freshet. Immense quantities of rain fell, and both the Chenango and Susquehama Rivers rose higher than ever know befor $\theta$. *** From every direction ve recelve accounts of the ravages of the freshet. Never, within memory of that distinguished personage, 'the oldest inhabitant', have the streams risen to such an appalling degre日,"

March 14 (?), 1846. "Extraordinary freshet. The water here has seldom if ever been higher. It never came upon us so suddenly." Several days of "mild and serene" weather followed by "a heavy rain" of "12 or 14 hours" on the snow "still very deep on our adjacent hills" caused this "extremely disastrous" flood. "A sudden and most providential change in the weather" checked the flood, and "had the weather continued mild the loss mast have been incalculably great." The damages were heavy in both the Chenango River and Susquehanna River valleys.

February 9, 1857. "The February thaw - great freshet in the Susquehanna and Chenango Rivers." Three days of warm weather "carried off the snow with extraordinary rapidity, sending the ice out of the rivers in 2:40 time" and raising the rivers "as high as they have been in several years." Damage, as reported, was chiefly to bridges on both the Chenango and Susquehanna Rivers.

March 17, 1865. Deop snows on the headwaters, "rapidiy melting away in the face of the sun and south wind" and a severe rain, caused this great flood, "estimated as being from 4 to 8 feet higher than it had ever been known to be by white men. The Chenango River was considerably the highest, and its current was by far the most strong and raging." Houses in Binghamton were "in the water up to the first and second stories."

March 12, 1879. "The rivers are rising under the influence of melting snow, and the peaceful, slumbering ice is evidently preparing to gorge itself on bridges and mill property. $n$ Ice jams caused damage at Whitney Point, on the Tloughnioga River, and at Blnghamton, on the Susquehanna River.

December 15, 1901. "Terrible rains caused flood. Binghamton was completely isolated from the outside world from saturday night until early this morning (Monday) by the worst flood since 1865." The Chenango River at the Court Street Bridge reached a maximum observed stage of 20.4

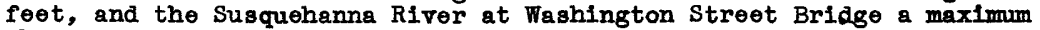
observed stage of 14.9 feet. Great damage was done by inundation and washouts on the ralilroads and roads.

March 2, 1902. There was undoubtedly a heavy cover of snon over the upper portions of the drainage basin, which rapidiy melted during the 5 or 6 days of unusually warm weather and light rains that preceded the flood. The Chenango River at Court Street Bridge rose to an observed stage of 23.1 feet. The Susquehanna River at Washington Street rose to an observed stage of 19.7 feet. Accounts of the flood state that the Susquehanna River reached a point 8 inches below the mark of the flood of 1865. "One of the most reliable marks of the flood of 1865 is afforded by two nails driven in the cormer of the building at the corner of South and Carroll Streets, driven in the building in question at time of very highest, March 17, 1865." Much damage resulted from inundation and the destruction of highway and rallroad structures.

1901-1935. At the Washington Street Bridge on the Susquehanna River at Binghamton, the United States Weather Bureau has daily observed the stage of the river since 1901. At the Court Street Bridge on the Chenango River the United States Geological Survey daily observed the stage of the river from 1901 to 1911, and after 1911 the United States Weather Bureau observed the stage occasionaliy at times of threatening floods and in 1933 resumed daliy observations. The following table shows the date of occurrence and the maximum observed stage each year on the Susquehanna and Chenango Rivers: 
Maximum observed river stages, in feet, at Binghamton, N. $Y$.

\begin{tabular}{|c|c|c|c|c|}
\hline \multirow{2}{*}{ Year } & \multicolumn{2}{|c|}{ Sugquehanna RIver } & \multicolumn{2}{|c|}{ Chenango Rlver } \\
\hline & Date & Feet & Date & Feet \\
\hline $\begin{array}{l}1901 * \\
1902 \\
1903 \\
1904 \\
1905 \\
1906 \\
1907 \\
1908 \\
1909 \\
1910 \\
1911 \\
1912 \\
1913 \\
1914 \\
1915 \\
1916 \\
1917 \\
1918 \\
1919 \\
1920 \\
1921 \\
1922 \\
1923 \\
1924 \\
1925 \\
1926 \\
1927 \\
1921 \\
1928 \\
1929 \\
1930 \\
1931 \\
1932 \\
1933 \\
1934 \\
1935 \\
1935\end{array}$ & $\begin{array}{lr}\text { Dec. } 15 \\
\text { Mar. } & 2 \\
\text { Oct. } 11 \\
\text { Mar. } 27 \\
\text { Mar. } 26 \\
\text { Mar. } 29 \\
\text { Dec. } 11 \\
\text { Feb. } 16 \\
\text { Feb. } 21 \\
\text { Mar. } 2 \\
\text { Mar. } 28 \\
\text { Apr. } 3 \\
\text { Mar. } 28 \\
\text { Mar. } 29 \\
\text { July } 9 \\
\text { Apr. } 2 \\
\text { Mar. } 28 \\
\text { Mar. } 11 \\
\text { May } 11 \\
\text { Mar. } 28 \\
\text { Nov. } 29 \\
\text { Mar. } 8 \\
\text { Mar. } 24 \\
\text { Oct. } 1 \\
\text { Feb. } 12 \\
\text { Mor. } 17 \\
\text { Oct. } 19 \\
\text { Mar. } 27 \\
\text { Mar. } 16 \\
\text { Jan. } 26 \\
\text { Mar. } 27 \\
\text { Oct. } 7 \\
\text { Aug. } 25 \\
\text { Mar. } 5 \\
\text { Jan. } 10 \\
\text { July } 8\end{array}$ & $\begin{array}{r}14.9 \\
19.7 \\
17.6 \\
17.8 \\
14.9 \\
9.9 \\
12.8 \\
14.0 \\
12.4 \\
17.7 \\
14.3 \\
14.5 \\
18.6 \\
18.5 \\
15.2 \\
16.5 \\
13.9 \\
12.0 \\
7.7 \\
14.6 \\
14.3 \\
12.8 \\
13.5 \\
17.2 \\
17.2 \\
14.4 \\
16.6 \\
11.5 \\
17.7 \\
9.5 \\
11.4 \\
12.2 \\
10.8 \\
17.7 \\
16.8 \\
17.7\end{array}$ & $\begin{array}{lr}\text { Dec. } & 15 \\
\text { Mar. } 2 \\
\text { Oct. } 11 \\
\text { Mar. } 27 \\
\text { Mar. } 26 \\
\text { Mar. } 28 \\
\text { Jan. } 5 \\
\text { Feb. } 16 \\
\text { Feb. } 21 \\
\text { Mar. } 2 \\
\text { Mar. } 28 \\
\text { Mar. } 28 \\
\text { Mar. } 29 \\
\\
\text { Apr. } 2\end{array}$ & $\begin{array}{l}20.4 \\
23.7 \\
20.3 \\
20.8 \\
18.7 \\
13.8 \\
13.8 \\
17.0 \\
15.7 \\
21.4 \\
18.1 \\
22.3 \\
22.3 \\
20.1\end{array}$ \\
\hline
\end{tabular}

*Record starts in August 1901.

The flood of July 8, 1935, w111 long be remembered as the most sudden and most destructive flood that has ever occurred in the upper Susquehanna River Basin, particularly throughout the Chenango and Tloughnloga Valleys. Unprecedented rains that developed from severe and contimuous thundershowers, popularly called "cloudbursts", occurred, particularly during the night of July 7-8, throughout Cortland and Chenango Counties, comprising the drainage areas of the upper basins, and to a lesser degree in northerm Broome, Otsego, and Delaware Counties. While Cortland recorded a fall of 6.12 inches in 12 hours, from 5:00 p.m. July 7 to 5:00 a.m. July 8, there was but 0.10 inch recorded at the Binghomton station, only 40 miles distant. The greatest previous record 
for a 24-hour period at Cortland was 4.87 inches. The greatest record for a 24-hour period at Binghamton was 4.55 inches, on September 30, 1924. The small streams and rivers were soon out of their banks, and a wall-like crest of water moved down the basins, converging at Binghamton, where the Susquehanna and Chenango Valleys meet. From a low stage of 1.3 feet at Binghamton the Chenango RIver rose above flood stage on the morning of July 8 within 4 hours and reached 1ts crest of 24.80 feet 6 hours later, at 3:00 p.m. of that day. A number of lives were lost in the upper besins during the early morning hours of July 8 . Hundreds of families were driven from their homes, particularly in the first ward of the clty of Binghamton, which was bady flooded when the rising waters overflowed the west bank, and in that portion of Front Street north of the Ferry Street Bridge, which adjoins the first ward. A house at 208 Oak Street, in the first ward, bearing a crest mark of the great flood In that section of the city on March 17, 1865, shows that this height is 9 inches lower than the high-water mark of July 8, 1935.

The Susquehama River at Binghamton did not rise as high as on previous occasions, the crest of 17.72 feet being recorded about 3:00 p.m. July 8 . Both rivers contimued in flood for about 50 hours.

Property damage of all kinds throughout the basins comprised In the district mounted uprard to $\$ 8,000,000$.

The record of former floods indicates the marked prevalence of winter and spring floods and the very rare occurrence of major sumer floods in the Susquehanna River Basin in the vicinity of Binghamton. It is interesting to note that prior to July 1935 the highest observed stage of the Susquehanna River at Binghamton for each calendar month since the beginning of the record in 1901 has been as follows:

$\begin{array}{llllll} & & \text { Feet } & & & \text { Fe日t } \\ \text { January } & 1935 & 16.8 & \text { July } & 1915 & 15.2 \\ \text { February } & 1925 & 17.2 & \text { August } & 1903 & 11.0 \\ \text { March } & 1902 & 19.7 & \text { September } & 1924 & 15.3 \\ \text { Apr } 11 & 1916 & 16.5 & \text { October } & 1903 & 17.6 \\ \text { May } & 1927 & 12.0 & \text { November } & 1926 & 14.4 \\ \text { June } & 1922 & 10.3 & \text { December } & 1901 & 14.9\end{array}$




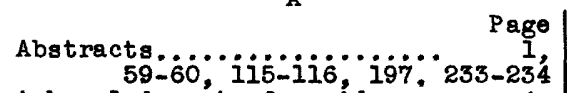
Acknowledgments for ald..... 4 , $61,117-113,220,234$

Alachua County, Fla., plezometric surface in ... 149-150 pressure heads and water levels in wells in.... 190 records of wells in......i65, 175 Alachua formation, age, thickness, and character of ..............

Alexander spring, Fia.. discherge of ......... 155

Allegheny RIver, N. '̈.., flood discharge of....

Alum Bluff group, formations

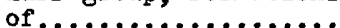

Anacacho ilmestone, age; thickness, and waterbearing properties of.

Anastasia formation, age, thickness, cháracter, and water-bearing proporties of .............

Artesian flow, areas of, in Flor1da.......132-133, pl. 10

increase of, with Increased depth. ...... 134-135

Artesian head, decline of, In Kleberg County,

Tex................209-212

definition and mes surement

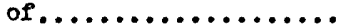

depression in, near Kingsville, Tex.......

fluctuations of ...........135-145

fluctuations of, due to atmospheric pressure..139-140 due to draft from wells. 142, 144

due to ocean tides...... 141 due to rainfall......... 136-138, 142,143

due to river otages.....141-142 influence of drainage wells on ...........142, 143

increase of, with increased depth.......134-135 permanent 108 of ........ 145 Artesian pressure, fiuctuat1ons in......32-100, 209-212 gradientg of ..............100-102 measurement of, in Kleberg County, Tex........... 200

Artesian water, generai conditions of, in Florida.............131-132

Artesian wells, concentration of, in Florida irrigation districts.. 158 general features of ......157-160 specific capacity of...... 159 subsurface leakage of ...... 160-161 waste of water from, Texas law conceming.......218-219

See also Wells.
Atmospheric pressure, fluc-.

Page tuations in artesian head due to...........139-140

Ausable River, N. Y., flood discharge of ......... 263

East Branch of, flood discharge of ........ 263

West Branch of, fiood discherge of ....... 263

Austin chalk, age of........ 67 thickness and water-bearing properties of...67, $69-70$

\section{B}

Baker County, Fla., area of artesian flow in...... 133 piezometric surface in....149-150 records of wells in...... 165, 175 subsurface leakage of wells in........... 160

Balcores escarpment, features of ......... 71

Bath, N. Y., typicai fiood conditions on Lackawanna Railroad near... pl. 32

Battenkill, N. Y., flood discharges of ....... 256

Beaumont clay, age of....... 200 character and water-bearing properties of ...200, 201

wells obtaining water from. 220 Beaver Kill, N. Y., flood discharge of........ 258

Beaver River, N. Y., flood discharges of......... 262

Bennett Creek, N, Y., fiood discharges of........

Beverly Lodges well, Tex., fluctuation of arteslan pressure in.93-94, 95-98

Bexar County, Tex., map of, showing geology and artesian conditions... pl. 5 Blg Creek, N. Y., flood discharge of ........ 260

Binghamton, N. Y., fiood conditions in...... 246 is. 23,

maximum river stages at...267, 268 storms and floods in Susquehanna River Basin near......... 265-268 Bird Brook, N. $Y .$, flood discharge of ......... 257

Black RIver, N. Y., flood discharges of.........

Blue Spring, Madison County, Fla., discharge of ...

Volusia County, Fla., discharge and temperature

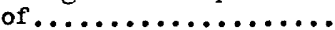
prings, Marion County, Fla., discharge of ... i55, 151 ,

Marion County, Fla., temperature of......... 155 view of.............. pl. 14 
Bone Valley gravel, age, thickness, and character of .........

Bouquet River, N. $\dot{Y}$., flood discharge of..........

Brackenridge Park, San Antonio, Tex., contribution of well water from, to swimming pool and river supply..... 88,90

pumping plant at, fluctuations in artegian pressure at. .......93,94-95

Bredford, N. Y., flood discharge of unnamed brook near...........

Bradford County, Fia., plezometric surface in..149, 150

records of wells in......165, 175

Brevard County, Fla., pressure heads' and water levels in wells

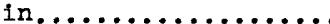

records of weils in... $165,175-176$

salt bed in well in.... 164

specific capacity of weils

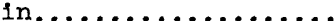

yield of artesian weil $\ddot{i n}$.

Bridges, T. W., Livingston, Penn, and, Groundwater resources of Kleberg County, Tex..197-232, pis. 17-2i

Broward County, Fla. records of weils in..166, 176

Brown, R. W., quoted........

Buda iimestone, age, thickness, and water-bearing properties of.....

Burdett, N. Y., flood discharge of unnamed creek near.............

By ram marl, occurrence of...

\section{C}

Caloosahatcheo marl, age, thickness, character, and water-bearing properties of.........

Camden County, N. C., outline of geology of.... physical properties of material from.........

surface features of....... Campbell Creek, N. Y., flood discharge of ..........

Canacadea. Creek, N. $\mathrm{Y}_{\text {.. }}$ flood discharges of...

Canada Creek, N. Y. See East Canada Creek; West Canada Creek.

Canaseraga Creek, N. Y., flood discharge of ....

Canlateo River, N. Y., fiood discharges of.........

Carrington Creek, $\mathrm{N}$. $\ddot{\mathrm{Y}}$. flood discharge of....

Carrizo sand, permeablilty

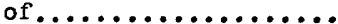

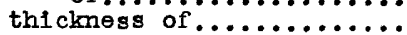
water-boaring properties of ..............667

$10-11$

260

260

Cascadilia Creok, N. Y. flood discharges of...

261

260
Catskil1 Creek, N. Y. flood discharge of.... Page

Cedar Rlver, N. Y., flood

discharge of........ 256

Channel sections, typical... 253,

Charlotte County, Fla., pls. 27, 28 record of well in....166, 177

Charlton formation, age, thickness, and charac-

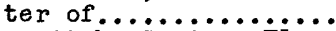

Chassahowitska Spring, Fla., discharge of ..........

Chateaugay River, $\dot{N} . \dot{Y}$., flood discharge of ....

Chaumont River, N. Y., flood discharge of ..........

Chemung River, N. Y... flood di s charges of ........259-260

Chenango Forks, N. $\dot{Y}_{\text {., flood }}$ damage at............. pl. 35

Chenango River, $\dot{N}_{.} \ddot{Y}_{.}$, fiood discharges of .........

at Binghamton, $N$. $Y$., maximum stages of.....

267

Cherry Valley Creek, N. $\mathrm{Y}_{\text {., }}$ flood discharge of....

Chipola formation. See Aium Bluff group.

Chloride, occurrence of, in weil waters in

Florida.......162-164, pl. 16

occurrence of, in well

waters in Kleberg

County, Tex.........215-216

Choctawhatchee formation, age, thickness, and character of........122, 130

citronelle formation, age, thickness, character, and water-bearing properties of.........

Citrus County, Fla., area of artesian flow in.....

plezometric surface in.... 152-153 pressure heads and water

levels in wells in.... 190

records of wells in....... 166, 176

Clay County, Fla, area of a rtesian flow in..... 133

artesian pressure in...... 161

plezometric surface in.... 149-150 pressure heads and water levels in wells in... records of wells in..166, I76-177 speciflc capacity of wells In................. 159

clear Brook, $\mathrm{N}_{\mathrm{Y}}$., flood discharge of..........

Coastal Plain, features of... 10-11,

Cohocton River, N. Y., flood discharges of ......... 66,198

Cold Spring Brook, $\dot{\mathrm{N}} \cdot \ddot{\mathrm{Y}}_{\text {., }}$ flood discharge of....

Collier County, Fla., pressure 'heads' and weter levels in wells

in............... 190

records of weils in....... i66, 176 Columbia County, Fla., pressure heads and water levels in wells

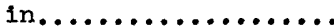

records of weils in........ i66, 177 
Comal County, Tex., map of part of, showing geology and artesian conditions........... pl. 5

Comanche Peak limestone, age, thickness, and water-bearing properties of............

Comanche series, occurrence, character and waterbearing properties of

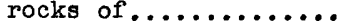

Cooke, C. W., and Mossom, Stuart, quoted........119-120

Crescent Beach, Fla., submarine spring near, temperature of........ yleld of artesian weij $i$ t.

retaceous rocks, deeply burled, mineralized

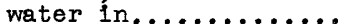

occurrence and character of .......67, 122

Croton Rlver, N. Y., fiood discharges of.........

Crystal Springs, Fla., discharge of...........

D

Dade County, Fla., piezometric surface in....

records of wells in..... i66, 154

Damage, amount of, caused by flood in New York July 1935.......233, 264-265

Dams, flow over, computation

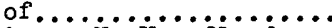

Deer Rlver, $\ddot{N}$. $\ddot{Y}$.. fiood discharge of ..........

254

Delaware River Basin, fiood discharges of streams

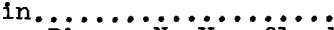

Delaware River, N. Y... flood discharge of.........

East Branch of, filood discharges of ........

West Branch of, flood discharge of .........

Del Rio clay, age, thickness, and water-bearing properties of.....

Depauvilie, N. Y., flood discharge of unnamed brook near...........

262 o County, Fia. records of weils in..167, 177

Diatoms, occurrence of, in Elizabeth City area,

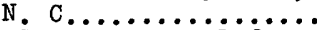

Dismal Swamp, general features of ............

water-bearing beds in, thickness of .........

Drops, flow through, computation of .............

Dudley Creek, N. $Y_{.}$, flood. discharge of ...........

Duval County, Fla., area of artesian flow in......

artesian pressure in Hawthorn formation in....

258

piezometric surface in .... 150-151 pressure heads and water levels in wells in... 190-191 records of wells in..167, 177-178
E

Page

Eagle Ford clay, age, thickness, and water-bearing properties of.....

East Creek, N. Y., flood discharge of .........

East Canada Creek, N. Y. flood discharge of....

East Stony Creek, N. Y., flood discharge of....

Edwards limestone, age of... discharge of ground water from, by springs......

by welis.............. ground-water reservoir in, discharge from........ fluctuation in artesian pressure in.......... general features of ..... 72-74 movement of water in...100-101 recharge to........... $75-79$ safe yleld of ...........102-103 ground-water resources of, investigation of...... industrial water supplies from.............. 88, 90 map of outcrops of ....... pi. 5 public water supplies from............87-88, 90 quality of water from...... 104 thickness and water-bearing properties of..... 67, 69 waste of water from wells in............... 91-92

Edwards Piateau, general features of ......... 65-66 regimen of streams of.... 77-78 Elizabeth City, N. C, deep test weli at, log of..

deep test well at, pumpIng test on......... 23-25

location and population of 2 public water supply of, adequacy of ground water for............

present source of...... 4-10

problem of ........... 2-3

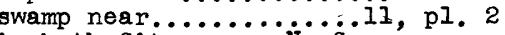

Elizabeth City area, N. C., climate of .......... 11-13

map of, showing groundwater conditions...... pl. 1

outline of water-bearing beds in.............

purpose of ground-water investigation in...... shallow-well fleld in, selection of site for. 49-50 strata encountered in test drilling in......... 13-21 streams in, analyses of waters from......... 57

typlcal well sweep in....̈2, pl. 3 water in storage in ...... 47 Eocene rocks, deeply burled, mineraízed water in.. 122 occurrence and character of ..........67, 122, 123

Erie Railroad, flood conditions on, at Hornell, N. Y.............. pl. 32

Esopus Creek, $\dot{N}_{.} \ddot{Y}_{.}$, fiood discharge of......... 


\section{F}

Fall Creek, N. Y., flood discharge of ..........

Falls, flow over, computa-

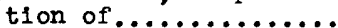

261

\section{Falmouth Spring, Fla... \\ Falmouth Spring, Fia.,}

Fannin Spring, Fla., discharge of ...........

Farm lands, damage to, by flood...........264, pl. 30

Fleld work....................... $3-4$ $61,117, \cdots 9 \ddot{9}-19 \dot{8}, \cdots 234,249-250$

Fish Creek, N. Y., flood discharge of ......... 262

Fishel, V. C., laboratory tests of material by..

Five Mile Creek, N. Y., flood discharge of ....

Flagler County, Fla., plezometric surface in..... 38,36

261

151

well $3 \mathrm{ln}$, flow of .... i $3 \dot{8}$, pl. 13

wells in, records of.....167, 178

specific capacity of ....

159

Flint River formation, occurrenee of......... 126

Flood, damage by, in $\mathrm{New}$ York State........233, 264-265

general features of, in New York State....... 233-234

Flood discharges, as sumptions and computations regarding............251-255 computation of by siopearea method..........253-255

effect of debris on..... 251

general features of .......246-249

maximum intensity of, mea surements of ........

264

records of, for streams in New York State....... 255-264

Florida Keys, piezometric surfecé 154

wells on, features of..... 154

Florida peninsula, areas of artesian flow in.....132-133,

pl. 10

artesian wells in, general features of . 157-160

chloride content of ground water in......162-164, pl. 16

geologic formations in, thickness, character, and water-bearing properties of.........

geology of, general

features of ..........119-121

reports on ................116-117

ground-water suppiles in; investigation of.....117-118

reports on ............116-117

plezometric surface in.... 146-147,

p1. 12

springs in....155-157, pls, 13-15 structure of ..........121, pl. 6 topography of ....................

Fort Thompson formation, age, thickness, character, and'waterbearing properties of.

Foster, M. D., analyses of water bj.............

122
G

Page

Genesee River, N. Y., flood discharges of.........

261

Geology, relation of, to occurrence of ground water..........66-71, 200

Georgetown iimestone, age of. 67 thickness and water-bearing properties of.... 67, 69

Gilboa Reservolr, N. Y., absorption of flood flow by...............

Gilchrist County, Fla., pressure heads and water levels in...... 191 records of wells in...... 167, 178 Gilmore Brook, N. Y., flood discharge of..........

Glades County, Fla., records of welis in.........167, 178

Glen Brook, N. Y., flood discharge of .........

Glen Creek, N. Y., flood discharges of ........ 261 slope-area reaches on....252-253,

Glen Creek drainage basin, pis. 24-26 N. 'Y., maximum intensity of discharge from.

Glendon limestone. See Vioksburg group.

Glen Rose limestone, age of. thickess and water-bearing properties of ..67, 68-69

Goliad sand, age of......... 200 character and water-bear-

ing properties of....200, 203

permeability of............ 212

quality of water in....... 215

wells obtaining water from. 220

Grass River, N. Y., flood discharge of......... 263

Great Chazy River, $\mathrm{N}$. $\mathrm{Y}$., flood discharge of'.... 263

Green Cove Springs, Fla., fluctuation of water

level in well in......

Ground water, chemical character of........ 48-49, 56, $104, i \dot{6} \dot{2}-i 64,213-216$

hardness of ............ 48-49, $56, \cdots 04,215-216$ movement of, in Kleberg County, Tex..........212-213 relation of geology to occurrence of.....66-71, 200 replenlshment of......... $47-48$, ..... $i 6 i-i 62,213$ waste of..... $\ddot{2} \dot{i}-\dot{2} \dot{1} \dot{1}$, pis 13,20 Guffins Bay, N. Y., flood discharge of unnamed brook near............ 262

Gulf series, occurrence, character, und waterbearing properties of

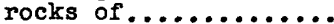

$\mathrm{H}$

Hamilton County, Fla., pressure heads and

water levels in....... 191 records of wells in.......167, 178 
Hawthom formation, age, thickmess, and character of .....122, 128-130

artesian pressure in..... 160 distribution of .......... 129 section of ..............129-130 water-bearing properties of .... $i 49.122,130,132,148$,

Hardee County, Fla., records of welis in..........167, 179

Hardness, amount of, in weil waters............ 48-49, $50,104,215-216$

Harrisburg Hollow, N.'Y., flood discharges of...

260

Hendry County, Fla., pressure heads and water levels in............ records of weils in.......i67, 179 specific capacity of well in .......... 159

Hermando County, Fia.., area of artesion flow in...

plezometric surface in... i49, 152 pressure heads and water levels in........... 191 records of weils in...i67-i68, 179 Highlands County, Fla., records of wells in..168, 179

Hillsborough County, Fla., area of artesian fiow in................ artesian conditions in.... piezometric surface in.... pressure heads and water levels in.............

records of weils in... $168,179-180$ Homosassa Spring, Fla., discharge of ..........

Hoosic River, Mass. $-\mathrm{N}, \mathrm{Y}_{\text {. }}$ flood discharges of ...

256

Homell, N. Y., flood conditions at..pls. 32, 35, 37, 38

Horse Creek, N. Y., flood discharge of.........

Hudson River, N. Y., fiood discharges of.........

262

Hudson River Basin, fïood discharges in.........

Hunter Spring, Fla., discharge and temperature of.................

\section{I}

Independence River, N. Y., flood di scharge of...

Indian River, N. Y., flood discharge of.........

Indian River County, Fla., records of weíls in..168, 180

Irrigation, history of, in Kleberg County, Tex...

use of artesian water for, in San Antonio area, Tex.............88-89, 90

Itchatuckne Springs, Fla., discharge of..........

Ithace, N. Y., destiuction by flood ln.......... pl. 33

$\mathrm{J}$

Jacksonville limestone, inclusion of, in Hawthom formation....
Jacksonville, Fla. loss of

Page artesian head in wells in............

Jetting outfit, operation of ...........15, 31, pl. 3

Johnson, B. $\dot{L}_{.}$, and Stephenson, L. W.,

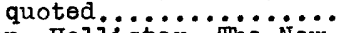

Johnson, Holifster. The New

York State flood of July 1935.233-268, pls. 22-38

Juniper Spring Creok, Fla., discharge and tempereture of ..............

$\mathrm{K}$

Kanona, N. Y., flood damage at................. pl. 34

Kayaderosseras Creok, N. $\mathrm{Y}$., flood discharge of....

256

Key Largo limestone, age. thickness, charactér, and water-bearing properties of .............

122

Kinderhook Creok, ${ }_{\mathrm{N}}, \mathrm{Y}_{\text {. }}$ flood discharge of .... 257

Kingsville, Tex., logs of wells near..........204, 208

annual precipitation at... 198

Kissengen Spring, Fla., discharge of ........ 156

Kleberg County, Tex. analyses of water from. 214

artesian area in..199-200, pl. 17 ground-water development in, history of ........198-199

investigation of groundwater resources of, outline of ...........197-198

purpose of ..............199-20c occurrence of salt water in water-bearing formations of........ 201 surface features of ........ 198 utilization of groundwater supplies in. ... 208-209 waste of water in........ 218

water level measurements pls. 19,20

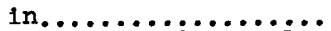

Knobbs Creek, N. C., analyses of water of ......

200

chloride content of water of, relation between rainfall deficiency

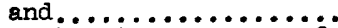
tide dam on, features of $.5, p l .2$

leakage of salt water beneath............ 8-9

treatment of water of, to remove color.........

Koch, J., et al., log of

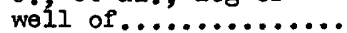

\section{I}

La Canada Valley, Cal1f, flood in.............

Iackawanna Railroad, flood conditions on, near Bath, N. Y........... pl. 32 Lagarto clay, age of........ 200 character and water-bearing properties of....200, 203 
Lake County, Fla., mineralized'water in. pressure heads and water levels in.............

records of weils in......... i68, 180

Lake George, N. Y., flood discharge of .........

Lake Ontario, flood discharges of streams tributary to........261-262

Laureles ranch, Tex... iogs of wells at...........204-208 records of wells at..226, 231-232

Lee County, Fla., records of weli's in.....168-169, 180-181

Lehigh Valley Railroad, washout of roadbed of. pl. 31

Leona formation, age and thickness of..........

water-bearing properties of ..............6, 71

Levy County, Fia... piezometric surface in..... 152

pressure heads and water levels in........... 191 records of weils in.......ib9, 181

Lissie formation, age of.... character and water-bearing properties of.....201, 200 , $\begin{array}{ll}\text { permeability of .......... } & 212 \\ \text { wells obtaining water from. } & 220\end{array}$

Iittle Beaver KIII, N. Y., flood discharge of....

Little Tonawanda Creek, N. Y., flood discharge of ................

Livingston, Penn, and Bridges, T. W., Ground-water resources of Kleberg County, Tex......197-232, pls. 17-21

Sayre, A. N., and White, W. N. , Wáter resources of the Edwards limestone in the San Antonio a rea, Tex.....59-113,

Lohman, K. W., quoted....... pl. $\begin{array}{r}5 \\ 15\end{array}$

Lohman, S. W., Geology and ground-water resources of the Elizabeth City area, N. C.....I-57, pls. 1-4

Lohr, E. W., chemical analyses of water by. $5{ }^{25}, 56,57$

Luther, R. W., chemical analyses of water by..

\section{M}

Manatee County, Fla, area of artesian fiow in... artesian conditions in.... loss of artesian head in wells in.............

mineralized water in....... pressure heads and water levels in............191-192 records of weils in........ i69-170,

Manatee Rlver marl, inclu181-182 sion of, in Hawthom

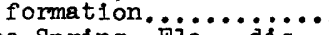
Manatee Spring, $\mathrm{F}$ ia., discharge of ...........
Marlanna limestone, occurrence of........ 126

Marion County, Fla., area of artesian flow in......

mineralized water in......

plezometric surface in.... 151

pressure heads and water

levels in............192-193

records of weils in...imo, 132-183

Martin County, Fla., pressure heads and water

levels in............ 193

records of weils in........i70, 183

Meads Creek, N. Y., flood discharge of..........

Medina County, Tex......... map of part of, showing geology and artesian conditions........... pl. 5

Melbourne bone bed, age, thickness and charac-

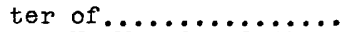

Meredith, N. $\ddot{Y}^{\prime}$ flood discharge of unnamed brook near...........

Meridale, N. Y., riood dischárge of unnamed brook near...........

Merrill Creek, N. discharge of.........

Mlami oolite, age, thickness, character, and water-bearing properties of............

Midway group, age and thickness of beds of.......

Mlocene beds, occurrence, character, and waterbearing properties of $\begin{array}{r}122, \\ 127-130\end{array}$

Mlocene (?) beds, occurrence of .......200, 203

Mohawk River, N. Y., fiood discharges of........

Monroe County, Fla., plezometric surface in..... 154

records of wells in.....ito, 183

Moose River, N. Y., flood discharge of......... 262

Midale Branch of, fiood discharges of.........

Mossom, Stuart, Cooke, $\mathrm{C}$. W. , and, quoted........119-120

Mount Selman formation, age

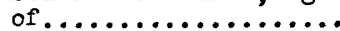

occurrence of

Myers, $N$. $Y$., flood on Salmon' Creek at....... pl. 23

N

Nassau County, Fla., area of artesian flow' in...... arteslan pressure in

Hawthorm formation in. 160

plezometric surface in....150-151 pressure heads and water levels in............ 193

records of weiis in........itr, 183

Navarro group, age, thickness, and water-bearing properties of beds of .............

Ne1l Creek, N. Y.., fiood discharge of......... 
Neversink River, N. Y., flood discharge of:...

New York Central Rallroad, destruction of high bridge of, at Watkins Glen, N. Y............ pl. 31

New York State, flood damage

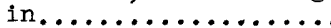
$264-265, \mathrm{pls}, 23,30$

flood-discharge determinations in, map showing

location of .......... pl. 29

1sohyetal map of .......... p1. 22 Norfolk Southern Raijroad well, driller's log of.

North Carolina State Normal School wells, driller's $\log$ of ...........

Norwich, N. Y., flood damages near......pls. 30, 34

Oak Grove sand. See Alum Bluff group.

Oaks Creek, N. Y., flood discharge of ..........

ocala limestone, age, thickness, and character of 122 ,

artesian pressure in....135, 160 artesian water in, occurrence of'........ 132

exposures of...........pls, 7, 8 relation of, to piezometric surface....... 146-147

water-bearing properties of ............. 122 ,

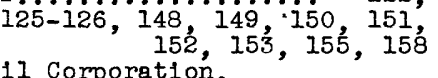

Ocala 011 Corporation, cuttings from well of. Okeechobee County, Fla.,
pressure heads and water levels in.......

record of well in......... irl, 184

Oligocene limestone, possible occurrence of ....122, 126 Onelda River, N. Y., flood discharge of.........

Orange County, Fla., pressure heads and water levels in ...........193-195

records of weils in.......171-172,

surface drainage into $184-185$ wells in.........161-162

osceola County, Fì... a rea of artesian fiow in.

records of wells in .....ing, 133

oswegatchie River, N. $\mathrm{Y}$. flood discharge of....

East Branch of, flood discharges of .........

West Branch of, flood discharge of.........

oswego Rlver, N. Y., flood discharge of .........

Otselic River, N. $\mathrm{y}_{\text {., flood }}$ discharge of..........

ouleout Creek, N. $\dot{Y}$., fïood discharge of .........

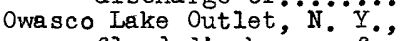
flood discharge of....

Owego Creek, N. Y., flood discharge of..........
Oxford, N. Y., flood

Page damage near.......... pl. 30

\section{P}

Palm Beach County, Fla. records of wells in..172, 185 speciflc capacity of wells in........... 159

Pamlico formation, age of... 17

Pamlico terrace, altitude of. Il

Pasco County, Fia., area of artesian flow in......

133

plezometric surface in.... pressure heads and water levels in........... 195

records of weilis in ..i72, 185-186

Pasquotank County, N. C., geology of .......... 13

location and popuiation of
surface features of....... 10-11

Pasquotank River, N. C., analyses of water of..

mouth of ............. 4-5

Permeablitiy, coefficient of. $\quad 212$

Plezometric surface, definition and general features of ..........146-147

map of Florida peninsuia, showing............. pl, 12

relation of a reas of highly minerallzed

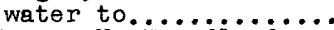

Pine Creek, N. Y., flood discharge of .........

Pinellas County, Fia., records of weli's in..172, 186

Ple1stocene beds, occurrence, character, and water-bearing properties of .......67, 200-203

Pllocene beds, occurrence, character, and waterbearing properties of . $131,200-203$

Pllocene (?) beds, age and thlckness of ..........

Poe Spring, Fla., discharge of .............. 156

Poesten Kili, $\ddot{N}_{\text {. }} \ddot{Y}_{.}$, fiood discharge of.........

Polk County, Fla, area of artesian flow in......

plezometric surface in....

pressure heads and water levels in........... 195 records of weils in..ipizir3, 186 specific capacity of wells

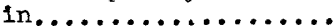

Ponce de Leon Spring, Fï.., discharge and temperature of ........

\section{Poultney River, Vt., fiood} discharge of..........

Princess Anne formation, age of .............

Princess Anne terrace, features of ...........

Purdy Creek, N. Y., fiood discharge of..........

Putnam County, Fla., mineralized wáter in.162, 163

plezometric surface in....149-150 pressure heads and water levels in............. records of weils in.......i73, 187 
R

Rainbow Spring, Fla., discharge and

temperature of ........

155

Rainfall, fluctuations of

artesian head caused

by...............136-138

in New York, causes of 142,143

unusua 1............235-236

map showing........... pl, 22

mi scellaneous measure-

ments of............244-245

records of, comparison

of ............236-237

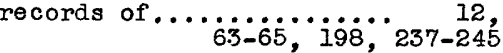

Raquette River, N. Y., flood discharge of ..........

263

Read, W. T., analyses of water by............

Recent beds, occurrence character, and waterbearing properties of.

Reservolrs, absorption of flood flow by.........

Reynosa formation. See Goliad sand.

Richelleu River, $\dot{N}$. $Y$., flood discharge of....

263

River stages, changes in, fluctuations in artesian head due to..14I-142

Riviera, Tex., chemical character of water from wells near. .....215-216

Rock Spring, Fla., discharge and temperature of....

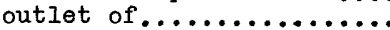

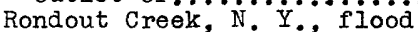
discharges of ........

\section{S}

Sacandaga River, N. Y., flood discharges' of...

East Branch of, flood discharge of ......

Sage Brook, N. Y., flood discharge of.........

St. Augustine, Fla., pressure head in weIl at.

St. Johns County, Fla. mineralized water in.

pressure heads and water levels in............

256

256

259

135

162

等 flood discharges of' streams tributary to..

263

St. Lucie County, Fla., pressure heads and water levels in.......

records of wells in.......i73, 188

St. Regis River, N. Y., flood discharge of ....

263

salado Creek, flowing weils near, discharge of .89,90, 109

Salado Creek Springs, discharge of ........... 85-86

Salado Water Co.'s well, discharge of.........89, 109

Salmon Creek, N. Y.., filood discharge of..........

view of flood on......... pl, 23
Salmon River, N. Y., flood discharge of .........

Page

Salt Spring, Fla., discharge

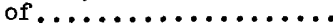

Salt springs, occurrence of, In Florida...........

Salt water, contamination of wells by, problem of..

leaks of, in wells, method of locating........ 216-218,

occurrence of, in waterbearing formations of Coastal Plain....162-164, 201

San Antonio, Tex., average quantities of water used by..............

San Antonio area, Tex., climate of .......... 63-65

farm and ranch water supplies in......... 89, 90

fluctuations of artesian pressure in......98-100, 109

geology of ...........67, 71-72 ground-water in, investigations of .......... 60-62

outlook for future use of ...............104-107

utilization of, for public supplies....... springs and welis in, total discharge from.. 89-9I

topography of ........... 65-66 water levels in observation wells in.........110-113

San Antonio River, Tex., discharge of ..........

108

San Antonio Springs, Tex. discharge of, fluctuations in............

discharge of, in $1934 \ldots . . .86,90$

Sand, recent, occurrence and water-bearing properties of, in Kleberg County, Tex.....200,201, 215

San Pedro Creek, Tex., ground-water discharge

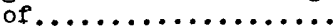

San Pedro Springs, Tex., discharge of, fluctuations in.............

discharge of, in $1934 \ldots . .86,90$

Santa Gertrudis ranch, Tex., artesian well at, flow of ................ 199

logs of weils at...........203-204 records of wells at..221, 226-227

Saranac River, N. Y., flood discharge of .........

263

Sarasota County, Fla., area of artesian flow in...

artesian conditions in....

loss of artesian head in wells in............

mineralized water in ..... 163

records of wells in..173-174, 188 Saw K1ll, N. Y., flood discharges of ....... 257

Sawyers Creek, N. C.. analyses of water of..

Sayre, A. N. Livingston, Penn, and White, W. N., Water resources of the Edwards limestone in the San Antonio area Tex...........59-113, pl. 5 
Schoharle Creek, N. Y., flood discharges of...

Schroon River, N. Y., flood discharge of .........

Seminole County, Fia... ioss of artesian head in wells in............. mineralized water in...... pressure heads and water levols in ............ records of weils in........ir4, 188 Seminole Spring, Fla., discharge of $\ldots \ldots \ldots . .$.

Shackham Brook, N. ì., fiood discharge of ..........

Shoal RIver formation. See Alum Bluff group.

S1lver Glen Spring, Fia., discharge and temperature of ..............

Silver Springs, Fia., discharge of.......151, 155, 157

temperature of ........... 155

view of ................ pl. 13

Six Mile Creok, $\mathbb{N}_{\text {. }}$., flood discharges of .........

Slope-area method, use of, for computing flood' di scharge...........253-255

Smithville Flats, $\dot{\mathrm{N}} \cdot \ddot{\mathrm{Y}}$. flood damáge at....... pl. 38

Softwater Creek, N. Y.., drainage basin of, maximum intensity of dising

flood discharge of ........ Sopchoppy limestone, inclusion of, in Hawthom

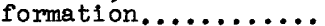

Steele Brook, N. Y... fiood discharge of..........

stephens Creek, N. Y. $_{.}$fiood discharge of ..........

stephenson, L. W., and Johnson, $B_{0}$ L., quoted.

Stone M111s, N. Y., flood discharges of unnamed brooks near..........

Stony Brook, N. Y., flood discharge of ..........

Stony Creek, N. Y. See West Stony Creek: East Stony Creek.

Stringfield, V. T., Artesian water in the Florida peninsula..115-195, pls, 6-16

Strongs Brook, N. Y., flood discharge of.........

261

Tat

T
flood discharges of... 262
Taughannock Falls state

$$
\text { Park, N. Y., flood }
$$$$
\text { damaǵe in.......... pl. } 33
$$

Taylor marl, age, thickmess, and water-bearing

264

261

129

258

260

22

262

261

Sulphur Spring, Fla. $68,121,200$, pis. 5,66 discharge and temperature of ...........

Sumter County, Fla., pressure heads and water levels in........... 195 records of weils in........i74, 189

Sun City, Fla., artesian conditions near......

161

Susquehanna River, N, $\mathrm{Y}_{.}-$ $\mathrm{Pa}$., flood discharges

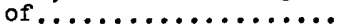

at Binghamton, $\ddot{\mathrm{N}}, \dot{\mathrm{Y}}^{\prime} \cdot$ maximum stages of....267, properties of .........

Tenmile Creek, N. Y.. fiöd

discharge of ......... 260

N. Y.-Pa., flood

discharges of streams

ins and floods in ....265-268

sure heads and water

levels in 195

records of weils in........i74, 189

Suwannee River area, Fla., plezometric surface'

in................

oochee Spring, Fla.,

Tides, fíctuations of artesian head due to.. 141

Tioga River, N. Y., flood discharges of........

Tloughnioga Rlver, $\dot{\mathrm{N}}_{\text {. }} \dot{\mathrm{Y}}_{\text {. }}$ flood discharges of...

Titusville, Fla., salt bed in well at. .........

122

132

127

pl. 9 i27-128

Townsend, N. Y., slope-area reach on Glen Creek near........252-253, p1. 24

Travis Peak formation,

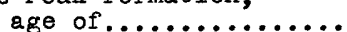

thickness and water-bearing properties of.... 67, 68

\section{$\mathrm{U}$}

Unadilla River, N. Y., flood discharges of...

Union County, Fla., pressure heads and water levels in................ 195

records of weiis in........ it4, 189 Uvalde gravel, age, thickness, and watér-bearing properties of.....

\section{V}

V1cksburg group, formations

of ................ 126

volusia County, Fia.., ioss of artesian head in wells in............. 145

mineralized water in....... 162-163 plezometric surface in....151-152 
Volusia County, Fla., pressure heads' and water levels in....... Page records of wells 1 ........ i75, 189

\section{W}

Walkill River, N. Y., flood discharges of.......... Walloomsac River, vi... fiood discharge of ..........

Walnut clay, age, thickness, and water-bearing properties of .........

Water-bearing beds in Elizabeth City area, N. C., at intermediáte depths, distribution and thickness of......

at intermediate depths, physical properties of 26-27 shallow, distribution and thickness of ......... method of investigation of $\ldots \ldots \ldots \ldots \ldots \ldots$ physical properties of.

Water-level recorder, view of ................ pl, 11

Water-pressure recorder, view of ............. pl. 11

Water table in Eilzabeth City area, N. C. altitude and shape of $42-43$ fluctuations of .....43-45, pl. 4 Watkins Glen, N. $\mathrm{Y}$. destruction of New York Central Ra1lroad bridge at........... pl. 31 slope-area reach on Glen Creek near...253, pls. 25, 26 Weekewachee Spring, Fla.,

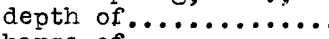

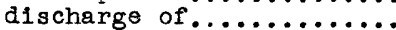

view of.................. pl. 14

Wek1va Spring, Levy County, Fla., discharge of....

Orange county, Fla, discharge and temperature of.

Wells in Elizabeth City area, N. C., analyses of water of ...........
Wells in Elizabeth City area, N. C., depth to water levels in....... 55 gravel-wall............32, 40-42 head of woter in......... 27

logs of ......... $i 4, i \dddot{i}-\dot{2} i, 29-30$ quality of water of..28-29, 48-49 records of ............. 51-54 yield of ........24, $27-28,45-47$ Wells in Fiorida, pressure heads and water, levels

in.................190-195

records of ..............165-189

use of, for surface dránage............161-162

Wells in Kleberg County, Tex., analyses of water from...........

location of sait-water leaks in.200, 216-218, pl. 18

logs of ...............203-208 methods of driliing.......219-220 records of .............220-232 water levels in observation...............210-212

Wells. See also Artesian weIIs.

West Canada Creek, N. Y. flood discharges of...

West Stony Croek, N. Y. flood discharge of....

White, W. N., Livingston, Penn, Sayre, A. N., and, Water resourcés of the Edwards limestone in the San Antonio area, Tex.....59-113,

White Spring, Fla., discharge of........... 156

Wilcox group, age and thickness of..............

water-bearing properties of beds of .........67, 70 Willet Greek, N. Y... fiood discharge of ......... 259 Williams, K. T., chemicai anályses of water by. 56,57 ,

Wright Brook, N. Y., flood discharge of.......... 